\title{
HIBRIDAÇÃO SOMÁTICA EM CITROS COM ÊNFASE AO MELHORAMENTO DE PORTA-ENXERTOS
}

\section{MARIA ANGÉLICA PEREIRA DE CARVALHO COSTA}

Engenheira Agrônoma

Orientador: Prof. Dr. Francisco de Assis Alves Mourão Filho

\begin{abstract}
Tese apresentada à Escola Superior de Agricultura "Luiz de Queiroz", Universidade de São Paulo, para obtenção do título de Doutor em Agronomia, Área de Concentração:

Fitotecnia
\end{abstract}

\author{
PIRACICABA \\ Estado de São Paulo - Brasil \\ Abril - 2001
}


Dados Internacionais de Catalogação na Publicação (CIP)

DIVISĀO DE BIBLIOTECA E DOCUMENTAÇĀO - Campus "Luĩz de Oueiroz"/USP

Costa, Maria Angélica Pereira de Carvalho

Hibridação somática em citros com ênfase ao melhoramento de porta-enxertos / Maria

Angélica Pereira de Carvalho Costa. - - Piracicaba, 2001.

122 p. : il.

Tese (doutorado) - Escola Superior de Agricultura Luiz de Queirọz, 2001.

Bibliografia.

1. Atividade enzimática 2. Citologia vegetal 3. Cultura de protoplasto 4. Fruta cítrica 5. Hibridação somática 6 . Marcador genético 7. Melhoramento genético vegetal 8. Plaqueta 9. Porta-enxerto I. Título

CDD 634.3

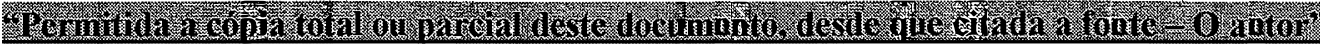


Aquele que perde dinheiro, perde muito;

Aquele que perde um amigo, perde mais;

Aquele que perde a Fé, perde tudo. 


\section{DEDICO}

A Onildo, Juliana e João, pelos momentos que não Ihes pude dar atenção;

Aos meus pais, irmãos, cunhados, cunhadas e sobrinhos pelo carinho e compreensão;

A Dr. Onildo e Filomena pelo apoio constante. 


\section{AGRADECIMENTOS}

A Deus, pela luz que nos guia

Ao Prof. Dr. Francisco de Assis A. Mourão Filho, pela orientação, disponibilidade e atenção durante a realização da pesquisa.

À Profa. Dra. Beatriz M. Januzzi Mendes, do Laboratório de Biotecnologia Vegetal do CENA/USP, pelas sugestões e acompanhamento do trabalho.

À Profa. Dra. Adriana P. M. Rodriguez, do Laboratório de Biotecnologia Vegetal do CENA/USP, pela contribuição nas análises histológicas.

Ao Prof. João Aleixo, do Departamento de Produção Vegetal, pelas informações recebidas.

Ao Prof. Dr. Luis Eduardo Aranha Camargo, do Departamento de Entomologia, Fitopatologia e Zoologia Agrícola, pelo apoio nas análises moleculares.

Aos colegas, Márcio Tomaz, Vagner Benedito, Paulo Celso de Mello Farias, Liliane C. Libório Stipp, Adriana P. Rissi, Márcia Cristina Calixto Alessandra Pavan, João Carlos Azevedo, pelo companheirismo, amizade e incentivo.

A Carlos Alberto de Oliveira, pelo prestimoso auxílio nas contagens de cromossomo.

A Maria Célia Ridrigues, Elizabete A. S. São João, Maria Ivete Monteiro de Almeida, Elena Rodrigues Camargo e Maria Clarice Bonifácio Martins pelo apoio e solidariedade.

A David Ulrich e Aparecido Donizete Serrano, pelos auxílios prestados. 
À Marilia Henyei, bibliotecária chefa (CENA/USP), pela revisão das referências bibliográficas.

À Biblioteca do CENA/USP e a Biblioteca Central da ESALQ/USP.

Ao Centro de Citricultura "Sylvio Moreira", pela atenção e fornecimento de frutos utilizados no träbalho.

Aos amigos Pedro Louça, Edna Louça, Herika Louça, Sandra Louça e Marcelo Louça, pelo acolhimento e incentivo.

Aos colegas, Léa Araújo de Carvalho, Carlos Augusto Pereira Elvis Vieira Lima, Estevão Leite, José Fernandes Melo Filho, Clóvis Pereira Peixoto, Carlos Alfredo Lopes de Carvalho, Carlos Estevão Leite Cardoso, Manuel Oliveira, juntamente com todos seus familiares, pelo companheirismo.

Agradeço de modo especial a meu irmão Weliton Antônio Bastos de Almeida, pelo exemplo de lealdade e incentivo.

Aos colegas Rodrigo R. Martiello, Célia C. Mauva e Daniela Truffie pelo constante apoio e acompanhamento nas análises moleculares.

Aos colegas de curso, pela convivência e companheirismo.

À Escola de Agronomia da UFBA, pela oportunidade de realizar 0 curso de doutorado.

Aos colegas do Departamento de Fitotecnia da EAUFBA, pelo apoio e incentivo.

A equipe da empresa Cópias \& Companhia pelo apoio na confecção da tese;

À CAPES, pela concessão da bolsa de doutorado.

À FAPESP e ao FUNDECITRUS, pelo apoio financeiro que permitiu a condução deste trabalho.

A todos aqueles que direta ou indiretamente contribuiram para a elaboração deste trabalho, meus mais sinceros agradecimentos. 


\section{SUMÁRIO}

LISTA DE FIGURAS

Página

LISTA DE TABELAS

ix

$x i$

RESUMO

xii

SUMMARY

xiv

1 INTRODUÇÃO

2 REVISÃO DE LITERATURA

2.1 Importância sócio-econômica da citricultura ...................... 3

2.2 Principais problemas da cultura ................................... 4

2.3 Melhoramento de citros no Brasil................................... 7

2.4 Objetivos do melhoramento................................... 10

2.5 Dificuldades dos programas de melhoramento................... 11

2.6 Melhoramento utilizando-se técnicas biotecnológicas.......... 14

2.6.1 Cultura de calos embriogênicos............................... 15

2.6.2 Cultura de suspensões celulares.............................. 18

2.6.3 Protoplastos: isolamento, cultivo e regeneração plantas ... 20

2.6.4 Hibridação somática como recurso ao melhoramento citros............................................................. 26

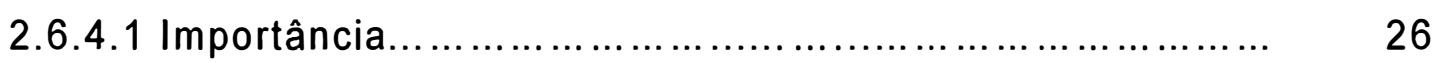

2.6.4.2 Técnicas de fusão de protoplastos e obtenção de

híbridos somáticos.

2.6.4.3 Efeito da ploidia nas células da epiderme dos híbridos somáticos. 
2.6.4.4 Confirmação de híbridos somáticos

3 MATERIAL E MÉTODOS ........................................... 37

3.1 Material vegetal............................................... 37

3.1.2 Cultivo de calos embriogênicos............................... $\quad 37$

3.1. 3 Cultivo de plantas in vitro, a partir de sementes............. 38

3.2 Eficiência de isolamento de protoplastos de calos embriogênicos, em diferentes soluções enzimáticas.......... 38

3.2.1 Purificação .......................................................... $\quad 40$

3.2.2 Cultivo de protoplastos: Efeito de diferentes densidades de plaqueamento.

3.3 Embriogênese somática: Cultura de protọplastos, indução a embriogênese e regeneração de plantas........................... 41

3.4 Hibridação somática................................................. $\quad 42$

3.4.1 Fusão e plaqueamento dos protoplastos........................ 44

3.4.2 Aclimatização................................................. 44

3.5 Confirmação da hibridação.......................................... $\quad 45$

3.5.1 Identificação de plantas poliplóides........................... 45

3.5.1.1 Análise estomática .......................................... 45

3.5.1.2 Análise citológicas.......................................... 46

3.5.2 Análise morfológica foliar.................................... $\quad 47$

3.5.3 Análise de DNA por marcadores RAPD....................... 47

3.5.3.1 Extração de DNA.................................................. 47

3.5.3.2 Quantificação do DNA......................................... 48

3.5.3.3 Seleção de "primers" para utilização nas reações de RAPD ......................................................... 48

3.5.3.4 Reação de amplificação do DNA............................... 49

3.5.3.5 Eletroforese e análise ........................................ 49 
4 RESULTADOS E DISCUSSÃO

4.1 Isolamento de protoplastos de calos embriogênicos, em

diversas soluções enzimáticas.

4.2 Cultivo de protoplastos.

4.3 Embriogênese somática: Cultura de protoplastos, indução a embriogênese e regeneração de plantas

4.4 Hibridação somática em citros....................................... 63

4.5 Aclimatização....................................................... 66

4.6 Confirmação da hibridação somática................................. 69

4.6.1 Efeito da ploidia nas células da epiderme foliar dos produtos de fusão de protoplastos

4.6.2 Análise de DNA genômico, por marcadores RAPD, citologia e morfologia foliar dos produtos de fusão de protoplastos

5 CONCLUSÕES 85

REFERÊNCIAS BIBLIOGRÁFICAS. 87 ANEXO 


\section{LISTA DE FIGURAS}

Página

1 Eficiência final de plaqueamento (\%), em função da densidade de cultivo $\left(\mathrm{n}^{\circ}\right.$ de protoplastos. $\left.\mathrm{mL}^{-1}\right), 11$ variedades cítricas.

2 Aspectos morfológicos dos embriões somáticos de laranjas doces desenvolvidas in vitro..........................................

3 Aspectos morfológicos dos embriões somáticos de tangerina 'Cleópatra' desenvolvidos in vitro.

4 Aspectos morfológicos dos embriões somáticos de limão 'Cravo' desenvolvidos in vitro.

5 Epidermes foliares abaxiais de plantas diplóides e do respectivo produto de fusão: tangerina 'Cleópatra' + limão 'Volkameriano.

6 Epidermes foliares abaxiais de plantas diplóides e do respectivo produto de fusão: Iaranja 'Valência Rohde Red' + limão 'Volkameriano'.

7 Epidermes foliares abaxiais de plantas diplóides e do respectivo produto de fusão: laranja 'Ruby Blood' + limão 'Volkameriano'.

8 Número médio de estômatos dos parentais diplóides e respectivos produtos de fusão de protoplasto......................

9 Tamanho médio de estômatos dos parentais diplóides e respectivos produtos de fusão de protoplastos....................

10 Análise de DNA genômico por marcadores RAPD, citologia e morfologia foliar dos produtos de fusão de tangerina 'Cleópatra' + limão 'Volkameriano'. 
11 Análise de DNA genômico por marcadores RAPD, citologia e morfologia foliar dos produtos de fusão de laranja 'Valência Rohde '+ limão 'Volkameriano'

12 Análise de DNA genômico por marcadores RAPD, citologia e morfologia foliar dos produtos de fusão de laranja 'Ruby Bood' + limão 'Volkameriano'

13 Análise de DNA genômico por marcadores RAPD, citologia e morfologia foliar dos produtos de fusão de limão 'Cravo' + tangerina 'Sunki'

14 Análise de DNA genômico por marcadores RAPD, citologia e morfologia foliar dos produtos de fusão de laranja 'Valência' cv. 63 + Fortullena obovata..................................... 


\section{LISTA DE TABELAS}

Página

1 Combinações envolvidas nos experimentos de hibridação somática

2 Número de protoplastos. $\mathrm{g}^{-1}$ de calo, em 11 variedades cíticas conforme solução enzimática

3 Indução da embriogênese somática $\left(n^{\circ}\right.$ de embriões.placa de Petri) nas linhagens de calo em 11 variedades cítricas, em diferentes densidades de plaqueamento

4 Número de plantas regeneradas, após 120 dias de cultivo, dos embriões somáticos em meio de germinação.................

5 Número total de embriões somáticos em meio de cultura EME, modificado pela adição de fontes de carbono elou reguladores vegetais em combinações de fusão de protoplastos envolvendo parentais embriogênicos de laranjas doces + tangerinas 'Poncãn' ou 'Mexerica Rio'.........

6 Plantas aclimatizadas e sobreviventes ao processo de aclimatização, 9 meses após fusão de protoplastos, de 5 combinações parentais 


\title{
HÍBRIDAÇÃO SOMÁTICA EM CITROS COM ÊNFASE A MELHORAMENTO DE PORTA-ENXERTOS
}

\author{
Autora: Maria Angélica Pereira de Carvalho Costa \\ Orientador: Prof. Dr. Francisco de Assis Alves Mourão Filho
}

\section{RESUMO}

- O Brasil é considerado o maior produtor mundial de citros, com uma área plantada superior a um milhão de hectares. No entanto, os pomares apresentam baixa produtividade (cerca de $2,0 \mathrm{~kg}$ por metro quadrado), causada por problemas fitossanitários e um número limitado de variedades copa e porta-enxerto. Programas de melhoramento genético, via hibridação sexual, visando introgredir genes de resistência a doenças e que venham melhorar a qualidade dos frutos têm sido conduzidos, porém, apresentam resultados modestos. Isso se deve às características reprodutivas impostas pela própria espécie. Uma alternativa para contornar essas barreiras é a hibridação somática, via fusão de protoplastos. Este trabalho de pesquisa teve como objetivo produzir híbridos somáticos a serem utilizados em programas de melhoramento de citros. Experimentos preliminares em linhagens de calos 
embriogênicos envolveram diferentes soluções enzimáticas e densidades de cultivo no isolamento de protoplastos e eficiência na densidade final de plaqueamento, respectivamente, para otimizar o protocolo de fusão de protoplastos. Paralelamente, buscou-se avaliar o efeito da ploidia nas células da epiderme foliar do produto de fusão de protoplastos. As variedades eleitas neste trabalho devem-se a complementaridade das características dos parentais. Experimentos de fusão de protoplastos foram realizados utilizando-se solução de polietilenoglicol (PEG). Microcolônias foram transferidas para meio de cultura MT semi-sólido suplementado com $500 \mathrm{mg} \cdot \mathrm{L}^{-1}$ de extrato de malte para indução da embriogênese somática. A confirmação da hibridação somática das plantas regeneradas e aclimatizadas foi realizada por meio de análises estomática e da morfologia foliar, contagem do número de cromossomos e por marcadores moleculares (RAPD). O número de protoplastos isolados e a eficiência final de plaqueamento variaram em função da densidade de cultivo e variedade estudada. Os híbridos somáticos desenvolvidos apresentam potencial para serem utilizados como porta-enxertos visando tolerância ao declínio nas combinações de tangerina 'Cleópatra' + limão 'Volkameriano', laranjas doces + limão 'Volkameriano' e limão 'Cravo'+ tangerina 'Sunki', bem como, serem incorporados em programas de melhoramento de copa e proporcionar a produção de frutos sem sementes como o híbrido de Iaranja 'Valência' cv. 63 + Fortunella obovata. 


\section{CITRUS SOMATIC HYBRIDIZATION WITH EMPHASIS TO ROOTSTOCK IMPROVEMENT}

Author: Maria Angélica Pereira de Carvalho Costa Advisor: Prof. Dr. Francisco de Assis Alves Mourão Filho

\section{SUMMARY}

Brazil is considered the world's greatest citrus producer, with a cultivated area exceeding one million hectares. However, the yield is low (about $2,0 \mathrm{~kg}$ for square meter), due to disease problems and a limited number of scion and rootstock varieties. Breeding programs, via sexual hybridization, with the aim of introgress disease resistance genes and to improve fruit quality, have been conducted, with modest results. Conventional citrus breeding has found several barries, incluing the reproductive biology of citrus (nucellar polyembryony, juvenility, incompatibility). An alternative overcome these barriers is somatic hybridization, via protoplast fusion. This research work had the objective produce somatic hybrids, to be used in citrus improvement programs. Preliminary experiments with embriogenic callus lives involved different enzymatic solutions and densities for protoplast isolation and platting efficiency, respectively, to optimize protoplast fusion protocol. The ploidy effect in somatic hybrid was also evaluated 
Varieties were selected for somatic hybridization based on theirs complementary horticultural traits. Protoplast fusion experiments were induced by chemical method, with polyethylene glycol (PEG) solution. Microcolonies were transfered to EME semi-solid MT additional 500 $\mathrm{mg} \cdot \mathrm{L}^{-1}$ malt extract for somatic embriogenesis. Somatic hibridization was confirmed by the analysis of stomatal and leaf morphology, chromosome count, and molecular analysis (RAPD). Regenerated somatic hybrids regenerated have potential to be used as tolerant rootstocks to blight ('Cleópatra' mandarin + 'Volkamer' lemon, sweet oranges + 'Volkamer' lemon, and 'Rangpur lime' + 'Sunki', mandarin). 'Valência' cv. 63 sweet orange + Forrtunella obovata may be incorporated scion improvement programs as a tetraploid pollen donors $4 x$ in $2 x$ crosses to produce triploid seedless varieties. 


\section{INTRODUÇÃO}

O Brasil é o maior produtor mundial de citros, com uma área plantada superior a um milhão de hectares e produção de 23.988.180 toneladas métricas, safra 1999/2000, seguido pelos Estados Unidos e pela China (FAO, 2001). No entanto, a expansão da cultura vem sendo limitada devido ao pequeno número de variedades copa e porta-enxerto (Amaro et al., 1991), somada aos problemas fitossanitários que causam diminuição na área de pomares em produção e desaceleração do ritmo de novos plantios (FNP Consultoria e Comércio, 2001).

Programas de melhoramento genético, via hibridação sexual, seleção de mutações espontâneas e indução de mutações visando à seleção de novas variedades mais produtivas, resistentes a pragas e doenças, bem como melhores adaptadas às condições abióticas, têm sido conduzidos, porém, com pouco sucesso, devido a aspectos da biologia reprodutiva inerente a cultura (Vardi, 1981; Grosser \& Gmitter Junior, 1990b; Pompeu Junior, 1991).

A partir da década de oitenta, com o avanço das técnicas de biotecnologia, a hibridação somática por fusão de protoplastos também passou a ser utilizada em programas de melhoramento de citros, superando as barreiras genéticas impostas à -hibridação sexual, possibilitando a obtenção de híbridos somáticos alotetraplóides, os quais combinam o genoma nuclear de ambos os parentais.(Grosser \& Gmitter Junior, 1990b). 
- Vários híbridos somáticos tếm sido desenvolvidos visando minimizar ou eliminar problemas de performance horticultural, contribuindo assim para expansão da citricultura. .

O principal objetivo deste trabalho foi a produção de híbridos somáticos interespecíficos para melhoramento de variedades portaenxerto, que combinem variedades com características complementares, usando a técnica de fusão química de protoplastos. Outros objetivos deste trabalho de pesquisa foram:

a) Produção de híbridos somáticos interespecíficos entre variedades de laranjas doces e tangerinas, para serem utilizados como parental tetraplóide em programas de melhoramento de copa;

b) Desenvolver híbridos somáticos entre Citrus e gêneros correlatos, que possuam boas características horticulturais a serem incorporadas no "pool" gênico dos Citrus;

c) Estudar o efeito de soluções enzimáticas no isolamento de protoplastos de citros;

d) Avaliar diferentes densidades de plaqueamento no cultivo de protoplastos de citros;

e) Verificar o efeito da ploidia nas células da epiderme foliar de híbridos somáticos. 


\section{REVISÃO DE LITERATURA}

\subsection{Importância sócio-econômica da citricultura}

A cultura dos citros possui grande potencial econômico no âmbito nacional e internacional. A produção mundial de citros foi de 98.288.123 toneladas métricas, na safra 1999/2000, superando as culturas da banana, uva e maçã, tendo o Brasil contribuído com $24 \%$ da produção (FAO, 2001).

A importância do Brasil como produtor de citros está embasada principalmente na laranja, cuja produção foi estimada para safra 1999/2000 em 22.772.180 toneladas métricas, distribuídas nas regiões Norte $(1,63 \%)$; Nordeste $(9,87 \%)$; Sudeste $(83,34 \%)$; Sul $(4,42 \%)$ e Centro-Oeste $(0,74 \%)$. Destas regiões, 0 Estado de São Paulo é o principal produtor, detendo $80 \%$ do total produzido no pais, seguido de Sergipe, Bahia e Minas Gerais (FNP Consultoria e Comércio, 2001; FAO, 2001).

Os cultivares copa mais plantados no Estado de São Paulo, em 1998, foram laranja 'Pêra' (38.02\%), seguido das laranjas 'Natal' (25.56\%), 'Valência' (17.32\%) e 'Hamlin' (6.79\%). Além das laranjas, também são cultivadas tangerinas (5.51\%) e limões $(2.90 \%)$. Dentre as tangerinas, destaca-se a 'Poncãn' com $58 \%$ das árvores, ficando 0 restante dividido entre 'Cravo', 'Mexerica' e tangor 'Murcote' com participações quase iguais. Entre os limões, a lima ácida 'Tahiti' representa quase $90 \%$ das plantas (Fundecitrus, 2001). 
Em termos de capacitação de divisas as exportações cítricas (suco concentrado, laranja fresca de mesa e óleo essencial) chegaram a US $\$ 1,35$ bilhão em 1999, correspondendo a $2,8 \%$ das exportações totais do Brasil e $9,9 \%$ das exportações dos agronegócios do país. O suco de laranja concentrado foi o principal produto de exportação para o Estado de São Paulo (US $\$ 1,23$ bilhão), superando o açúcar, café e outros produtos de grande importância econômica para o estado, gerando emprego para $400 \mathrm{mil}$ trabalhadores (Neves, 2000). Outrossim, pode-se considerar o mercado interno brasileiro como grande mercado a ser conquistado, consolidando a citricultura como importante segmento na agroindústria.

\subsection{Principais problemas da cultura}

A produção de citros no Brasil sempre mereceu destaque desde 0 início do século $X X$, mas tornou-se atividade agrícola de grande importância para o Brasil a partir da década de 60 , quando o principal destino da produção tornou-se a industrialização. Embora o Brasil ocupe posição de liderança na produção de laranja, a produtividade dos pomares ainda é reduzida comparada aos Estados Unidos (FAO, 2001).

Diversos fatores devem ser apontados como responsáveis pelos baixos índices de produtividade nos pomares cítricos comerciais de São Paulo e de outros Estados brasileiros destacando-se a susceptibilidade das variedades utilizadas a inúmeras pragas e doenças que, encontrando condições favoráveis ao seu desenvolvimento, são capazes de causar danos à produção e qualidade das frutas cítricas. Dependendo da intensidade do ataque nas plantas, pode torná-las improdutivas ou levar à sua erradicação. Outro aspecto a ser considerado refere-se ao limitado número de variedades copa e porta-enxerto (Amaro et al., 1991). 
Vários são os problemas de ordem fitossanitária na cultura, principalmente as doenças causadas por bactérias, fungos e vírus. Das doenças que ocorrem nos citros, quatro se destacam: o cancro cítrico, a clorose variegada dos citros, gomose e tristeza.

O cancro cítrico e a clorose variegada dos citros (CVC) ou Amarelinho são doenças bacterianas causadas por Xanthomonas axonopodis pv. citri e Xylella fastidiosa, respectivamente, que podem ser disseminadas principalmente por mudas e frutos. Xanthomonas axonopodis $p v$. citri afeta todas as variedades cítricas, sendo as variedades de limões as mais suscetíveis, provocando lesões nas folhas, frutos e ramos e, consequentemente, a queda da produção. Altamente contagiosa, ela é resistente e consegue sobreviver em vários ambientes por mais de nove meses. Como não existe método curativo para doença, a única forma de eliminá-la é por meio de erradicação do material contaminado (Rossetti, 1991). Segundo o censo do Fundecitus (2001), cerca de 299.856 plantas em 132 municípios do Estado de São Paulo estavam contaminadas com esta doença, sendo erradicadas 194.333 plantas.

Quanto a clorose variegada dos citros, esta é uma doença restrita ao xilema da planta, que provoca entupimento dos vasos. Os primeiros sintomas são vistos nas folhas, passando posteriormente para os frutos e acabam afetando toda a planta. A produção do pomar afetado pela doença é muito pequena. Seus frutos ficam duros e amadurecem precocemente. A bactéria é transmitida e disseminada nos pomares por insetos vetores, cigarrinhas, bem como por mudas contaminadas. As regiões Norte e Nordeste do Estado de São Paulo, em 2000, foram as mais atacadas com $52,62 \%$ e $43,44 \%$, respectivamente, de incidência da doença. No entanto, sabe-se que em todas regiões citrícolas a CVC está presente (Fundecitrus, 2001). Todas as variedades de laranjas, exceto tangerinas e limões são afetadas pela bactéria (Rossetti, 1991). Como 
ainda não há forma específica de combate a Xylella fastidiosa, os citricultores devem adquirir mudas que estejam livres da doença.

A gomose é causada por fungo do gênero Phytophthora. Esta doença comumente se manifesta no colo da planta, podendo expandir-se para as raizes principais até 20 ou $30 \mathrm{~cm}$ abaixo do solo e para cima do tronco. Portanto, quando toda a periferia do tronco é atingida a planta morre por estrangulamento devido ao ataque do câmbio. Entre os porta enxertos o Poncirus trifoliata, citrumelo 'Swingle' e a laranja azeda são altamente resistentes. A tangerina 'Cleópatra' e o limão 'Cravo' são mais ou menos suscetíveis; a laranja 'Caipira' é altamente suscetível a doença. No caso da utilização destes porta-enxertos, a prevenção a gomose consiste em evitar o plantio em solos úmidos, no entanto deve-se optar por variedades resistentes à referida doença (Amorin, 1997).

A tristeza é uma doença virótica, causada por Closteriovirus, cuja transmissão é feita pela enxertia e também por insetos vetores. $O$ vírus bloqueia os vasos condutores da seiva no ponto de união das combinações suscetiveis, determinando a morte das radicelas por inanição. As folhas das plantas infectadas amarelecem e caem, seguido do secamento dos ramos. Admiti-se que o vírus da tristeza ocorre em todas as plantas cítricas do Brasil, sendo o cultivo dos citros possivel graças à existência de variedades tolerantes ou resistentes, tais como 0 limão 'Cravo', 'Rugoso' e tangerinas. Porta-enxerto de laranja azeda é intolerante a tristeza, fato que limita uma ampla utilização desta variedade em plantios comerciais, apesar de sua excelente qualidade (Rossetti, 1991; Salibe, 1991).

Outro problema de importância econômica para citricultura é o Declínio, que vem afetando anualmente $5 \%$ das plantas nos pomares paulistas. Esta anormalidade geralmente ocorre em planta adulta, após as primeiras produções, afetando inicialmente partes da árvore, deixando-a sem folhas e com uma coloração verde opaco. Os frutos originados são 
de tamanho reduzido e imprestáveis para o comércio. Como não se conhece a causa desta anormalidade, atualmente o controle vem sendo feito por meio de erradicação das plantas afetadas (Fundecitrus, 2001). Todas as variedades de laranja doce sobre limão 'Cravo', Poncirus trifoliata e limão 'Volkameriano' são suscetíveis.

No que se refere à utilização de porta-enxerto, atualmente quase toda a agroindústria citrícola paulista está apoiada sobre limão 'Cravo', que apesar de suas excepcionais características, tais como, resistência à seca e a tristeza, média resistência a gomose, e proporcionar boa produção às variedades nele enxertadas, o uso generalizado deste para as mais diversas copas, tipos de solos e climas não atende adequadamente às necessidades de todas as variedades, impedindo que a planta manifeste todo seu potencial produtivo. A principal inconveniência da utilização de um único porta-enxerto já foi demonstrada pela virose da Tristeza que, na década de 40 , destruiu quase toda a citricultura brasileira, então apoiada sobre o porta-enxerto laranja azeda (Pompeu Junior, 1991). No caso de variedades copa, o grande número de sementes e tamanho dos frutos, desfavorece sua importação desestimulando novas áreas de plantio (Amaro et al., 1991)

Por essas razões, a realização de programas de melhoramento visando a obtenção de novas variedades, consiste em um caminho racional a ser seguido na consolidação da citricultura brasileira.

\subsection{Melhoramento de citros no Brasil}

A maioria dos programas de melhoramento de citros basearam-se em métodos convencionais, tais como, seleção clonal, através da ocorrência de mutações somáticas espontâneas em gemas e ramos, hibridação sexual e induções de mutações (Moreira \& Pio, 1991). 
A seleção clonal consiste em eleger "novas variedades" de um cultivar que mantém suas características primárias, mas com maiores produtividades, maturação mais precoce ou tardia, fruto de melhor qualidade ou outras características de interesse (Gosser et al., 1992b). Como exemplos da seleção clonal de mutantes naturais, os mais importantes foram aqueles que deram origem a variedades comerciais como 'Natal', 'Bahia', 'Baianinha', 'Westin', 'Piralima', 'Lima Verde', 'Folha Murcha', dentre outras (Teófilo Sobrinho et al., 1978; Domingues et al., 1995; Donadio et al., 1995).

Os trabalhos de hibridação sexual foram iniciados nos anos 50 , por Donadio e Teófilo Sobrinho, produzindo híbridos de laranja doce, os quais não apresentaram valor comercial (Donadio \& Teófilo Sobrinho, 1975). Em 1974, foram produzidos híbridos entre tangerina 'Satsuma' e diversos parentais masculinos (Donadio \& Stuchi, 1992), resultando em híbridos com alta heterozigose. No entanto, algumas progênies merecem melhor avaliação por apresentarem tolerância ao cancro cítrico (Busquet et al., 1975) e a CVC (Li, 1997).

$\mathrm{Na}$ década de 80 , Donadio lança nova variedade de tangerina, a 'Jaboti', obtida do cruzamento entre tangerina 'Satsuma' x Mexerica-doRio, a qual mostrou-se muito promissora ao mercado por apresentar frutos de tamanho médio, com poucas sementes e serem fáceis de descascar (Moreira \& Pio, 1991).

Em 1990, foi iniciado um programa de hibridação sexual, no Instituto Agronômico de Campinas, resultando na obtenção de híbridos intergenéricos entre tangerina 'Sunki' (C. sunki) x Severinia buxifolia (Bordignon et al., 1990). Recentemente, híbridos entre Citrus limonia Osbeck cv. 'Cravo' x Poncirus trifoliata (L.) Raf. e limão 'Volkameriano' x limão 'Cravo' foram relatados por Medeiros et al. (2000) e Vilarinhos et al. (2000), respectivamente. 
Quanto à indução de mutações, trabalhos foram conduzidos visando redução do número de sementes e resistência ao cancro cítrico (Donadio et al., 1973; Tulmann Neto et al. 1991), porém sem sucesso.

Dentre os vários programas de melhoramento, a seleção de clones nucelares foi que resultou em maiores ganhos econômicos a citricultura comercial (Salibe et al., 1984). A produção destes foi iniciada na Estação Experimental de Limeira, em torno de 1938 (Moreira, 1962), e foram propagados a partir de 1955 (Salibe et al., 1984; Rodriguez, 1956; Moreira, 1962). Até o momento é um material de grande uso comercial no Brasil (Passos et al., 1973; Figueiredo, 1991).

O melhoramento pela adaptação de plantas pouco tolerantes à tristeza, por preimunização com vírus atenuados e a termoterapia para obtenção de gemas livres de vírus, tem sido feito para algumas variedades (Moreira \& Pio, 1991). Como exemplo, pode-se mencionar a obtenção de clones preimunizados de laranja 'Pêra', viabilizando, portanto o uso comercial da mais importante variedade cítrica do país e pela relação econômica que resultou (Muller \& Costa, 1991; Muller et al., 1999). Possivelmente, após os clones nucelares, este foi um grande avanço para citricultura brasileira.

No que concerne à pesquisa para melhoramento de portaenxertos, os programas dão ênfase a problemas relacionados aos aspectos fitossanitários. Vários são os trabalhos desenvolvidos neste sentido, desde a indicação de porta-enxertos mais tolerantes à tristeza, declínio, gomose, condições de solo, quanto à qualidade e produtividade de frutos (Pompeu Júnior, 1991).

Atualmente, com a utilização das técnicas de cultura de tecidos, os programas de melhoramento tomaram novos impulsos. Em 1996, foi estabelecido em Piracicaba, SP, na Escola Superior de Agricultura "Luiz de Queiroz" e o Centro de Energia Nuclear na Agricultura, um programa utilizando a hibridação somática, para de desenvolvimento de novas 
variedades copa e porta-enxerto. Os primeiros híbridos somáticos de material brasileiro conseguido neste programa foram obtidos entre laranja 'Caipira' + limão 'Cravo', (Mendes-da-Gloria et al., 2000) e tangerina 'Cleópatra' + laranja azeda (Benedito, 1999). Estes híbridos encontram-se em casa-de-vegetação para serem avaliados em relação a sua performance horticultural, bem como aos aspectos fitossanitários.

\subsection{Objetivos do melhoramento}

As plantas cítricas são propagadas assexuadamente. No caso da propagação via sementes as plantas resultantes apresentam longo período juvenil, espinhos agressivos, porte esguio, alto vigor e colheita muito difícil além de onerosa. Portanto, a propagação via sementes é recomendada apenas na instalação de viveiros quando da formação dos porta-enxertos. Quanto à propagação por enxertia, que é o método mais utilizado para os citros, apresenta as seguintes vantagens: uniformidade e precocidade de produção, facilidade na colheita, além de aproveitamento de certas variedades de porta-enxerto pela sua adaptação a certos tipos de solo e resistência às moléstias (Sobrinho, 1991). Portanto, as metas para programas de melhoramento devem levar em consideração que a planta cítrica é constituída por dois indivíduos distintos: o enxerto e o porta-enxerto.

- No melhoramento de porta-enxerto busca-se a obtenção de variedades que sejam tolerantes a fatores bióticos (doenças e pragas) e abióticos (adversidades climáticas e edáficas): Entre os fatores bióticos destacam-se, a tolerância à tristeza, ao declínio, a gomose e a nematóides. Os porta-enxertos também devem possuir diferentes níveis de tolerância a fatores abióticos tais como: baixa temperatura, salinidade, seca, alumínio, alcalinidade e enxarcamento (Gosser \& Gmitter Junior 1990b; Grosser et al., 2000). Além disso, uma boa variedade porta- 
enxerto deve apresentar facilidade de propagação, ser compativel com a variedade copa nele enxertada e induzir boa produção e qualidade de frutos, conferir vigor reduzido para facilitar o planejamento e condução dos pomares em populações adensadas. (Pompeu Junior 1991).

- Esses princípios também se aplicam para o desenvolvimento de novos cultivares copa; em que já é sabido que diferentes cultivares apresentam tolerância diferenciada a doenças como clorose variegada dos citros, leprose, tristeza, dentre outras. As metas para o melhoramento de variedades copa incluem características horticulturais relacionadas à produtividade e qualidade de frutos, bem como tolerância a pragas e doenças. Variedades copa devem produzir frutos com ausência ou baixo número de sementes, boa coloração interna e externamente, assim como alto rendimento de suco (acima de $50 \%$ do peso) (Soost \& Cameron, 1975; Grosser \& Gmitter Junior, 1990b).

\subsection{Dificuldades dos programas de melhoramento}

Embora exista uma grande variabilidade genética dentro do gênero Citrus e outros gêneros relacionados, 0 melhoramento convencional tem tido pouco sucesso no desenvolvimento de variedades cítricas (Grosser \& Gmitter Junior, 1990a, Grosser et al., 2000). Os mesmos autores reportam que a maioria das variedades copa e portaenxerto de Citrus utilizadas atualmente originaram-se de mutação e seleção de variedades já existentes e não por programas de melhoramento.

- A ausência de resultados significativos a partir desses programas é atribuída a barreiras naturais ao melhoramento convencional relacionadas à biologia reprodutiva do gênero Citrus, bem como gêneros afins. Entre essas limitações, destacam a poliembrionia nucelar; alta heterozigose, esterilidade de pólen e óvulo; incompatibilidade sexual e 
juvenilidade. (Vardi, 1981; Vardi et al., 1982; Ling et al., 1989; Vardi \& Galun, 1989; Grosser \& Gmitter Junior, 1990b).

A poliembrionia é um fenômeno pelo qual há ocorrência de mais de um embrião dentro da semente (Asker, 1979). Estes embriões podem ser de origem sexuada ou nucelar. Quando cultivares poliembriônicas são utilizadas como parental materno, poucos ou nenhum "seedling" zigótico são produzidos, já que a embrionia nucelar restringe e frequentemente anula o desenvolvimento do embrião zigótico na maturação da semente (Kobayashi \& Ohgawara, 1988). O efeito mais marcante da poliembrionia está na ausência ou na produção de poucas plantas híbridas a partir de cruzamentos controlados (Cameron \& Frost, 1968; Soost \& Cameron, 1975; Grosser \& Gmitter Junior, 1990b).

A alta heterozigose dos citros pode ter sido resultante de polinizações cruzadas realizadas por insetos, já que a ocorrência natural de cruzamentos intervarietais e mesmo interespecíficos é relativamente fácil nos citros (Koller, 1994). Assim, muitos híbridos produzidos naturalmente no campo são perpetuados via embrionia nucelar (Davies \& Albrigo, 1994), fato que dificulta um melhor conhecimento da genética dos citros.

A esterilidade gametofítica (pólen e óvulo), assim como auto e aloincompatibilidade impedem muitas hibridações potenciais (Soost \& Cameron, 1975; Grosser \& Gmitter Junior, 1990b). Hibridação sexual entre Citrus e gêneros da subfamília Aurantioideae tem sido rara, com exceção de alguns gêneros afins, tais como Fortunella e Poncirus trifoliata.

É esperado que a autofecundação e cruzamentos entre indivíduos geneticamente próximos produzam progênies algo similares aos progenitores; entretanto, nas espécies cítricas estas progênies geralmente são fracas ou inferiores, como resultado da depressão por endogamia (Swingle \& Reece, 1967; Barret \& Rhodes, 1976), onde genes 
deletérios antes mascarados por genes dominantes são expressos devido à segregação meiótica (Grosser \& Gmitter Junior, 1990b). Devido a isto, dentre os muitos híbridos obtidos por fecundação controlada pelo homem não apresentam valor comercial e são poucos vigorosos (Moreira \& Pio, 1991). A autofecundação de híbridos F1 com maior heterozigosidade pode ser mais vantajosa no melhoramento, mas não tem sido adequadamente investigada. Por outro lado, indivíduos mostrando características interessantes são comumente usados como progenitores, mas não existe nenhuma garantia que tais características estarão presentes regularmente nos híbridos (Cameron \& Frost, 1968; Gosser \& Gmitter Junior 1990a).

Parentais monoêmbrionicos que produzem somente "seedlings" zigóticos podem ser utilizados no sentido de criar populações segregantes, no entanto, o número de parentais desta natureza é muito pequeno, o que limita drasticamente o grupo de parentais maternos que podem ser utilizados em programas de melhoramento (Grosser \& Gmitter Junior, 1990b). Alguns híbridos entre variedades cítricas, bem como entre gêneros da família da Rutaceae foram produzidos através da hibridação natural, tais como: 'Murcote' (Citrus reticulata Blanco $\times$ Citrus sinensis L. Osbeck), citranges 'Carrizo' e 'Troyer' (Poncirus trifoliata Rafinesque $x$ Citrus sinensis L. Osbeck), tangelos 'Orlando' e 'Nova' (Citrus reticulata Blanco x Citrus paradisi Macfadyen).

A maioria das espécies de citros têm longo período juvenil, levando 5 ou mais anos até o primeiro florescimento e produção (Soost \& Cameron, 1975; Grosser \& Gmitter Junior, 1990b) e de 10 a 15 anos para que possam ser bem analisadas as características de produção e qualidade do fruto. Aliado a este fato, a juvenilidade dos citros está associada à presença de espinhos, árvores com hábito de crescimento vertical e grande vigor, resultando em árvores de grande tamanho. Portanto todos estes fatores tornam o melhoramento de citros muito 
longo, caro, além de exigir uma grande extensão de área (Davies \& Albrigo, 1994; Koller, 1994; Hansche, 1983).

\subsection{Melhoramento utilizando-se técnicas biotecnológicas}

O aumento do potencial de produtividade da maioria das espécies agronômicas vem ocorrendo de forma consistente. Recentemente, a diversidade de procedimentos científicos utilizados no melhoramento de plantas foi expandida com o desenvolvimento da Biotecnologia Vegetal.

A biotecnologia consiste no desenvolvimento de produtos por processos biológicos, utilizando-se a cultura de tecidos, transformação genética, fusão de protoplastos, entre outros, que incorporada em programas de melhoramento, permite facilitar e acelerar a utilização da variabilidade disponível (Grosser et al., 1996b), criando novas combinações genéticas que poderão ser incluídas em programas de melhoramento convencional, ou resultar em variedades totalmente novas (Gmitter Junior et al., 1992; Ollitraut \& Luro, 1995).

A cultura de tecidos em citros iniciou com os trabalhos de Ranga Sway $(1958 ; 1959)$ que, aproveitando a capacidade natural de proliferação das células de tecidos nucelares, os estabeleceu in vitro, com a finalidade de obter plântulas livres de vírus. Posteriormente, foram obtidos embrióides, in vitro, de diversas variedades poliembriônicas (Kochba et al., 1972; Mitra \& Chaturvedi, 1972) e monoembriônicas (Rangan et al., 1968,1969; Bitters et al., 1970; Deidda, 1973; Esan, 1973; Juarez et al., 1976; Navarro \& Juarez, 1977; Button \& Kochba, 1977).

Apesar do grande impacto da cultura de nucelos, está técnica foi substituída pela microenxertia, quando aplicada à limpeza clonal, que além de recuperar plantas livres de vírus mantém as características adultas destas, indispensáveis no ponto de vista comercial (Navarro, 1984). 
Atualmente, técnicas de cultura de tecidos são realizadas não apenas para limpeza clonal, mas como uma ferramenta em programas de melhoramento genético na obtenção de híbridos somáticos por fusão de protoplastos (Grosser \& Gmitter Junior, 1990a) e de plantas transgênicas (Kobayashi \& Uchimuya, 1989; Penã et al., 1995a, 1995b; Penã et al., 1997).

\subsubsection{Cultura de calos embriogênicos}

O primeiro relato do cultivo de calos embriogênicos foi mencionado por Kochba et al. (1972) trabalhando com óvulos imaturos e nucelo da laranja 'Shamouti'. A partir de então, muitos trabalhos descrevem a obtenção de calos embriogênicos utilizando tecidos nucelares (Vardi et al., 1982; Cristofani, 1991; Vu et al., 1993; Oliveira et al., 1994a; Mendes-da-Glória et al., 1999), embriões adventícios de Microcitrus (Vardi et al., 1986), região do hipocótilo de embriões de laranja doce, tangerina 'Poncãn' (Hidaka \& Kajiura, 1988) e Citrus madurensis Lour (Ling et al., 1989), óvulos não fertilizados extraídos de frutos maduros (Kochba et al., 1972; Vardi et al., 1982; Moore, 1985; Gmitter Junior \& Moore, 1986; Benedito et al., 2000) e óvulos imaturos fertilizados (Kobayashi et al., 1983).

A maioria dos trabalhos descritos na literatura menciona metodologias de obtenção de calos embriogênicos utilizando como explantes óvulos inteiros, devido à extração de nucelos ser muito trabalhosa (Kochba et al., 1972; Navarro et al., 1979). Entretanto, a cultura de óvulos apresenta desenvolvimento lento (Navarro \& Juarez, 1977; Pasqual, 1985; Goldman, 1988), menor porcentagem de indução de calos (Kochba et al. 1972; Goldman, 1988) e problemas com o desenvolvimento de calos não embriogênicos a partir de outros tecidos do óvulo (Pasqual et al., 1988; Goldman, 1988). Normalmente, linhagens de 
calo obtidas a partir da região chalazal do óvulo não são embriogênicos (Spiegel-Roy \& Kochba 1980).

O meio de cultura mais utilizado para indução e cultivo de calos é o MT (Murashige \& Tucker, 1969), suplementado com $500 \mathrm{mg} \cdot \mathrm{L}^{-1}$ de extrato de malte e 50 g. $\mathrm{L}^{-1}$ de sacarose (Kochba et al., 1972; Kochba \& Spiegel-Roy, 1973; Vardi et al., 1982). Dentre os componentes do meio de cultivo, a adição de substâncias complexas, como o extrato de malte, a concentração de carboidratos e de reguladores vegetais têm sido relatada como sendo de fundamental importância na indução de calos embriogênicos (Oliveira, 1993). Segundo Kochba \& Spiegel-Roy (1973), calos de Citrus cv. sinensis 'Shamouti' apresentaram uma capacidade embriogênica contínua quando cultivados em meio de cultura com extrato de malte. $O$ efeito benéfico deste componente no meio de cultura foi relatado por diversos pesquisadores (Rangan et al., 1968, 1969; Bitters et al., 1970; Button \& Bornmam, 1971; Kochba et al., 1972; Mitra \& Chaturvedi, 1972; Spiegel-Roy \& Kochba, 1980). No entanto, por ser uma substância complexa se desconhece o componente que possui efeito benéfico na embriogênese (Oliveira, 1993).

Segundo Ben-Hayyin \& Neuman (1983), os principais carboidratos utilizados como fonte de carbono na cultura de tecidos de citros são sacarose, glicerol, galactose e lactose. Kochba et al. (1982) estudaram o efeito de diversos carboidratos (sacarose, galactose, lactose, glicose e frutose) no crescimento de calos nucelares em cinco cultivares de citros. Verificaram què a galactose e a lactose estimularam a embriogênese em todos os cultivares estudados, enquanto que a sacarose sustentou 0 crescimento dos calos. Por outro lado, Button (1978) observou que a sacarose em altas concentrações, $146 \mathrm{mM}$, é eficiente na indução e multiplicação de calos.

Alguns reguladores vegetais são utilizados para a indução da calogênese. Os principais reguladores empregados são as auxinas: ácido 
2,4-diclorofenoxiacético (2,4D) (Vardi et al., 1982) e ácido endolacético (AIA) (Oliveira, et al., 1994a); a citocinina, benzilaminopurina (BAP) (Saito et al., 1991, 1993; Oliveira et al., 1994a; Mendes-da-Glória et al., 1999; Benedito et al. 2000) e cinetina (KIN) (Hidaka, 1995).

Oliveira et al. (1994a) observaram que nucelos de tangerina 'Cleópatra' em meio com AIA e cinetina responderam em $78,8 \%$, enquanto a mesma variedade em meio com BAP resultou em $16,3 \%$ de resposta. Zanol et al. (1997) verificaram que tangerinas 'Cleópatra', 'Sunki' clone CNPMF 02 e Iaranja 'Hamlin' clone 20, apresentaram 34,6\%; 30,7\% e $23,5 \%$ de formação de calos, respectivamente, em meio de cultura MT, suplementado com $500 \mathrm{mg} \cdot \mathrm{L}^{-1}$ de extrato de malte e $10 \mathrm{mg} \cdot \mathrm{L}^{-1}$ de BAP. Entretanto, não se obteve resultado na indução a calogênese com limão 'Cravo' clone Santa Bárbara, limão 'Volkameriano', limão 'Rugoso Mazoe', Iaranja 'Hamlin' clone 04, laranja azeda; Poncirus trifoliata e citranges 'Carrizo', 'Troyer' e 'C-35'.

Em algumas espécies de Citrus, a calogênese independe da presença de reguladores vegetais no meio de cultivo. Benedito et al. (2000) verificaram a superioridade da laranja 'Rubi', que apresentou calogênese em $12,5 \%$ e $15 \%$ dos óvulos introduzidos nos meios de cultura com e sem BAP (5 mg. $\left.\mathrm{L}^{-1}\right)$, respectivamente, enquanto em outras variedades não foi conseguido induzir a calogênese em ambos os meios utilizados.

Este efeito da espécie também foi constatado por outros autores. Mourão Filho \& Grosser (1992), ao trabalharem com 30 seleções de citros, constataram que a resposta foi variável desde espécies não responsivas como Clausena lansium, até outras que produziram calos friáveis de rápida proliferação como o limão 'Rugoso'. Outra constatação neste mesmo trabalho foi a influência de tipos de reguladores vegetais na qualidade dos calos. O limão 'Rugoso' apresentou calos friáveis em meio de cultura com 2,4D $(0.03 \mathrm{mM})$ e cinetina $(0.001 \mathrm{mM})$, enquanto em meio 
onde a auxina utilizada foi 0 ANA (ácido naftalenoacético) na concentração de $0.030 \mathrm{mM}$, os calos apresentaram pouco friável. Oliveira et al. (1994a) conseguiram a calogênese com a tangerina 'Cleópatra' obtendo $48,8 \%$ de resposta, no entanto sem sucesso com o Poncirus trifoliata. Mendes-da-Glória et al. (1999) trabalhando com diversas variedades cítricas, não obtiveram formação de calos nas variedades 'Natal' e 'Pêra', enquanto 'Serra-d'água' e 'Valência' foram menos responsivas em relação às tangerinas 'Poncãn' e 'Cravo' e o híbrido tangor 'Murcote', que apresentou mais de $40 \%$ de resposta.

Os calos obtidos podem ser cultivados por longos períodos na ausência de luz, temperatura de $27^{\circ} \mathrm{C}$ e subcultivados em intervalos de trinta dias, desde que mantidos em meio de cultura adequado (Grosser et al., 1995), com alta concentração de sacarose (146 a 234 mM) (Hidaka \& Omura, 1989), sem a presença de reguladores vegetais, pois em alguns casos podem elevar a taxa de variação somaclonal. Oliveira et al. (1994a) analisando o crescimento de calos, pela determinação de peso da matéria fresca, para as cultivares tangerina 'Cleópatra' e limão 'Cravo' concluíram que quando cultivados em meio de cultura apropriado, os calos duplicam a quantidade de matéria fresca num período de quatro semanas, ocorrendo a habituação dos mesmos, ou seja, o crescimento ocorre sem a adição de reguladores vegetais ao meio de cultura. No caso em que os calos embriogênicos apresentem crescimento lento e oxidação, a transferência para meios de cultura contendo carvão ativado $0.5 \mathrm{~g} . \mathrm{L}^{-1}$ proporcionará melhores condições de crescimento (Mourão Filho \& Grosser, 1992; Mendes-da-Gloria, 1998).

\subsubsection{Cultura de suspensões celulares}

A partir de calos embriogênicos e friáveis, pode-se iniciar 0 cultivo de suspensões celulares, uma vez que a composição do calo 
possibilita que as células desagreguem-se em meio de cultura líquido sob agitação (Oliveira et al., 1994b; Jiménez, 1996; Cabasson et al., 1997). Este sistema de cultivo constitui-se em uma alternativa para aumentar a quantidade de células embriogênicas num curto espaço de tempo (Carneiro et al., 1998). No entanto, constante monitoramento deve ser feito, pois devido à alta taxa de multiplicação celular, uma das suas principais vantagens em relação ao meio sólido, pode-se observar um alto indice de variação somaclonal (Cid, 1998), o que se torna preocupante dependendo do objetivo do trabalho.

Em geral os meios de cultura mais amplamente utilizados no cultivo de células em suspensão são o MT (Murashige \& Tucker, 1969) modificado com 50 g. $\mathrm{L}^{-1}$ de extrato de malte, e $\mathrm{OH}+\mathrm{H}$, onde se reduz as fontes de ions amônio e nitrato e se acrescenta glutamina (Grosser \& Gmitter Junior, 1990b).

As células da cultura em suspensão são normalmente uniformes, possuem parede celular fina, um citoplasma denso e um ritmo acelerado de divisão, com uma curva de crescimento exponencial. A manutenção deste ritmo de crescimento é feita por subcultivos periódicos, normalmente em intervalos de 15 dias (Mendes, 1999).

O conhecimento das fases de crescimento de uma suspensão celular dentro de cada subcultivo é bastante importante, uma vez que a capacidade embriogênica das células em suspensão pode ser mantida pela realização de subcultivos nas fases de crescimento logarítmico das células (Ammirato, 1984) ou de desaceleração progressiva (Dodds \& Roberts, 1985). Oliveira et al. (1994b) trabalhando com suspensões celulares, verificaram que a fase de crescimento logarítmico das células ocorreu aproximadamente do $6^{\circ}$ ao $12^{\circ}$ dia para a tangerina 'Cleópatra', e do $8^{\circ}$ ao $16^{\circ}$ para o limão 'Cravo'. Baseado nestes resultados, os autores recomendam os subcultivos a cada 12 dias para suspensões celulares da tangerina e 16 dias para o limão. 
Independente de o material vegetal estar sendo mantido pelo subcultivo de calos ou células em suspensão, estes explantes são tidos como as melhores fontes com capacidade embriogênica para o isolamento de protoplastos de citros (Grosser \& Gmitter Junior, 1990a).

\subsubsection{Protoplastos: isolamento, cultivo e regeneração de plantas}

O termo protoplasto é normalmente utilizado para descrever células livres de parede celular. A ausência da parede faz dos protoplastos um sistema útil para diversos estudos, tais como, extração de organelas celulares; transferência gênica através da técnica de transformação genética e produção de novos genótipos por hibridação somática (Fungaro \& Vieira, 1989; Grosser \& Gmitter Junior, 1990a; 1990b).

Tentativas de se isolar protoplastos vegetais viáveis datam do final do século XX. A técnica utilizada baseava-se na retirada mecânica da parede celular de células parcialmente plasmolizadas (Evans \& Cocking, 1977). Isto restringe a aplicação da metodologia às células parenquimatosas de tecidos de reserva e mesmo assim, com uma produção muito baixa de protoplastos viáveis (Dornelas, 1995).

Com o aperfeiçoamento da técnica de digestão enzimática da parede celular tornou-se possível 0 isolamento de protoplastos viáveis, virtualmente de qualquer tecido vegetal (Cocking, 1960).

De modo geral, as preparações enzimáticas mais comumente utilizadas incluem a adição de celulase, produzida pelo fungo Trichoderma viride, driselase e macerase, provenientes de Basidiomiceto e Rhizopus, respectivamente (Fungaro \& Vieira, 1989).

Nas soluções enzimáticas também são adicionados estabilizadores osmóticos do meio de cultura e de membrana para manter os protoplastos íntegros e tampões para evitar alterações de $\mathrm{pH}$. 
Os principais estabilizadores osmóticos utilizados são manitol, sorbitol, sacarose, glucose, galactose e celobiose (Evans \& Bravo, 1983; Vasil \& Vasil, 1980; Erikson, 1985). O uso de estabilizadores osmóticos metabolicamente ativos como a glucose, sorbitol e sacarose em combinação com estabilizadores inertes, como manitol, são recomendados por promover redução gradual na pressão osmótica do meio de cultura, proporcionando condições favoráveis à formação de colônias de células (Vasil \& Vasil, 1980; Erikson, 1985; Carneiro et al., 1998). A maioria dos trabalhos de isolamento de protoplastos de citros utiliza a concentração de $0,7 \mathrm{M}$ proposta por Vardi et al. (1982). Com relação aos estabilizadores de membrana, a adição de cálcio e fósforo na solução enzimática, confere estabilidade aos protoplastos recém isolados (Carneiro et al., 1998).

O primeiro isolamento de protoplastos de citros, com posterior recuperação de embrióides foi relatado por Vardi et al. (1975) em Citrus sinensis cv. 'Shamouti'. Posteriormente, foram estabelecidos protocolos para diversas variedades e espécies de citros. Assim foi aberto o caminho para os estudos genéticos celulares e para novas abordagens no melhoramento genético de espécies cítricas.

Os protoplastos de citros podem ser isolados a partir de calos embriogênicos e de células em suspensão (Grosser \& Gmitter Junior, 1990b). No entanto, segundo Carneiro et al. (1998), em geral, o isolamento a partir de suspensões celulares são os mais utilizados pela facilidade de manipulação e eficiência de isolamento. Protoplastos também têm sido isolados de folhas, que apesar de não serem embriogênicos, são úteis em experimentos de fusão com protoplastos de calo ou células em suspensão, permitindo o monitoramento visual da ocorrência de heterocariontes e a utilização de genótipos dos quais não foi possivel a obtenção de calos embriogênicos (Grosser \& Chandler, 1987). 
Os principais fatores determinantes na eficiência de isolamento de protoplastos estão relacionados ao genótipo, estado fisiológico das células, tipo e concentração de enzimas e estabilizadores osmóticos, tempo de incubação na solução enzimática, agitação, luminosidade e temperatura (Evans \& Bravo, 1983; Gleide, 1985; Carneiro et al., 1998).

Os requisitos nutricionais para o cultivo de protoplastos são muito similares aos exigidos para a cultura de suspensões celulares, no entanto, os meios de cultura de protoplastos tendem a conter níveis reduzidos de substâncias inorgânicas e elevados de substâncias orgânicas, pois devido à ausência de parede, os protoplastos tendem a ser mais eficientes na absorção de nutrientes (Fungaro \& Vieira, 1989). Baseado nesse princípio, Vardi et al. (1982) recomendam o meio de cultura MT e Grosser \& Gmitter Junior (1990b) o meio $\mathrm{BH}_{3}$ para o cultivo de protoplastos de citros, o qual ao contrário do meio MT, apresenta uma composição bastante complexa, contendo um grande número de vitaminas e açúcares que proporciona uma alta viabilidade e eficiência de plaqueamento (Kao \& Michayluk 1974).

Vários são os métodos pelos quais os protoplastos podem ser cultivados, entretanto os dois principais grupos podem ser: sistemas de cultura em meio líquido e cultura de protoplastos imobilizados em meio semi-sólido. Entre os métodos de cultura em meio líquido, encontra-se: cultura em suspensão, cultura em gota pendente e em câmaras de microcultura. Entre os sistemas de protoplastos imobilizados estão: a cultura em gotas ou fatias de agarose (Fungaro \& Vieira, 1989; Evans, 1991).

A solidificação do meio de cultura com ágar, agarose, alginato ou poliacrilamida tem sido empregada por vários autores, sendo que os melhores resultados foram encontrados com agarose (Carlberg et al., 1983; Lorz et al., 1983; Shillito et al., 1983). O cultivo de protoplastos imobilizados é muito mais eficiente que o cultivo em meio líquido, pois 
evitam a aglutinação dos protoplastos e, portanto, são menos propensos a sofrerem alterações na densidade dos mesmos em cultura (Lorz et al., 1983; Shillito et al., 1983; Colijn-Hooymans et al., 1988). Dornelas (1995) relatou que o sistema de cultura de protoplastos de Passiflora spp em gotas de agarose produziu uma porcentagem de células em divisão e uma eficiência de plaqueamento superiores às observadas ao cultivo em meio líquido.

Binding et al. (1988), trabalhando com Arabidopsis tháliana, e Solanum tuberosum, consideraram que o sistema de cultivo em gotas é mais eficiente que o de camada de agarose, pois as gotas permitem um maior intercâmbio de nutrientes entre a fase sólida e a fase líquida do meio. D'ultra Vaz et al. (1993) relataram que esta maior eficiência do cultivo em gotas estaria relacionada a um maior suprimento de oxigênio, ocasionando uma produção mais efetiva de ATP, com efeitos favoráveis nas divisões celulares; ao contrário, no cultivo em camada de agarose, os protoplastos ficam completamente submersos sob uma lâmina de meio líquido.

A regeneração da parede celular é iniciada 24 horas após 0 plaqueamento, com deposição de microfibrilas (Vardi \& Galun, 1988). Os protoplastos de citros têm uma fase "lag" relativamente extensa, em que as divisões celulares somente se iniciam 10 a 14 dias após 0 plaqueamento (Grosser \& Gmitter Junior, 1990b). Aos 30 dias de cultivo verifica-se a formação de microcolônias (Vardi et al., 1975) e após 8-10 semanas microcalos (Vardi et al., 1982), os quais são então seguidos. pelo desenvolvimento de calos e, finalmente, pela produção de embriões (Vardi et al., 1982; Kobayashi \& Ohgawara, 1988), que resultará no desenvolvimento de plântulas.

A densidade de plaqueamento bem como a molaridade do meio de cultivo, constituem os principais fatores determinantes da eficiência final de plaqueamento, que é definida como a porcentagem de protoplastos 
plaqueados que dividiram e formaram microcalos com 1-2 $\mathrm{mm}$ de diâmetro, visíveis a olho nu, com potencial à conversão em plântulas (Ochatt \& Power, 1992).

-A embriogênese somática constitui-se numa via de regeneração de plantas no cultivo in vitro, em que células somáticas desenvolvem-se formando estruturas semelhantes ao embrião zigótico, sem a ocorrência de fusão de gametas-(Guerra et al., 1998). Entre as diferenças dos embriões somáticos e zigóticos citam-se o desenvolvimento livre de correlações físicas, fisiológicas e genéticas do embrião somático, as quais ocorrem durante 0 desenvolvimento de um embrião zigótico (Zimmermann, 1993). Os embriões somáticos apresentam um sistema vascular fechado, sem conexão com os tecidos adjacentes inicial (Guerra et al., 1998): Apesar dos embriões somáticos serem originados de células somáticas, sua semelhança com os embriões zigóticos leva a presumir que resultem da expressão gênica que regula a mesma via de desenvolvimento.(Parrot et al., 1992).

Os embriões somáticos podem ser formados a partir de dois padrões de embriogênese, a direta ou a indireta. $A$ embriogênese somática direta envolve o desenvolvimento de embriões somáticos no explante, o qual possui células programadas para a diferenciação e formação dos embriões somáticos. Para a embriogênese somática indireta, é necessário a desdiferenciação celular. Nas espécies vegetais, com exceção de citros, a desdiferenciação, indução e formação dos embriões somáticos ocorre pelo cultivo em meios de cultura suplementados com auxinas (Sharp, 1980; Williams \& Maheswaram, 1986). Em ambos os padrões, o embrião somático segue a mesma seqüência de desenvolvimento do embrião zigótico, ou seja, a passagem pelos estádios globular, cordiforme e torpedo, seguido pela formação da planta (Guerra et al., 1998).

$O$ efeito de diversas substâncias na embriogênese de calos cítricos tem sido amplamente estudado. A embriogênese somática em citros é 
inibida por ácido giberélico (Kochba et al., 1978), citocinina e auxina (Kochba \& Spiegel-Roy, 1977; Kobayashi et al., 1984). Como promotores da embriogênese, destacam-se extrato de malte, adenina (Kochba \& Spiegel-Roy, 1973), etileno e ácido abscísico (ABA) (Kochba \& SpiegelRoy, 1977). Entretanto, o fator mais importante na embriogênese é a resposta a alguns carboidratos no meio de cultivo. Button (1978), Kochba et al. (1982), Bem-Hayyim \& Neuman (1983) relataram que a embriogênese somática de calos nucelares pode ser estimulada quando a sacarose do meio de cultura for substituída por galactose, lactose e o glicerol. Kochba et al. (1978) propuseram que este fenômeno pode ser devido a redução da auxina endógena nos calos embriogênicos. Mendesda-Glória (1998) trabalhando com calos de citros oriundos de fusão de protoplatos, concluiu que a maltose foi o carboidrato mais efetivo e a sacarose o que menos estimulou a embriogênese somática. Benedito et al. (2000), estudando a embriogênese somática em variedades de laranjas doces, verificou que a galactose foi o carboidrato que induziu os melhores resultados. Tomaz (2000) relata que a densidade de plaqueamento, em conjunto com a fonte de carbono, pode contribuir para aumentar a eficiência no estímulo à embriogênese somática.

Apesar do grande número de embriões formados a partir de calos embriogênicos, poucas são as plantas que se desenvolvem. Os requisitos básicos para aumentar a eficiência de regeneração são a obtenção de embriões somáticos morfologicamente normais, equilíbrio entre 0 desenvolvimento do sistema radicular e brotos, bem como a composição do meio de cultura, com relação à presença de reguladores vegetais (Gmitter Junior \& Moore, 1986; Gindy, 1990; Avenito, 1991; Song et al., 1991).

A primeira descrição de um sistema para regeneração de plantas por embriogênese somática via protoplasto, foi relatada por Vardi et al. (1975), para variedade 'Shamouti'. Atualmente, tem-se estabelecido 
protocolo para a maioria das espécies de citros e gêneros relacionados (Grosser et al., 1988a; 1988b; Miranda et al., 1997), utilizando calos embriogênicos e cultura de células em suspensão como fonte de proroplasto (Vardi et al., 1975; Grosser \& Gmitter Junior, 1990a).

\subsubsection{Hibridação somática como recurso no melhoramento de citros}

\subsubsection{Importância}

- A hibridação somática é uma técnica que consiste no isolamento e fusão de protoplastos, obtendo híbridos tetraplóides heterozigotos (Gmitter Junior et al., 1992; Carneiro et al., 1998) que contêm toda a informação genética de ambos os parentais. Esta técnica tem vantagens sobre a hibridação sexual, pois consiste em um processo aditivo, não existindo segregação meiótica. Assim, genes deletérios recessivos não expresso nos parentais, provavelmente não irão se expressar nos híbridos somáticos e características controladas por genes dominantes ou co-dominantes em um parental, ou genes recessivos em ambos tem grande probabilidade de se expressar no híbrido somático (Grosser \& Gmitter Junior, 1990a). “A hibridação somática também oferece a oportunidade de se combinar citoplasmas diferentes na mesma célula, as quais não podem ser produzidas por hibridação sexual, pois, o citoplasma materno é preferencialmente herdado.(Fungaro \& Vieira, 1989).

Em programas de melhoramento genético de citros, a hibridação somática tem sido extensivamente aplicada (Grosser \& Gmitter Junior, 1990a; 1990b, Grosser et al., 1990), favorecendo o desenvolvimento de híbridos interespecíficos (Tusa et al., 1990); intergenéricos de parentais sexualmente compatíveis (Grosser et al., 1988a; Deng et al., 1992), intergenéricos de parentais sexualmente incompativeis (Grosser et al., 
1988b, Ling \& Iwamasa, 1994) e cíbridos (Saito et al., 1993, Grosser et al., 1996a).

A utilização da hibridação somática em programas de melhoramento de variedades porta-enxerto envolve duas estratégias. A primeira visa produção de híbridos alotetraplóides, com características complementares de variedades existentes. Uma segunda estratégia é superar barreiras da hibridação sexual produzindo híbridos somáticos intergenéricos entre Citrus e espécies/gêneros relacionados, sexualmente incompatíveis (Grosser \& Gmitter Junior, 1990b). Quanto ao melhoramento de variedades copa, os produtos da hibridação somática não possuem potencial para serem utilizados diretamente, vez que, frutos tetraplóides possuem características não aceitáveis pelo mercado consumidor, como casca grossa e forma irregular (Grosser et al., 1992b), mas podem ser incorporados ao melhoramento como parental tetraplóide ( $2 n=4 x=36$ cromossomos), em cruzamento com variedades diplóide $(2 n=2 x=18$ cromossomos) monoembriônicas, gerando progenie triplóide $(2 n=3 x=27$ cromossomos) (Ohgawara et al., 1991; Grosser et al., 1992a; Mourão Filho et al., 1996; Grosser $t$ al., 2000), potencialmente sem sementes, devido à ausência de complementos cromossômicos não balanceados durante a segregação meiótica. Como exemplo, cita-se 0 cruzamento de tangelo 'Nova' com o híbrido somático tangelo 'Nova' + laranja doce 'Succari' (Grosser et al. 1998c). A hibridação somática também permite combinar variedades as quais 0 melhoramento convencional é inibido por esterilidade de pólen e baixa produção de sementes, como laranja 'Washington Navel' e tangerina 'Satsuma' (Kobayashi et al., 1988b). 


\subsubsection{Técnicas de fusão de protoplatos e obtenção de híbridos somáticos}

Protoplastos recém-isolados de diferentes espécies podem ser induzidos a fundirem-se para dar origem a células híbridas. O primeiro relato de fusão de protoplastos vegetais foi descrito por Power et al. (1970) utilizando-se nitrato de sódio como substância indutora de fusão. Apesar desta técnica ter sido aprimorada por manipulação do $\mathrm{pH}$ da solução salina e da adição de íons de cálcio para melhorar a estabilidade da membrana plasmática, a proporção de protoplastos fundidos era sempre baixa (Evans \& Cocking, 1977). Apenas depois de Kao \& Michayluk (1974) descreverem o uso do polietilenoglicol (PEG) como agente aglutinador e indutor, foi obtida uma porcentagem de protoplastos envolvidos em processos de fusão maior que $25 \%$.

Outro método utilizado para fusão de protoplastos é a técnica da eletrofusão. Esta consiste em submeter os protoplastos a um campo de corrente alternada, de baixa voltagem e a subseqüente aplicação de um ou mais pulso de corrente contínua de alta intensidade. Este tratamento gera poros temporários nas membranas, permitindo a fusão de protoplastos que estiverem próximos (Zimmerman, 1982; Gledde et al., 1985; Carneiro et al., 1998). Segundo os mesmos autores, a técnica da eletrofusão permite obter uma porcentagem de protoplastos envolvidos em fusão maior que a induzida por PEG e melhor reprodutividade dos resultados. Entretanto, requer a disponibilidade de um aparato de custo alto, fato que limita em parte sua ampla utilização.

O método mais utilizado para induzir fusões de protoplastos consiste no tratamento com PEG, em condições salinas (Kao \& Michayluk, 1974). Esta substância aglutinadora é um policátion que possui alta afinidade com a água, propiciando a desidratação dos fosfolipídios constituintes da membrana plasmática, o que favorece uma 
desorganização na arquitetura ao nível de membrana, resultando na fusão química de protoplastos (Evans \& Wilson, 1984). Esse método apresenta elevada eficiência de fusão, baixo custo, não interfere na viabilidade dos protoplastos (Grosser \& Gmitter Junior, 1990b), não requer equipamentos sofisticados (Constabel \& Cutler, 1985), permite o tratamento de um grande número de protoplastos $e$ induz fusões não específicas (Bengochea \& Dodds, 1986).

O sistema de produção de híbridos somáticos por fusão de protoplastos em citros é baseado na capacidade de regeneração de plantas via embriogênese somática a partir de calos (Motomura et al., 1995), sendo a capacidade embriogência de um dos parentais um prérequisito para o sucesso na obtenção de híbridos somáticos.

O primeiro exemplo de hibridação somática em citros foi descrito por Ohgawara et al. (1985). O híbrido intergenérico foi obtido pela fusão de protoplastos induzida por PEG, isolados de calos embriogênicos de Citrus sinensis cv. 'Trovita' com protoplastos isolados de folhas de Poncirus trifoliata. Posteriormente, o mesmo grupo de pesquisadores apresentou dois híbridos somáticos, Citrus sinensis cv. 'Washington Navel' + tangor 'Murcote' (Kobayashi et al., 1988a) e Citrus sinensis cv. 'Washington Navel' + tangerina 'Satsuma' (Kobayashi et al., 1988b), com o objetivo de superar barreiras impostas pela hibridação sexual. Grosser et al. (1989) relataram novo híbrido intergenérico a partir da cultura de protoplastos isolados de lima 'Key' (Citrus aurantifolia) e laranja 'Valência' (Citrus sinensis), o qual deve combinar as características de tolerância ao frio e à tristeza da laranja 'Valência' com o curto período de juvenilidade da lima 'Key'. A partir desta data, outros grupos de pesquisadores iniciaram o uso da hibridação somática em programas de melhoramento, inclusive com a utilização da técnica de eletrofusão (Hidaka et al., 1992; Ling \& Iwamasa, 1994), dando origem a um grande 
número de híbridos somáticos, de diversas espécies e gêneros relacionados aos citros.

Híbridos somáticos interespecíficos de citros direcionados ao melhoramento de copa geralmente têm sido obtidos com ênfase em fusões entre grupos de laranjas doces + tangerinas e seus híbridos (Citrus reticulata $\mathrm{x}$ Citrus paradisi, Citrus reticulata $\mathrm{x}$ Citrus sinensis), (Mourão Filho et al., 1996; Grosser et al., 1992a) buscando melhoria nas qualidades dos frutos. Estes híbridos tetraplóides deverão ser utilizados em cruzamentos com diplóides para gerar progênie zigótica triplóide, potencialmente sem sementes. A exemplo podem ser mencionadas as seguintes combinações: laranja 'Washington Navel' + tangor 'Murcote' (Kobayashi et al., 1991); Iaranja 'Hamlin' + tangerina 'Dancy' (Grosser et al., 1992a); tangerina 'Satsuma' + laranja 'Washington Navel' (Kobayashi et al., 1995); Iaranja 'Succari' + tangerina 'Dancy'; Iaranja 'Succari' + tangelo 'Minneola'; Iaranja 'Succari' + tangor 'Murcote'; Iaranja 'Succari' + tangelo 'Page'; laranja 'Succari' + tangerina 'Poncãn' (Mourão Filho et. al., 1996); laranja doce 'Valência' + tangelo 'Minneola', laranja doce 'Valência' + tangor 'Murcote', laranja 'Valência' + híbrido 3 USDA-CJH (tangerina 'Robinson x tangor 'Temple'), laranja 'Valência Rohde Red' + híbrido 3 USDA-CJH 1 (tangerina 'Fortune' $x$ tangerina 'Kinnow'), laranja 'Valência Rohde Red' + tangerina 'Dancy', tangor 'Murcote' + híbrido LB89 (tangerina 'Clementina $x$ tangelo 'Minneola'), laranja 'Hamlin' + tangerina 'Poncãn' (Grosser et al., 1998c). No melhoramento de portaenxerto destacam-se as fusões: laranja azeda + limão 'Volkameriano', tangerina 'Cleópatra' + laranja azeda, tangerina 'Cleópatra' + limão 'Rugoso', tangerina 'Cleópatra' + limão 'Cravo', laranja. 'Hamlin' + limão 'Cravo', (Louzada et al., 1992); laranja azeda + limão 'Cravo', híbrido (C. jambhiri x C. sinensis) + tangerina 'Sun Chu Sha' (Grosser et al. 1994), tangerina 'Poncãn' + limão 'Rugoso' (Moriguchi et al., 1996); híbrido limão 'Milam' + citrumelo 'Swingle', híbrido limão 'Milam' + citrange 
'Carrizo', laranja azeda + citrange 'Carrizo', laranja 'Succari' + laranja azeda, laranja 'Succari' + 'Kinkoji', laranja 'Succari' + limão 'Rugoso', tangerina 'Cleópatra' + limão 'Rugoso', tangelo 'Nova' + lima da Pérsia (Grosser et al., 1998b); limão 'Cravo' + tangerina 'Cleópatra' (Latado, 1998), laranja 'Caipira' + tangerina 'Cleópatra', Iaranja 'Caipira' + limão 'Volkameriano', laranja 'Caipira' + tangerina 'Sunki' (Mendes, 1999), com ênfase em combinar características complementares de resistência a doenças.

Quanto à utilização de gêneros relacionados aos citros na hibridação somática, pode ser destacado: a) híbridos intergenéricos de Citrus com pais sexualmente compativeis como: laranja 'Trovita' + Poncirus trifoliata (Ohgawara et al., 1985); Iaranja 'Hamlin' + Poncirus trifoliata cv. 'Flying Dragon' (Grosser et al., 1988a); tangerina 'Cleópatra' + citrumelo 'Swingle', tangerina 'Cleópatra' + Poncirus trifoliata cv. 'Flying Dragon' (Grosser et al., 1992a); laranja 'Valência' + citrange 'Carrizo' (Louzada et al., 1992); Iaranja 'Succari' + Poncirus trifoliata cv. 'Argentine', tangerina 'Cleópatra' + Poncirus trifoliata cv. 'Argentine', laranja azeda + Poncirus trifoliata cv. 'Flying Dragon' (Grosser et al., 1994); pomelo 'Red Marsh' + Poncirus trifoliata cv. 'Argentine', pomelo 'Red Marsh' + Poncirus trifoliata cv. 'Flying Dragon', laranja 'Succari' + kunquat 'Meiwa', kunquat 'Meiwa' + tangerina 'Dancy', kunquat 'Meiwa' + tangerina 'Chansha', Iaranja 'Succari' + Microcitrus papuana, Iaranja 'Hamlin' + Microcitrus papuana (Grosser et al., 1996b), aproveitando as boas características agronômicas destes gêneros relacionados à resistência ao frio, tolerância à salinidade e resistência a doenças; b) híbridos intergenéricos com pais sexualmente incompativeis: laranja 'Hamlin' + Severinia disticha (Grosser et al., 1988b); Iaranja 'Hamlin' + Citropsis gilletiana (Grosser \& Gmitter Junior, 1990a); Iaranja 'Hamlin' + Severinia buxifolia (Grosser et al., 1992a); tangerina 'Poncãn' + Citropsis gabunensis (Ling \& Iwamasa, 1994); tangelo 'Seminole' + Severinia 
buxifolia, tangelo 'Seminole' + Atalantia monophylla (Motomura et al., 1995); Iaranja 'Succari' + Severinia buxifolia, Iaranja 'Hamlin' + Severinia disticha, laranja 'Valência' + Severinia disticha, tangerina 'Cleópatra' + Severinia disticha, tangelo 'Nova' + Severinia disticha, laranja 'Succari' + Atalantia ceylanica, laranja 'Succari' + Feronia limonia, tangelo 'Nova' + C. ichangesis (Grosser et al., 1996b); Kunquat 'Maiwe' + Poncirus trifoliata (Miranda et al., 1997); tangelo 'Page' + Murraya paniculata (Guo \& Deng, 1998). Produção destes híbridos demonstraram que a fusão de protoplastos é viável principalmente para quebrar barreiras relacionadas à incompatibilidade sexual que existem entre Citrus e gêneros relacionados com características potencialmente importantes.

Além dos híbridos somáticos completos, também foi descrito na literatura transferência de organelas. Vardi et al. (1989) relataram a transferência da macho-esterilidade citoplasmática que ocorre em plantas do gênero Microcitrus, para genótipos de laranja azeda e limão 'Rugoso'. Segundo estes autores, cultivares de Citrus portadores de machoesterilidade podem ter alto valor econômico, se esta característica também estiver associada à partenocarpia, para produção de frutos sem sementes. Saito et al. (1993) relataram a obtenção de cíbridos de lima (C. aurantifolia) e limão (C. limon), e verificaram a recombinação do DNA mitocondrial (DNAmt) das espécies envolvidas na fusão, além da eliminação preferencial dos cloroplastos de lima ou limão. Moriguchi et al (1997), relatam que o material genético mitocondrial está relacionado ao parental embriogênico, indicando o papel do DNAmt no processo embriogênico.

Análises do comportamento de híbridos somáticos em condições de campo têm evidenciado que as plantas apresentam bom desenvolvimento com fertilidade de óvulo e pólen (Kobayashi et al., 1991). Observações preliminares dos híbridos somáticos de portaenxertos, contendo o Poncirus trifoliata como parental, indicam 0 
desenvolvimento de árvores com tamanho reduzido (Grosser et al., 1998a), característica esta que permite plantios mais adensados (Grosser et al., 1995). Quanto à resistência a doenças, verificou-se que os hibridos de laranja azeda + limão 'Cravo' e laranja azeda + citrange 'Carrizo' têm demonstrado resistência ao vírus da tristeza (Grosser et al., 1998a).

\subsubsection{Efeito da ploidia nas células da epiderme foliar dos híbridos somáticos}

Uma característica comum de indivíduos poliplóides (naturais ou artificiais) é o aumento de suas partes vegetais (efeito giga), tornando os poliplóides geralmente bem mais vigorosos do que os diplóides correspondentes (Allard, 1971). O aumento da ploidia de uma planta causa um incremento no tamanho de seus tecidos, devido ao maior volume celular. Desta forma, o número de estômatos bem como seu tamanho estão correlacionados com o nivel de ploidia da planta (Suzuki et al., 1981). Borges (1971) encontrou uma relação proporcional entre o nível de ploidia e o tamanho dos estômatos e concluiu que a análise dos estômatos em poliplóides possui valor diagnóstico na identificação destes materiais.

\subsubsection{Confirmação da híbridação somática}

A verificação e confirmação dos híbridos somáticos obtidos pode ser feita pela análise morfológica foliar, por determinações citológicas e por caracterização molecular, mediante marcadores como isoenzimas e RAPD (DNA polimórfico amplificado ao acaso) (Grosser \& Gmitter Junior, 1990b). Entretanto, nenhum destes métodos aplicados individualmente é suficiente para caracterização dos híbridos somáticos.

As características morfológicas tais como folha trilobadas (Ohgawara et al., 1985; Grosser et al., 1988b) e presença de pecíolos 
alados (Vardi et al., 1987, Ballve et al., 1997) são usados em vários trabalhos como marcadores morfológicos para identificar prováveis híbridos. Entretanto, em combinações interespecíficas, a morfologia vegetativa, intermediária dos híbridos em relação aos parentais não se apresenta evidente (Grosser et al., 1988a).

Quanto às análises citológicas referem-se a contagem do número de cromossomos durante a mitose. Esta análise apenas revela a natureza poliplóide das plântulas regenerantes pois, pode ocorrer a regeneração de plantas autopoliplóides que, apesar de sua natureza tetraplóide não se caracteriza como híbrido somático (Grosser et al., 1988a).

0 método isoenzimático é baseado nas múltiplas formas moleculares da mesma enzima que ocorre em uma espécie, como resultado da presença de mais de um gene codificando cada uma das enzimas (Grosser \& Gmitter Junior, 1990b). Entretanto, algumas limitações impedem sua ampla utilização, tais como: polimorfismo isoenzimático em resposta a condições ambientais; modificações póstradução das enzimas, produzindo formas múltiplas do produto de um único gene, as quais diferem em estrutura secundária e terciária; diferenças na atividade isoenzimática associada a estádios diferentes de desenvolvimento; dentre outras.

Vários sistemas isoenzimáticos têm sido empregados nos trabalhos de Citrus e variam em função dos parentais usados no experimento. Os mais utilizados são a fosfohexose isomerase (PHI) e a fosfoglucose mutase (PGM), usados para discriminar híbridos entre Citropsis gilletiana e tangerina 'Cleópatra' (Grosser \& Gmitter Junior,1990a). Outros sistemas bastante usados são o da peroxidase (PPX) (Deng et al., 1992), fosfoglucose isomerase (PGI) (Louzada et al., 1992) glutamato oxaloácetico transaminase (GOT) (Ling \& Iwamasa, 1994) e a malato desidrogenase (MDH), usada para discriminar híbridos entre Poncirus trifoliata + Iaranja 'Hamlin' (Grosser et al., 1988a). 
Os híbridos somáticos analisados pelo sistema isoenzimático, apresentaram complementação alélica, ou seja, o padrão complementar das duas espécies parentais. Algumas exceções foram relatadas por Louzada et al., (1992). Plantas híbridas entre laranja azeda + limão 'Volkameriano' não apresentaram, para PGM, o alelo $S$, presente no padrão das duas espécies parentais. Outro exemplo aconteceu na fusão entre Citrus jambhiri + Citrus limonia, em que se observou a ausência do alelo $M$, mas em análises posteriores verificou-se que este alelo estava ausente nos calos de Citrus jambhiri.

Atualmente, marcadores moleculares baseados em RAPD têm sido os mais utilizados. Apresentam substanciais vantagens em relação ao método isoenzimático, pois, se baseiam na utilização de "primers" de seqüência arbitrária para dirigir a reação de amplificação do DNA, resultando em maior simplicidade e rapidez das análises (Ferreira \& Grattapaglia, 1995).

Uma característica fundamental dos marcadores RAPD é o fato de se comportarem como marcadores genéticos dominantes. Ao se observar um fragmento no gel, não é possível distinguir indivíduos diplóides homozigotos $(A A)$ ou heterozigotos $(A b)$ para o mesmo loco RAPD, pois ambos possuem o "alelo" A que será amplificado. A detecção dos segmentos RAPD não tem sensibilidade quantitativa suficiente para discriminar os dois casos. O genótipo recessivo (aa) seria identificado pela ausência de fragmentos no gel (Ferreira \& Grattapaglia, 1995).

Grosser et al. (1996b) utilizaram marcadores RAPD para discriminar 18 novos híbridos somáticos entre espécies de Citrus. As plantas híbridas analisadas apresentaram padrões de bandas complementares às duas espécies parentais fusionadas.

Mourão Filho et al. (1996) também utilizaram a análise de marcadores RAPD para confirmar a natureza híbrida de plantas obtidas 
em experimentos de fusão entre laranja 'Succari' + tangelo 'Minneola', utilizando os "primers" OPPA-10, OPU-17, OPW-5 e OPX-18.

A partir de 1996, a técnica de marcadores RAPD vem sendo utilizada com o sucesso na confirmação de híbridos somáticos em Citrus.

Outros métodos de confirmação da hibridação são apontados, como o estudo das subunidades polipeptídicas da RUBISCO, o padrão de restrição mitocondrial (DNAmt) e do DNA do cloroplasto (DNAcp) (Morikawa \& Yamada, 1992). Entretanto, estes métodos mais sofisticados ainda não estão muito difundidos nos trabalhos de hibridação de citros. 


\section{MATERIAL E MÉTODOS}

Os trabalhos experimentais foram conduzidos no Laboratório de Biotecnologia de Plantas Hortícolas do Departamento de Produção Vegetal da Escola Superior de Agricultura "Luiz de Queiroz" (ESALQ/USP) e no Laboratório de Biotecnologia Vegetal do Centro de Energia Nuclear na Agricultura (CENA/USP).

\subsection{Material Vegetal}

\subsubsection{Cultivo de calos embriogênicos}

Calos embriogênicos de laranjas 'Valência Rhode Red', 'Ruby Blood', 'Pêra' cv. 158, 'Natal', 'Valência' cv. 63 e 'Succari' (Citrus sinensis L. Osbeck); tangerinas 'Cleópatra' (Citrus reshi Hort. ex Tanaka) e 'Sunki' (Citrus sunki); limão 'Cravo' (C. limonia L. Osbeck); híbridos de tangerina: tangor 'Murcote' (Citrus reticulata x Citrus sinenis) e 'kinnow' (Citrus nobilis $x$ Citrus deliciosa), com aproximadamente 3 anos de cultivo e obtidos de óvulos abortados extraídos de frutos maduros, foram utilizados para isolamento de protoplastos.

O cultivo das linhagens de calo foi realizado em meio de cultura MT semi-sólido (Murashige \& Tucker, 1969), modificado pela adição de $500 \mathrm{mg} \cdot \mathrm{L}^{-1}$ de extrato de malte, e em ausência de luz. Portanto, sem acréscimo de regulador vegetal, para minimizar as possibilidades de ocorrência de variação somaclonal ou a supressão do potencial embriogênico dos calos. 
Em intervalos de 30 dias os calos foram subcultivados para meio fresco, utilizando para isto o mesmo meio de cultivo.

\subsubsection{Cultivo de plantas in vitro, a partir de sementes}

Para obtenção das espécies a serem utilizadas como fonte de protoplastos de mesófilo foliar, frutos maduros de laranjas 'Valência' cv. 63 e 'Rubi' (Citrus sinensis L. Osbeck); tangerina 'Cleópatra' (Citrus reshi Hot. ex Tanaka), 'Sunki' (Citrus sunki Hort. ex Tanaka), 'Poncãn' (Citrus reticulata Blanco) e 'Mexerica Rio' (Citrus deliciosa Tenore); limão 'Volkameriano' (Citrus Volkameriana, Pasquale); Fortunella obovata, Tanaka e citrumelo 'Swingle' (Poncirus trifoliata x Citrus paradisi) foram colhidos, lavados com água corrente e cortados ao meio para a extração das sementes.

No sentido de acelerar a germinação in vitro, retirou-se o tegumento das sementes e, posteriormente, procedeu-se a desinfestação das mesmas, utilizando hipoclorito de sódio na concentração de 2:1 (v:v:).

O cultivo foi realizado em meio de cultura RMAN (Grosser \& Gmitter Junior, 1990a), sem a adição de regulador vegetal, para germinação e conseqüentemente desenvolvimento de plântulas, à temperatura de $27 \pm 1{ }^{\circ} \mathrm{C}$, com fotoperíodo de 16 horas luz.

\subsection{Eficiência de isolamento de protoplastos de calos embriogênicos, em diferentes soluções enzimáticas}

A obtenção de protoplastos íntegros, livres de restos celulares, bem como a eficiência de plaqueamento, são condições importantes para o sucesso da hibridação somática na regeneração de plantas. Porém, a metodologia não pode ser generalizada, pois cada genótipo é um caso 
particular, necessitando alguns ajustes específicos. Neste sentido, foram conduzidos experimentos preliminares de isolamento e plaqueamento de protoplastos dos parentais embriogênicos a serem utilizados na hibridação somática.

Para 0 isolamento de protoplatos das linhagens de calo embriogênicos foram utilizadas três soluções enzimáticas: 1. Grosser \& Chandler (1987), composta de $1 \%$ celulase Onozuka R.S (Yakulu Honsha), 1\% macerase R-10 (Yakult Honsha) e 0,2\% pectolyase Y-23 (Seishin); dissolvidas em solução de $0,7 \mathrm{M}$ manitol, $24,5 \mathrm{mM} \mathrm{CaCl} \mathrm{CH}_{2} \mathrm{O}$; 0,92 $\mathrm{mM} \mathrm{NaH} \mathrm{PO}_{4}$ e 6,15 mM de ácido 2-[N-morfolino]-etanossulfônico (MES) (Grosser \& Gmitter Junior 1990b), utilizando-se $2 \mathrm{~mL}$ desta solução por placa de isolamento, diluído em $2 \mathrm{~mL}$ de meio $\mathrm{BH}_{3} \quad 0,7 \mathrm{M}$ (Mourão Filho, 1995); 2. Kobayashi et al. (1983), constituída de 0,2 \% celulase Onozuka R-10, $0,3 \%$ de macerozyne R-10 e $0,1 \%$ driselase (Kyowa Hakko Kogyo), dissolvidas em solução com metade dos macroelementos do meio de cultura MT e $0,7 \mathrm{M}$ de manitol, utilizando 5 $\mathrm{mL}$ desta solução por placa de isolamento e 3. Ochatt et al. (1987), composta por: $1 \%$ celulase Onozuka R-10; $0,2 \%$ macerase $\mathrm{R}-10$ e $0,1 \%$ driselase dissolvidas em CPW 13M (Freason et al., 1973) com 5 mM MES, utilizando-se $10 \mathrm{~mL}$ da solução em cada placa de isolamento.

$\mathrm{O} \mathrm{pH}$ das soluções enzimáticas foi ajustado para 5,7 e a seguir, as mesmas foram esterilizadas por meio de filtro-esterilização.

Aproximadamente $500 \mathrm{mg}$ de calo foram colocados em cada placa de Petri (58 X $15 \mathrm{~mm}$ ), juntamente com a solução enzimática, incubandose por 10 horas, sob agitação orbital de $40 \mathrm{rpm}$, em ausência de luz, à temperatura de $27^{\circ} \mathrm{C}$. 


\subsubsection{Purificação}

Após a incubação do material vegetal na solução enzimática, os protoplastos foram purificados em gradiente de sacarose-manitol. Para este processo, a mistura enzimática contendo os protoplastos foi filtrada em peneira de nylon com malha de $50 \mu \mathrm{m}$, e centrifugada por 5 minutos a $100 \mathrm{~g}$, para remoção de restos celulares não digeridos. O sobrenadante foi removido com pipeta de Pasteur e o "pellet" cuidadosamente ressuspendido em $5 \mathrm{~mL}$ de meio $\mathrm{CPW}$ contendo sacarose a $25 \%$. Dois mililitros de meio CPW com manitol a $13 \%$ foram cautelosamente colocados na parte superior da solução ressuspendida anteriormente, para formar um gradiente de densidade. Os tubos foram centrifugados por 6 minutos a $100 \mathrm{~g}$. Os protoplastos foram removidos e diluídos em $5 \mathrm{~mL}$ do meio $\mathrm{BH}_{3}$ 0,7 M.

A avaliação dos resultados foi realizada com auxílio de câmara de Neubauer, determinando-se o rendimento de protoplastos por peso fresco (grama) de calo. O delineamento experimental utilizado foi inteiramente casualizado em esquema fatorial $3 \times 3 \times 11$, sendo cada repetição constituída por uma placa de isolamento.

\subsubsection{Cultivo de protoplastos: Efeito de diferentes densidades de plaqueamento}

Com o objetivo de avaliar a influência de diferentes densidades na eficiência final de cultivo de protoplastos, os melhores tratamentos resultantes do experimento anterior foram cultivados em cinco densidades $2 \times 10^{4} ; 5 \times 10^{4} ; 10^{5} ; 2 \times 10^{5}$ e $3 \times 10^{5}$ protoplastos. $\mathrm{mL}^{-1}$, em meio de cultura líquido EME $0,7 \mathrm{M}$ na ausência de luz, a temperatura $25 \pm 1{ }^{\circ} \mathrm{C}$ (Grosser \& Gmitter Júnior, 1990b; Mourão Filho, 1995). 
Após 30 dias de cultivo, foram adicionadas às microcolônias 10 a 12 gotas do meio de cultura 1:1:1 (v:v:v), com o objetivo de reduzir 0 potencial osmótico do meio, composto de 1 parte de $\mathrm{BH}_{3}$ 0,6 M, 1 parte de EME $0,6 \mathrm{M}$ e 1 parte de EME $0,146 \mathrm{M}$, e transferidos para sala de crescimento, sob fotoperíodo de 16 horas luz. Em subcultivos posteriores (a cada 20-30 dias), quando a cultura de protoplastos já estava mais vigorosa, formando microcalos, adicionou-se às microcolônias o meio de cultura 1:2 (v:v), o qual é composto por 1 parte do meio de cultura $\mathrm{BH}_{3}$ $0,6 \mathrm{M}$ e 2 partes EME 0,146 M.

Aos 90 dias de cultivo, foi avaliado o número de microcalos desenvolvidos, com aproximadamente 1-2 mm, transferido-os para placa de Petri $(100 \times 15 \mathrm{~mm})$ contendo o meio de cultura semi-sólido EME, suplementado com $25 \mathrm{~g} . \mathrm{L}^{-1}$ de sacarose, a qual foi dividida em 8 campos, para facilitar a contagem das colônias.

0 delineamento experimental utilizado foi inteiramente casualizado, com 3 repetições, sendo cada repetição constituída por uma placa de isolamento.

\subsection{Embriogênese somática: cultura de microcalos, calos e regeneração de plantas}

Os microcalos originados do cultivo de protoplastos foram transferidos para meio EME com $25{\mathrm{~g} . ~ \mathrm{~L}^{-1}}^{-1}$ e sacarose para a indução da embriogênese somática. Os embrióides em estádio globular e com coloração verde foram transferidos isoladamente para meio de cultura fresco, a cada 3 a 4 semanas, com 0 objetivo de promover 0 desenvolvimento até o estádio de embrião cotiledonar.

Os embriões cotiledonares, isto é, que apresentaram cotilédones e eixo radicular incipiente foram transferidos para o meio de cultura EME, 
com 25 gramas de sacarose e suplementado com $2 \mu \mathrm{M}$ de $G_{3}$, para germinação.

Após a germinação, as plantas regeneradas foram individualizadas e transferidas para meio RMAN (Grosser \& Gmitter Junior, 1990a) para promover o enraizamento.

\subsection{Hibridação somática}

Os parentais utilizados nos experimentos de hibridação somática (Tabela 1) foram escolhidos por apresentarem caracteristicas agronômicas potencialmente úteis para o desenvolvimento de novos genótipos a serem integrados em programas de melhoramento de citros. O limão 'Cravo' e limão 'Volkameriano' são muito utilizados como porta enxertos na citricultura brasileira, por produzirem árvores vigorosas, são tolerantes à seca, ao vírus da tristeza, a CVC e induzem boas qualidades de frutos às copas neles enxertadas, porém com alta susceptibilidade ao declínio (Pompeu Junior, 1991), fato que limita sua ampla utilização nas mais diversas regiões citrícolas. As tangerinas 'Cleópatra', 'Sunki' e 'Kinnow' têm sido uma alternativa na diversificação de porta-enxertos, devido a tolerância ao declínio, tristeza e CVC. Árvores enxertadas em tangerina 'Cleópatra' e 'Sunki' são moderadamente vigorosas, embora mais tardias na entrada da produção comparado aos porta-enxertos mencionados acima (Pompeu Junior 1991). Laranjas doces são tolerantes ao declínio, porém são pouco utilizadas como porta-enxerto devido apresentar susceptibilidade a Phytophthora (Louzada, 1992). Poncirus trifoliata e citrumelo 'Swingle', embora não apresentem produções semelhantes às do limão 'Cravo' vêm demonstrando bom potencial para locais favoráveis a ocorrência de Phytophthora ou para plantios adensados. Os frutos sobre eles produzidos apresentam caracteristicas superiores aos frutos produzidos sobre o limão 'Cravo'. Os testes 
Tabela 1. Combinações envolvidas nos experimentos de hibridação somática.

Parentais embriogênicos

Parentais não embriogênicos

\begin{tabular}{lll}
\hline Tangerina 'Cleópatra' & + & limão 'Volkameriano' \\
Tangerina 'Kinnow' & + & limão 'Volkameriano' \\
Laranja 'Valência Rohde Red' & + & limão 'Volkameriano' \\
Laranja 'Ruby Blood' & + & limão 'Volkameriano' \\
Laranja 'Valência' cv. 63 & + & Fortunella obovata \\
Limão 'Cravo' & + & Poncirus trifoliata \\
Limão 'Cravo' & + & citrumelo 'Swingle' \\
Limão 'Cravo' & + & tangerina 'Sunki' \\
Laranja 'Pêra' cv. 158 & + & limão 'Volkameriano' \\
Tangerina 'Kinnow' & + & laranja 'Valência' cv. 63 \\
Tangerina 'Kinnow' & + & laranja 'Rubi' \\
Laranja 'Valência Rohde Red' & + & tangerina 'Cravo' \\
Laranja 'Succari' & + & tangerina 'Cravo' \\
Laranja 'Valência' cv. 63 & + & tangerina 'Poncãn' \\
Laranja 'Valência Rohde Red' & + & tangerina 'Poncãn' \\
Laranja 'Natal' & + & tangerina 'Poncãn' \\
Laranja 'Ruby Blood' & + & tangerina 'Poncãn' \\
Laranja 'Ruby Blood' & + & tangerina 'Mexerica \\
\hline
\end{tabular}


realizados com Poncirus trifoliata mostram que estes são suscetiveis ao declínio, enquanto o citrumelo 'Swingle' é tolerante a este distúrbio fisiológico (Pompeu Junior, 1991). Quanto a Fortunella obovata, Tanaka, este foi escolhido devido ao seu potencial no melhoramento de citros, pois apresenta resistência ao frio, induz precocidade de produção (Rahman \& Nito, 1993) e possui resistência à CVC (Li, 1997).

\subsubsection{Fusão e plaqueamento dos protoplastos}

Para a fusão de protoplastos misturou-se igual volume de produto da purificação de cada fonte parental. Colocou-se duas gotas da mistura de protoplastos no centro de uma placa de Petri descartável $58 \times 15 \mathrm{~mm}$ e adicionaram-se duas gotas da solução de $27 \mathrm{mM}$ de polietilinoglicol (PEG) $(P M=1450)$. Esta mistura foi incubada por 8 minutos $e$ posteriormente, procederam-se três lavagens com meio de cultura $\mathrm{BH}_{3}$ 0,7 M. Os protoplastos foram plaqueados na densidade de $10^{5}$ protoplastos. $\mathrm{mL}^{-1}$ em meios de cultura líquidos $\mathrm{BH}_{3} 0,7 \mathrm{M}$, EME $0,7 \mathrm{M} \mathrm{e}$ $\mathrm{BH}_{3}$ 0,7 M/EME $0,7 \mathrm{M}(\mathrm{v} / \mathrm{v})$ e incubados na ausência de luz à temperatura de $27^{\circ} \mathrm{C}$, (Mourão Filho 1995; Grosser \& Gmitter Junior, 1990b).

A solução enzimática de Grosser \& Chandler (1987) foi utilizada para 0 isolamento de protoplastos de células do mesófilo foliar e calos embriogênicos.

Os procedimentos para o cultivo de protoplastos, indução da embrigênese somática e regeneração de plantas, foram realizados de forma semelhante aos descritos no item 3.3.

\subsubsection{Aclimatização das plantas}

Plantas enraizadas foram adaptadas a condições de casa de vegetação. Estas foram transferidas para vasos contendo substrato 
comercial Plantmax TM Citrus. Com o objetivo de manter a umidade relativa alta, as plântulas foram cobertas com saco plástico, o qual era retirado aproximadamente 2 vezes ao dia por 10 minutos. A freqüência e o tempo de retirada do saco plástico foram aumentados gradativamente à medida que as plantas demonstraram maior controle do processo transpiratório, o qual pode ser visualizado quando as mesmas não apresentaram sintomas de murchamento, adaptando-se ao ambiente.

0 processo de aclimatização durou aproximadamente 30 a 45 dias, dependendo da qualidade do material in vitro. Após esse período, as plantas foram transferidas para vasos contendo substrato comercial misturado com adubo Osmocote TM mais micronutrientes na formulação 22-4-8 (60 Kg do substrato comercial e $320 \mathrm{~g}$ do adubo) e mantidas em telado. Todas as plantas regeneradas foram aclimatizadas.

\subsection{Confirmação da hibridação}

\subsubsection{Identificação de plantas poliplóides}

\subsubsection{Análise estomática}

De cada planta híbrida e de seus respectivos parentais, foram coletadas cinco folhas jovens da porção terminal dos ramos de plantas mantidas em casa de vegetação. As folhas foram cortadas em discos com diâmetro de $1 \mathrm{~cm}$, fixadas em glutaraldehyde $2 \%$, desidratação em uma série de etanol (35-100\%) e secas ao ponto crítico por $\mathrm{CO}_{2}$ (Rodriguez \& Wetzstein, 1998). As amostras foram então montadas em "stubs" de alumínio de $13 \mathrm{~mm}$, cobertas com ouro durante 180 segundos. As observações e eletromicrografia foram realizadas em microscópio de varredura LEO $435 \mathrm{VP}$ operando a $10 \mathrm{kV}$. 
A análise foi conduzida determinando-se o tamanho e número de estômatos por campo da epiderme abaxial com ampliação de 700 vezes, correspondendo a uma área de $0.1213 \mathrm{~mm}^{2}$. O tamanho dos estômatos foi medido considerando-se 5 estômatos por campo. A contagem e o tamanho dos estômatos foram determinados em dez campos de cada amostra, cinco amostras de cada planta, totalizando 50 campos por planta diplóide ou poliplóide. A análise estatística incluiu análise de variância dos dados, e as médias foram comparadas pelo teste de Tukey (SAS, 1988), a $1 \%$ probabilidade.

Estas análises não foram realizadas para as combinações de laranja 'Valência' + Fortunella obovata, Tanaka e limão 'Cravo '+ tangerina 'Sunki', pois as plantas, já haviam sido aclimatizadas e confirmadas a hibridização somática por RAPD, não justificando assim a aplicação da técnica para o que ela se propõe.

\subsubsection{Análise citológica}

A contagem do número de cromossomos em células meristemáticas de pontas de raiz mitoticamente ativas das plantas regeneradas foi realizada de acordo com a metodologia descrita por Vieira (1988). Pontas de raíz em crescimento foram coletadas pela manhã, e imersas em solução de 8-hidroxiquinolina 0,002 M por três horas à temperatura ambiente. Após este período o material foi fixado em etanol acético 3:1 (v:v), por cerca de dezoito horas e em seguida mantidos em álcool $70 \%$, por quatro horas. Para corar o material, procedeu-se a hidrólise de oito minutos em $\mathrm{HCl} 1 \mathrm{~N}$ a $60^{\circ} \mathrm{C}$ e em seguida tratou-se com reativo de Schiff (fucsina-leuco-básica), por quarenta e cinco minutos. Após lavagem em água corrente as pontas de raiz foram esmagadas em carmin acético a $1 \%$ para o preparo das lâminas. As lamínulas foram removidas em ácido acético a $45 \%$. Após secagem ao ar, 
as lâminas foram montadas em Entellan e observadas em aumento de 1250 vezes. A confirmação da ploidia deu-se pela contagem de cromossomos, $2 n=4 x=36$, em células das plantas analisadas.

\subsubsection{Análise morfológica foliar}

A análise morfológica foliar foi realizada por meio de comparação das características dos parentais e as plantas obtidas por fusão de protoplastos, considerando os aspectos relacionados a espessura, coloração, forma e presença de pecíolo alado.

\subsubsection{Análise de DNA por marcadores RAPD}

Além da análise citológica e foliar, a confirmação da hibridação somática foi concluída com testes de marcadores moleculares, especialmente PCR ('Polymerase Chain Reaction') com uso de "primers" aleatórios (RAPD) (Mourão Filho, 1995).

\subsubsection{Extração de DNA}

Utilizou-se a metodologia de Hoisington et al. (1994), com algumas modificações. Macerou-se 1-2 folhas das plântulas em nitrogênio liquido. O macerado foi colocado em tubos de $1,5 \mathrm{~mL}$ (Eppendorf) com $500 \mu \mathrm{L}$ do tampão de extração CTAB (Tris- $\mathrm{HCl}$ pH7.5,100 mM; NaCl, 700 $\mathrm{mM}$; $\mathrm{Na}_{2}$ EDTA pH 8.0, $50 \mathrm{mM}$; $\beta$-mercaptoetanol, $140 \mathrm{mM} ; 1 \%$ de Brometo de cetiltrimetilamônio (CTAB). Estas amostras foram, então, incubadas em banho-maria a $65^{\circ} \mathrm{C}$, por 1 hora. Após este período os tubos foram retirados do banho-maria, e acrescentou-se $500 \mu \mathrm{L}$ de clorofórmio-álcool isoamílico (24:1), extraindo por 5 minutos. Centrifugou-se a $13000 \mathrm{rpm}$, por 10 minutos, a temperatura de $10^{\circ} \mathrm{C}$. 
O sobrenadante foi transferido para novos tubos e adicionados $500 \mu \mathrm{L}$ de solução clorofórmio-álcool isoamílico (24:1). Os tubos foram agitados com cuidado e novamente centrifugados a $13000 \mathrm{rpm}$ por 10 minutos. A fase aquosa foi transferida para novos tubos, adicionando-se $400 \mu \mathrm{L}$ de etanol absoluto e mantendo-se em freezer $\left(-20^{\circ} \mathrm{C}\right)$ por 10 minutos. Os tubos foram centrifugados por 15 minutos; e o sobrenadante removido. Procedeu-se então uma lavagem do "pellet" com etanol $95 \%$ e $70 \%$ e dissolvido em $50 \mu \mathrm{L}$ de TE (Tris- $\mathrm{HCl}$ pH 7.5, $10 \mathrm{mM}$ e EDTA pH $8.0,1 \mathrm{mM})$.

\subsubsection{Quantificação do DNA}

A quantificação de DNA foi realizada por eletroforese de alíquotas de DNA, comparando-se com uma série de concentrações de DNA do fago $\lambda$ (5 a $80 \mathrm{ng}$ ), em gel de agarose $1 \%(\mathrm{p} / \mathrm{v})$. A concentração de DNA foi estimada a partir da comparação visual da intensidade das bandas, reveladas pela coloração com brometo de etídeo.

O DNA quantificado de cada planta individual foi utilizado nas reações para análise das plantas de cada combinação.

\subsubsection{Seleção de "primers" para utilização nas reações de RAPD}

A seleção de "primers" polimórficos foi realizada a partir de uma avaliação dos produtos de amplificação gerados pelos "primers" OP-1 a OP-20 dos Kits AA, AB e $F$ (Operon Technologies). Inicialmente o DNA amplificado de cada "primer" foi separado em gel de agarose para verificar se havia polimorfismo entre as espécies parentais. A partir desta seleção preliminar, os "primers" que revelaram maior número de fragmentos polimórficos amplificados foram utilizados para confirmação da hibridação somática. 


\subsubsection{Reação de amplificação do DNA}

A reação de $P C R$, ou seja, reação de amplificação de DNA; para cada amostra, foi realizada para um volume final de $20 \mu \mathrm{L}$ contendo: tampão 10x; $\mathrm{MgCl}_{2}, 2.5 \mathrm{mM}$; DNTPs, $2.5 \mu \mathrm{M} ; 100 \mu \mathrm{M}$ de cada "Primers"; 1 unidades de enzima Taq-DNA polimerase (Gbico) e $30 \mathrm{ng}$ de DNA.

As reações de PCR foram realizadas em termociclador (MJ Research, Watertow, MA) com o programa: 1) $93^{\circ} \mathrm{C} / 2 \mathrm{~min}$; 2) $92^{\circ} \mathrm{C} / 1$ $\min$; 3) $37^{\circ} \mathrm{C}$ por $1 \min$; 4) $72^{\circ} \mathrm{C}$ por $2 \min$; 5) $72^{\circ} \mathrm{C}$ por 5 minutos. Etapas 2 a 4 repetidas 43 ciclos.

\subsubsection{Eletroforese e análise}

Após reação de amplificação, realizou-se a eletroforese em gel horizontal de agarose a 1,5\%, em solução tampão TBE (Tris- $\mathrm{HCl} \mathrm{pH} 7.5$, $45 \mathrm{mM}$; ácido bórico, $45 \mathrm{mM}$, e EDTA, $\mathrm{pH}=8.0,1 \mathrm{mM}$ ) com $5 \mathrm{ng}$ de brometo de etídeo por mililitro de gel. 0 gel foi submetido à corrente elétrica constante, de aproximadamente 80 Volts, em solução tampão de TBE $0.5 \mathrm{X}$ por 6 horas, à temperatura ambiente. $O$ padrão de bandas foi examinado e registrado sobre luz ultravioleta. 


\section{RESULTADOS E DISCUSSÃO}

\subsection{Isolamento de protoplastos de calos embriogênicos, em diversas soluções enzimáticas}

Um eficiente sistema de isolamento de protoplastos e, consequentemente, regeneração de plantas é reconhecido como um pré-requisito para o sucesso da hibridação somática. Neste sentido, avaliou-se os efeitos das soluções enzimáticos de Grosser \& Chandler (1987), Ochatt et al. (1987) e Kobayashi et al. (1993) em linhagens de calos embriogênicos com 3 anos de subcultivo.

Os resultados do experimento contrastando as três soluções enzimáticas revelaram que os tratamentos apresentaram efeitos diferentes em relação ao número de protoplastos isolados. $\mathrm{g}^{-1}$ de calo, com grau de confiança superior a $99 \%$ de probabilidade (Tabela 2 ).

Analisando-se o comportamento das diferentes variedades em cada solução enzimática, observa-se que os rendimentos médios de protoplastos. $\mathrm{g}^{-1}$ de calo diferiram entre as espécies estudadas, bem como dentro da mesma espécie. Este efeito da variedade também foi relatado por Mendes-da-Glória (1998), avaliando o rendimento de protoplastos de cinco cultivares cítricas, e por Oliveira et al. (1993) e Latado (1998), ao determinarem uma metodologia para o isolamento de protoplastos de tangerina 'Cleópatra' e limão 'Cravo'. 
Tabela 2. Número de protoplastos. $g^{-1}$ de calo, em 11 variedades cítricas conforme solução enzimática.

\begin{tabular}{lccc}
\hline \multirow{2}{*}{\multicolumn{1}{c}{ Variedades }} & \multicolumn{3}{c}{ Soluções enzimáticas } \\
\cline { 2 - 4 } & $\begin{array}{c}\text { Grosser \& } \\
\text { Chandler }\end{array}$ & Ochatett et & Kobayashi et \\
& $(1987)$ & $(1987)$ & al., \\
& \multicolumn{2}{c}{ Número de protoplastos. g $^{-1}$} & de calo \\
\hline & $4.69 \times 10^{6} \mathrm{aA}$ & $2.78 \times 10^{6} \mathrm{aB}$ & $2.08 \times 10^{6} \mathrm{aC}$ \\
\hline Tangerina 'Cleópatra' & $7.03 \times 10^{6} \mathrm{bA}$ & $5.59 \times 10^{6} \mathrm{bB}$ & $1.81 \times 10^{6} \mathrm{aC}$ \\
Tangerina 'Kinnow' & $10.88 \times 10^{6} \mathrm{cA}$ & $5.16 \times 10^{6} \mathrm{bB}$ & $3.51 \times 10^{6} \mathrm{bC}$ \\
Tangerina 'Sunki' & $17.72 \times 10^{6} \mathrm{dA}$ & $10.8 \times 10^{6} \mathrm{cB}$ & $4.88 \times 10^{6} \mathrm{cC}$ \\
Laranja 'Ruby Blood' & $10.85 \times 10^{6} \mathrm{cA}$ & $4.9 \times 10^{6} \mathrm{~dB}$ & $2.86 \times 10^{6} \mathrm{aC}$ \\
Laranja 'V. Rohde Red' & $7.06 \times 10^{6} \mathrm{bA}$ & $4.8 \times 10^{6} \mathrm{~dB}$ & $2.69 \times 10^{6} \mathrm{aC}$ \\
Laranja 'Pêra' cv. 158 & $14.83 \times 10^{6} \mathrm{eA}$ & $4.9 \times 10^{6} \mathrm{~dB}$ & $3.17 \times 10^{6} \mathrm{bC}$ \\
Laranja 'Natal' & $4.99 \times 10^{6} \mathrm{aA}$ & $1.65 \times 10^{6} \mathrm{eB}$ & $6.87 \times 10^{6} \mathrm{dC}$ \\
Laranja 'Succari' & $19.31 \times 10^{6} \mathrm{fA}$ & $20.99 \times 10^{6} \mathrm{fB}$ & $22.95 \times 10^{6} \mathrm{eC}$ \\
Laranja 'Valência' cv. 63 & $22.68 \times 10^{6} \mathrm{gA}$ & $23.68 \times 10^{6} \mathrm{fB}$ & $19.24 \times 10^{6} \mathrm{fC}$ \\
Limão 'Cravo' & $21.11 \times 10^{6} \mathrm{gA}$ & $19.0 \times 10^{6} \mathrm{fB}$ & $15.18 \times 10^{6} \mathrm{gC}$ \\
\hline Tangor 'Murcote' & 0.940 & 0.940 & 0.940 \\
\hline CV & & &
\end{tabular}

Médias com a mesma letra minúscula na coluna e maiúscula na linha não diferem entre si (Tukey; 0,01) 
Possivelmente estas diferentes respostas estão relacionadas com características inerentes a parede celular que, embora seus constituintes básicos sejam os mesmos, sua composição pode variar muito entre as espécies (Carneiro et al., 1998). Portanto, requisitos metodológicos para o isolamento de protoplastos são exigidos por diferentes espécies e variedades, principalmente no que se refere à enzima de maceração (Schenk \& Hilderbrant 1977; Vardi et al.; 1982; Grosser \& Gmitter Junior 1990b; Carneiro et al., 1998).

A solução enzimática proposta por Grosser \& Chandler (1987) difere das soluções de Ochatt et al. (1987) e Kobayashi et al. (1983), principalmente com relação ao tipo e concentração de enzimas. A comparação dos efeitos promovidos pelas três soluções permitiu concluir que a solução Grosser \& Chandler (1987) foi a mais eficiente no isolamento de protoplastos, fato comprovado pelo melhor comportamento das variedades estudadas, exceto para o limão 'Cravo', em que os melhores rendimentos ocorreram na enzima Ochatt et al. (1987) e as laranjas 'Valência' cv. 63 e 'Succari' na enzima Kobayashi et al. (1983). Resultados semelhantes foram relatados por Benedito et al. (1999), avaliando diferentes soluções enzimáticas no isolamento de protoplastos de calos embriogênicos em 4 variedades de laranjas doces.

No experimento realizado, observou-se a presença de muitos protoplastos desintegrados quando isolados nas enzimas de Ochat et al. (1987) e Kobayashi et al. (1983), mesmo para as variedades de limão 'Cravo', 'Valência' cv. 63 e 'Succari'. Este fato é bastante significativo, especialmente, para o sucesso do cultivo de protoplastos e demonstra que além da eficiência da enzima Grosser \& Chandler (1987), em relação à quantidade de protoplastos isolados, também se destaca quanto à qualidade destes. De acordo Evans \& Bravo (1983), o rompimento da membrana plasmática permite à liberação de compostos fenólicos, os quais, promovem a síntese anormal da parede celular, atraso nas 
divisões e até morte das células, prejudicando portanto, o cultivo de protoplastos íntegros.

\subsection{Cultivo de protoplatos}

O cultivo dos protoplastos purificados foi realizado plaqueando-se os mesmos em meio EME 0,7 M, nas densidades de $2 \times 10^{4}, 5 \times 10^{4}, 10^{5}$, $2 \times 10^{5}$ e $3 \times 10^{5}$ protoplatos. $\mathrm{mL}^{-1}$ no sistema de gotas não solidificadas, como descrito por Grosser \& Gmitter Junior (1990b).

Os melhores resultados, com relação ao número de microcolônias formadas foram obtidos com $10^{5}$ e $2 \times 10^{5}$ protoplastos. $\mathrm{mL}^{-1}$, em que a eficiência de plaqueamento variou de $6 \%$ (tangerina 'Kinnow') a 8,5\% (tangerina 'Sunki') e 7,2\% (tangor 'Murcote') a 9,78\% (tangerina 'Cleópatra') (Figura 1). Estes resultados se encontram dentro dos limites citados por Grosser \& Gmitter Junior (1990b), que variam de 0 a $35 \%$ e Vardi et al. (1975) com 3,6 a 9,0\%.

Galun et al. (1975), avaliando o isolamento e a densidade de plaqueamento para a variedade 'Shamouti' (Citrus sinensis), obtiveram os melhores resultados quanto ao número de colônias na densidade de $10^{5}$ protoplastos. $\mathrm{mL}^{-1}$, em que 4 a $9 \%$ dos protoplastos cultivados exibiram divisão celular. Oliveira (1993) em trabalho com cultivo de protoplastos de tangerina 'Cleópatra' e limão 'Cravo', na densidade de $2 \times 10^{5}$ protoplastos. $\mathrm{mL}^{-1}$ obteve eficiência de cultivo de $9 \%$ e $5 \%$, respectivamente.

No que se refere às densidades de plaqueamento de $2 \times 10^{4}$ e $5 \times$ $10^{4}$ protoplastos. $\mathrm{mL}^{-1}$, poucas colônias se desenvolveram, exceto para as variedades de laranja 'Ruby Blood', 'Valência Rohde Red' e 'Valência' cv. 63. Possivelmente a superioridade apresentada por estes cultivares devese ao maior tamanho dos protoplastos observado, acumulando quantidades superiores de reservas, as quais favorecem a divisão celular 


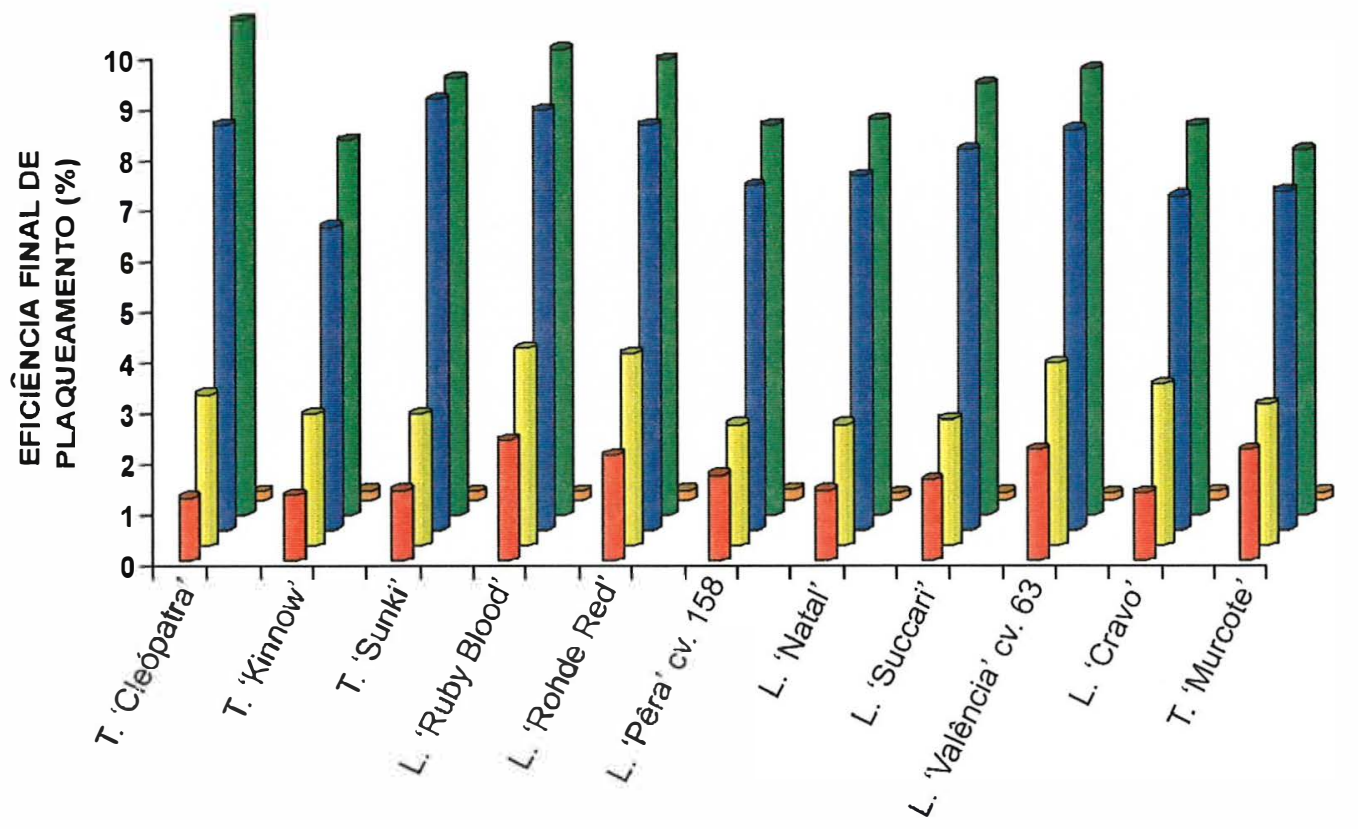

VARIEDADES

DENSIDADE DE PLAQUEAMENTO

$\left(n^{\circ}\right.$ de protoplastos. $\left.\mathrm{mL}^{-1}\right)$

$\square 2 \times 10^{4} \square 5 \times 10^{\circ} \square 10^{5} \square 2 \times 10^{5} \square 3 \times 10^{5}$

Figura 1. Eficiência de plaqueamento (\%), em função da densidade de cultivo ( ${ }^{\circ}$ de protoplastos. $\mathrm{LL}^{-1}$ ), em 11 variedades cítricas. 
em relação às démais cultivares estudadas. Segundo Evans \& Bravo (1983), para cada espécie existe uma densidade mínima de plaqueamento da qual não ocorre divisão celular. Por outro lado, o incremento na densidade para $3 \times 10^{5}$ protoplastos. $\mathrm{mL}^{-1}$ não mostrou comportamento linear. As pouquíssimas colônias desenvolvidas cessaram o crescimento e consequentemente morreram aos 90 dias após o início do cultivo. Resultados semelhantes foram obtidos por Vardi et al. (1975), trabalhando com protoplastos da laranja 'Shamouti', na densidade de $4 \times$ $10^{5}$ protoplatos. $\mathrm{mL}^{-1}$. Em altas densidades, fenômenos de absorção e excreção dos protoplastos podem modificar profundamente o meio de cultura (Carneiro et al., 1998), ocorrendo acúmulo de substâncias tóxicas a niveis letais (Shain, 1985).

\subsection{Embriogênese somática: cultura de microcalos, calos e regeneração de plantas}

As microcolônias oriundas da cultura de protoplastos nas densidades de $2 \times 10^{4}, 5 \times 10^{4}, 10^{5}, 2 \times 10^{5}$ protoplatos. $\mathrm{mL}^{-1}$, foram cultivadas em meio de cultura semi-sólido, suplementado com $25 \mathrm{~g} \cdot \mathrm{L}^{-1}$ de sacarose e mantidos sob condição de baixa luminosidade para o desenvolvimento de calos e embriões.

A freqüência de calos apresentando o desenvolvimento de embriões variaram em função das cultivares $e$ densidade de plaqueamento (Tabela 3 ). Observou-se que as variedades de laranjas foram mais responsivas comparada às tangerinas, limão 'Cravo' e tangor 'Murcote'. Esta última não mostrou capacidade embriogênica em nenhuma densidade de plaqueamento. O efeito da cultivar na capacidade regenerativa foi relatado por outros autores (Kochba et al., 1972; Mourão Filho 1992; Oliveira et al., 1994a; Mendes-da-Glória, 1998; Benedito, 1999; Tomaz, 2000). 
Tabela 3. Indução da embriogênese somática ( $n^{\circ}$ de embriões.placa de Petri) nas linhagens de calo, de 11 variedades cítricas, em diferentes densidades de plaqueamento (avaliação após 30 dias de cultivo).

\begin{tabular}{lcccc}
\hline & \multicolumn{4}{c}{ Densidades de plaqueamento } \\
\cline { 2 - 5 } \multicolumn{1}{c}{ Variedades } & $2 \times 10^{4}$ & $5 \times 10^{4}$ & $10^{5}$ & $2 \times 10^{5}$ \\
\cline { 2 - 5 } & Número de embriões.placa de Petri \\
\hline Tangerina 'Cleópatra' & 0 & 19 & 27 & 11 \\
Tangerina 'Kinnow' & 0 & 11 & 19 & 8 \\
Tangerina 'Sunki' & 0 & 10 & 24 & 6 \\
Laranja 'Ruby Blood' & 0 & 32 & 45 & 15 \\
Laranja 'Valência Rohde Red' & 0 & 30 & 48 & 18 \\
Laranja 'Pêra' cv. 158 & 0 & 18 & 36 & 10 \\
Laranja 'Natal' & 0 & 19 & 34 & 9 \\
Laranja 'Succari' & 0 & 10 & 36 & 6 \\
Laranja 'Valência' cv. 63 & 0 & 35 & 46 & 19 \\
Limão 'Cravo' & 0 & 10 & 22 & 3 \\
Tangor 'Murcote' & 0 & 0 & 0 & 0 \\
\hline
\end{tabular}


Com relação à densidade de plaqueamento e a manutenção da divisão celular, observou-se que as microcolônias resultantes do plaqueamento de $2 \times 10^{5}$ protoplastos. $\mathrm{mL}^{-1}$ desenvolveram calos vigorosos, o que provavelmente desfavoreceu a formação de embriões. Por outro lado, as colônias oriundas da densidade de $2 \times 10^{4}$ protoplastos. $\mathrm{mL}^{-1}$ não apresentaram um ritmo satisfatório de divisão celular. As melhores respostas em relação ao desenvolvimento de embriões foram as colônias oriundas das densidades de plaqueamento de $5 \times 10^{4}$ e $10^{5}$ protoplastos. $\mathrm{mL}^{-1}$. Estas observações revelam que, em densidades muito baixas o ritmo de divisão celular é lento para sustentar o crescimento das colônias. Em contraste, cultivos com densidades elevadas mantêm o ritmo de divisão celular, porém prejudica a embriogênense.

Morfologicamente, observa-se resposta diferenciada na conformação dos embriões formados. O desenvolvimento dos embriões nas variedades de laranjas doces, passaram pelos estádios globular, torpedo e cotiledonar, após 30 dias de incubação dos calos em meio de estímulo a embriogênese. Entretanto, algumas estruturas globulares evoluíram para embriões somáticos mal formados com cotilédones múltiplos, principalmente nas variedades 'Valência Rohde Red' e 'Natal' (Figura 2), os quais não germinaram. Estas diferentes fases de desenvolvimento, foram relatadas por Kunitake \& Mii (1995) em laranja 'Valência', após transferência de embriões somáticos em estádio globular para meio enriquecido com giberelina.

Quanto às variedades de tangerinas, apenas a 'Cleópatra' apresentou desenvolvimento dos embriões somáticos passando pelos estádios acima mencionados. No entanto, alguns embriões anormais foram observados, (Figura 3). Os embriões somáticos formados nas variedades 'Kinnow' e 'Sunki', permaneceram em estádio globular. 
Figura 2. Aspectos morfológicos dos embriões somáticos de laranjas doces desenvolvidos in vitro, após 30 dias de cultivo em meio de germinação. a) embriões somáticos anormal, multicotiledonar (mct), e em estádios globular $(\mathrm{g})$ e torpedo (t) na 'Valência Rohde Red', b) embriões somáticos em estádios globular $(\mathrm{g})$ e cotiledonar $(\mathrm{ct})$ na variedade 'Ruby Blood', c) embriões somáticos em estádios globular ( $g$ ) e torpedo ( $t$ ) na variedade 'Pêra' cv. 158, d) embriões somáticos anormal, multicotiledonar (mct), e em estádio globular na variedade 'Natal', e) embriões somáticos em estádios globular $(\mathrm{g})$ torpedo $(\mathrm{t})$ e cotiledonar (ct) na variedade 'Valência' cv. 63, f) embriōes somáticos em estádios globular (g) e cotiledonar (ct) na variedade 'Succari'. Barra $=200 \mu \mathrm{m}$. 

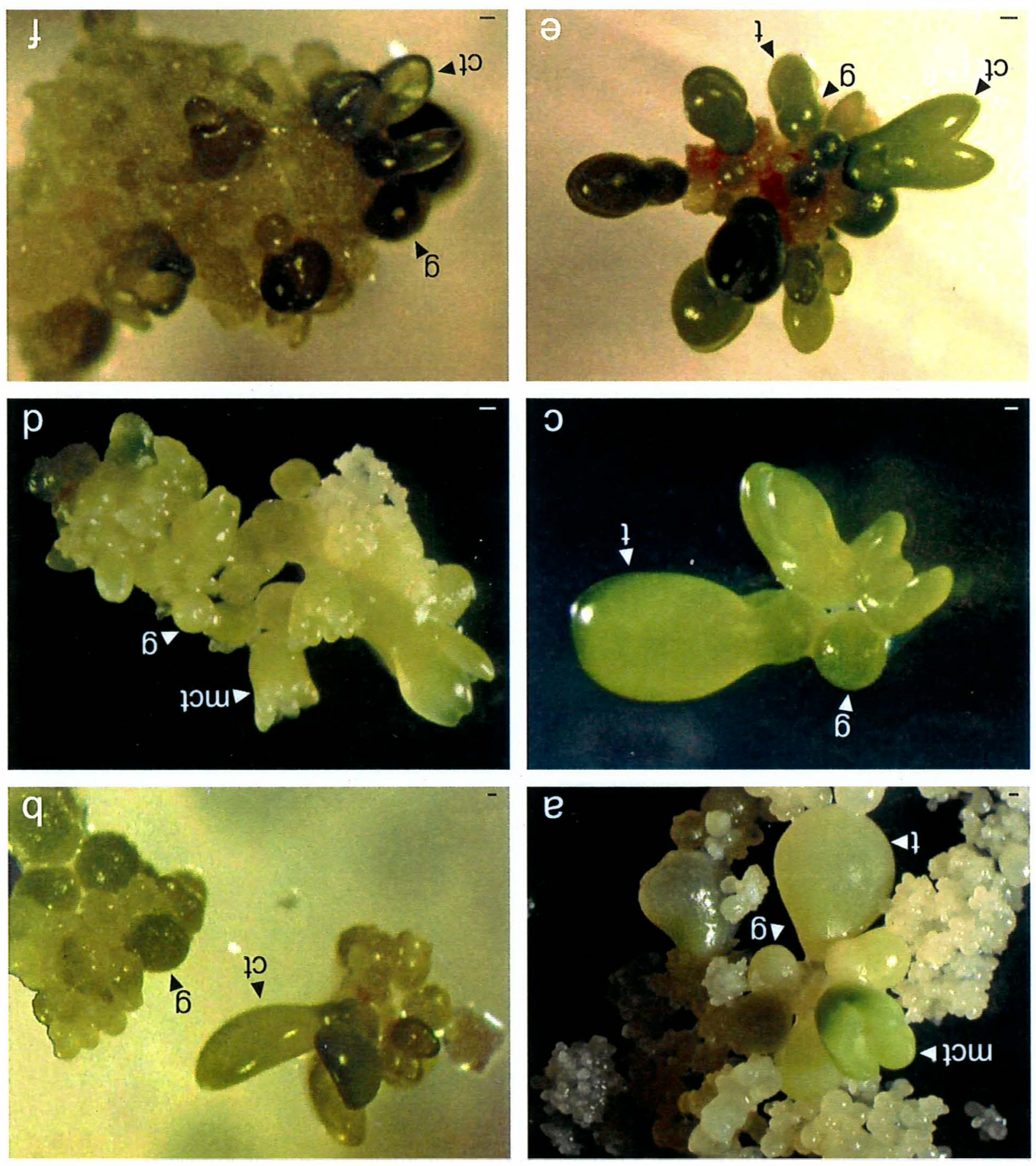


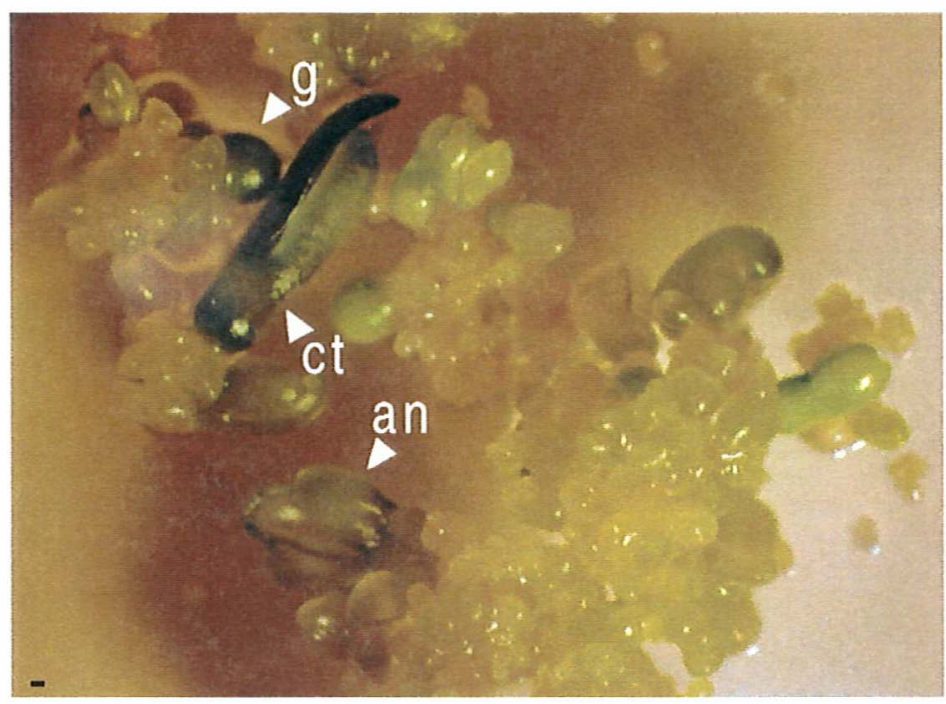

Figura 3. Aspectos morfológicos dos embriões somáticos de tangerina 'Cleópatra' desenvolvidos in vitro, após 30 dias de cultivo em meio de germinação. Embriāo anormal (an), e em estádios globular (g) e cotiledonar (ct). Barra $=200 \mu \mathrm{m}$. 
Variações morfológicas desta natureza têm sido observadas em cultura in vitro de citros e podem ser atribuídas ao genótipo, como verificado por Moore (1985) onde dos vários genótipos estudados, apenas embriões somáticos de limão 'Bears', apresentaram anormalidades (embriões somáticos fusionados). Segundo Schoemaker et al. (1991) o genótipo afeta tanto a frequência quanto o desenvolvimento de embriões somáticos.

Os embriões somáticos desenvolvidos em calos de limão 'Cravo' encontraram-se em estádio globular e partes deles com estrutura multicotiledonar (Figura 4). Resultado semelhante foi relatado por Tomaz (2000) ao estudar a histodiferenciação in vitro da embriogênse somática de citros.

Estudos envolvendo a regeneração de plantas via embriogênese somática in vitro, têm relacionado a baixa conversão em plantas com as anormalidades observadas nos embriões somáticos. Dentre as alterações dos embriões somáticos observadas por diversos autores, estas variam principalmente em relação à morfologia do meristema apical caulinar e dos cotilédones (Westzstein \& Baker 1993; Nickle \& Yeung 1994; Rodriguez \& Wetzstein 1994; Padmanabhan et al., 1998; Passos et al., 1999; Fernando, 1999; Tomaz, 2000).

Os embriões bem definidos das variedades de laranjas doces e tangerina 'Cleópatra' foram transferidos para o meio de germinação semisólido (MT com adição de $2 \mu \mathrm{M}$ de $\mathrm{GA}_{3}$ e $500 \mathrm{mg} \cdot \mathrm{L}^{-1}$ de extrato de malte). Os brotos regenerados foram transferidos para o meio de enraizamento RMAN (Grosser \& Gmitter Junior, 1990a). O completo desenvolvimento dos embriões somáticos e, conseqüentemente, conversão em plantas, foi alcançado quatro meses após cultivo dos embriões em meio de germinação (Tabela 4). 


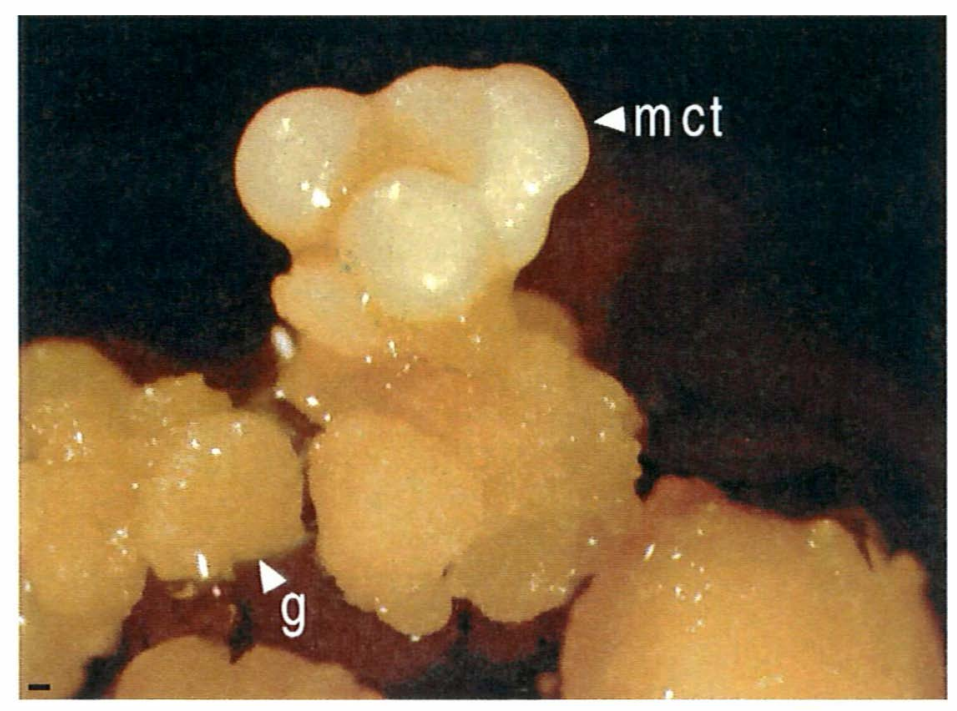

Figura 4. Aspectos morfológicos dos embriões somáticos de limão 'Cravo' desenvolvidos in vitro, após 30 dias de cultivo em meio de germinação. Embrião anormal, multicotiledonar $(m c t)$, e em estádio globular $(g)$. Barra $=200 \mu m$. 
Tabela 4. Número de plantas regeneradas, após 120 dias de cultivo, dos embriões somáticos em meio de cultura de germinação.

Variedades

Número de plantas regeneradas

\begin{tabular}{lc}
\hline Tangerina 'Cleópatra' & 22 \\
Laranja 'Ruby Blood' & 28 \\
Laranja' Valência Rohde Red' & 25 \\
Laranja 'Pêra' cv. 158 & 18 \\
Laranja 'Natal' & 12 \\
Laranja 'Succari' & 5 \\
Laranja 'Valência' cv. 63 & 26
\end{tabular}




\subsection{Hibridação somática em citros}

Fusões de protoplastos envolvendo a tangerina 'Cleópatra', laranjas 'Valência Rohde Red' e 'Ruby Blood' resultaram na formação de alto número de embriões, aproximadamente 90 dias após cultivo, ainda na placa de fusão, os quais apresentaram morfologia normal passando pelos diferentes estádios de desenvolvimento e plantas prontas para aclimatização 9 meses após fusão. A formação de embriões somáticos a partir de microcolônias, foi relatado também por Kobayashi et al. (1983) na cultura de protoplastos de laranja 'Trovita' (Citrus sinensis).

Diferenças no comportamento dos parentais embriogênicos também foram observadas nas fusões de limão 'Cravo' + Poncirus trifoliata e limão 'Cravo' + citrumelo 'Swingle'. Observou-se rápido desenvolvimento das microcolônias, formação de embriões, no entanto sem a ocorrência da histodiferenciação, mesmo quando transferidos para meio de germinação. Consequentemente, não houve conversão em plantas. Possivelmente, a continuidade do processo embriogênico deveuse a alterações genéticas decorrente do processo de fusão elou cultura de tecidos. A combinação de genomas não aparentados pode ocasionar a eliminação de cromossomos paternos, impedindo o desenvolvimento de híbridos somáticos (Barbosa, 1998). Em brássicas, Sundenberg \& Glimelius (1991) encontram uma correlação entre a frequência de híbridos com eliminação cromossômica e a divergência genética. Os autores sugerem que o fenômeno pode estar associado à duração do ciclo celular. Enquanto ocorre a síntese de DNA de um dos genomas no núcleo do híbrido, o outro genoma pode ainda não estar se duplicando. Assim, a segregação cromatídica pode ficar prejudicada, levando a ocorrência de perda cromossômica. Este não-sincronismo do ciclo celular e também do tempo de duração de cada fase da mitose pode ser maior à medida que aumenta a divergência das espécies envolvidas. 
Quanto à fusão de limão 'Cravo' + tangerina 'Sunki', estas apresentaram um desenvolvimento rápido, porém com crescimento de calo extremamente vigoroso, com microcolônias visiveis a olho nu após 30 dias de incubação, o que resultou numa massa de calo bastante grande e um baixo número de embriões, mesmo quando transferidos para meios de cultura com fontes de carbono alternativas, tais como, galactose e maltose nas concentrações de $75 \mathrm{mM}$ e $0,145 \mathrm{M}$, respectivamente.

$\mathrm{Na}$ combinação envolvendo o parental Fortunella obovata os protoplastos e células apresentaram rápido crescimento e baixo número de embriões. Apesar desta combinação envolver gêneros distintos, a taxa de germinação dos embriões foi bastante alta, não sendo observado desenvolvimento anormal dos mesmos, de modo que 7 meses após 0 início do cultivo de protoplastos, plantas foram regeneradas. Demonstrando que apesar de envolver gêneros correlatos, houve uma completa interação genômica dos gêneros, ratificando a importância da interação do material genético dos parentais envolvidos no processo de embriogênese somática.

A combinação de laranja 'Pêra' cv. 158 + limão 'Volkameriano', mostrou-se altamente embriogênica, resultando no desenvolvimento de 30 plantas. No entanto, ocorreu a formação de necroses no colo das mesmas e consequente morte. Este comportamento pode ter ocorrido devido à incompatibilidade natural que existe entre estas duas espécies. Fusões de tangerina 'Kinnow' + limão 'Volkameriano' apresentaram um desenvolvimento rápido e um grande número de embriões deformados. Para induzir o desenvolvimento de parte aérea, os embriões foram cortados e colocados em meio MT suplementado com 50 g. $\mathrm{L}^{-1}$ de sacarose e 13,3 $\mu \mathrm{M}$ de BAP. As plantas formadas não enraizaram, mesmo quando transferidas para meio de enraizamaneto com diferentes tipos e concentrações de auxina $\left(0.5,1.0\right.$ e $1.5 \mathrm{~g} . \mathrm{L}^{-1}$ de ANA ou AIA), e portanto não foram aclimatizadas. Isto nos leva a crer, que a rota de 
desenvolvimento destas plantas ocorreu via organogênese pela formação de gemas na superfície dos cotilédones deformados, em detrimento a embriões. Louzada et al. (1992) reportaram a regeneração de híbridos somáticos por organogênese, pela transferência de segmentos de embrião das combinações tangerina 'Cleópatra' + limão 'Cravo' e laranja azeda + limão 'Volkameriano' para meio de cultura com BAP. Mourão Filho (1995) relatou a regeneração de plantas via organogênese em fusões envolvendo 'Iaranja doce 'Succari' + Clausena lansiun e tangor 'Murcote' + Clausena Iansiun em meio CW-32.

Com relação às fusões para melhoramento de copa, buscou-se combinar laranjas doces com tangerinas em nível tetraplóide, com o objetivo de produzir, em etapas posteriores, plantas com frutos sem sementes e resistentes à CVC, uma vez que as tangerinas apresentam tolerância a esta doença.

Os protoplastos, após a fusão envolvendo tangerina 'Kinnow' com laranjas doces, apresentaram bom desenvolvimento, resultando em microcolônias e formação de embriões. Porém as plantas desenvolvidas foram mal formadas, com caule bastante alongado, mesmo na ausência de $\mathrm{GA}_{3}$ em detrimento a formação de folhas, morrendo antes do processo de aclimatização. Este mesmo comportamento ocorreu na combinação de Iaranja 'Valência Rohde Red' + tangerina 'Cravo' e laranja 'Succari' + tangerina 'Cravo'. Segundo Evans (1983), embora a fusão de protoplatos seja um processo inespecífico, nem todas as combinações de genótipos resultam na formação de plantas normais. Este problema deve-se a uma possivel incompatibilidade somática dos genótipos.

No caso das fusões envolvendo laranjas com tangerina 'Poncãn' e 'Mexerica Pernambucana', devido à ausência do desenvolvimento de embriões, os microcalos foram transferidos para meios EME com novas fontes de carbono e/ou reguladores de crescimento. Os diferentes meios testados foram: $\mathrm{EME}+0,145 \mathrm{M}$ de lactose (Kocba et al., 1978); EME + 
0,145 M de maltose (Mendes-da Glória,1998); EME + $75 \mathrm{mM}$ de galactose (Benedito, 1999). O regulador de crescimento utilizado foi o BAP, por induzir diferenciação celular (Salisbury et al., 1994), na concentração de 13,3 нM (Mourão Filho, 1995). Os calos foram subcultivados a cada 4 semanas, para meio fresco, por um período de 6 meses, com avaliações mensais.

A embriogênese somática ocorreu nos meios $E M E+$ maltose + $\mathrm{BAP}$ e EME + galactose + BAP (Tabela 5). Entretanto, para todos os meios testados, em geral os embriões apresentaram oxidados, baixo vigor e aberrações morfológicas no desenvolvimento. Os embriões que melhor desenvolveram foram transferidos para meio de germinação, contudo não houve conversão em plantas.

Em função dos dados apresentados, observou-se que a fonte de carbono no meio de cultura está relacionada com a indução da embriogênense. Segundo Davies (1995) o efeito é atribuído à inibição da biosintese de auxina. Epstein et al. (1977) observaram que ocorre o acúmulo de auxinas conjugadas com aspartato em células embriogênicas de laranja doce, enquanto isto não ocorre com as não embriogênicas

\subsection{Aclimatização}

Plantas bem desenvolvidas, apresentado de $5-7 \mathrm{~cm}$ de altura, foram aclimatizadas em casa de vegetação. Inicialmente, as plantas foram transferidas para condição de alta umidade e baixa luminosidade, adaptando-se gradativamente para condições normais de luz, umidade e temperatura, por um período de 2 a 3 meses. A aclimatização das plantas é uma etapa crítica, fato comprovado pelo pequeno número de plantas que sobreviveram ao processo (Tabela 6 ). 


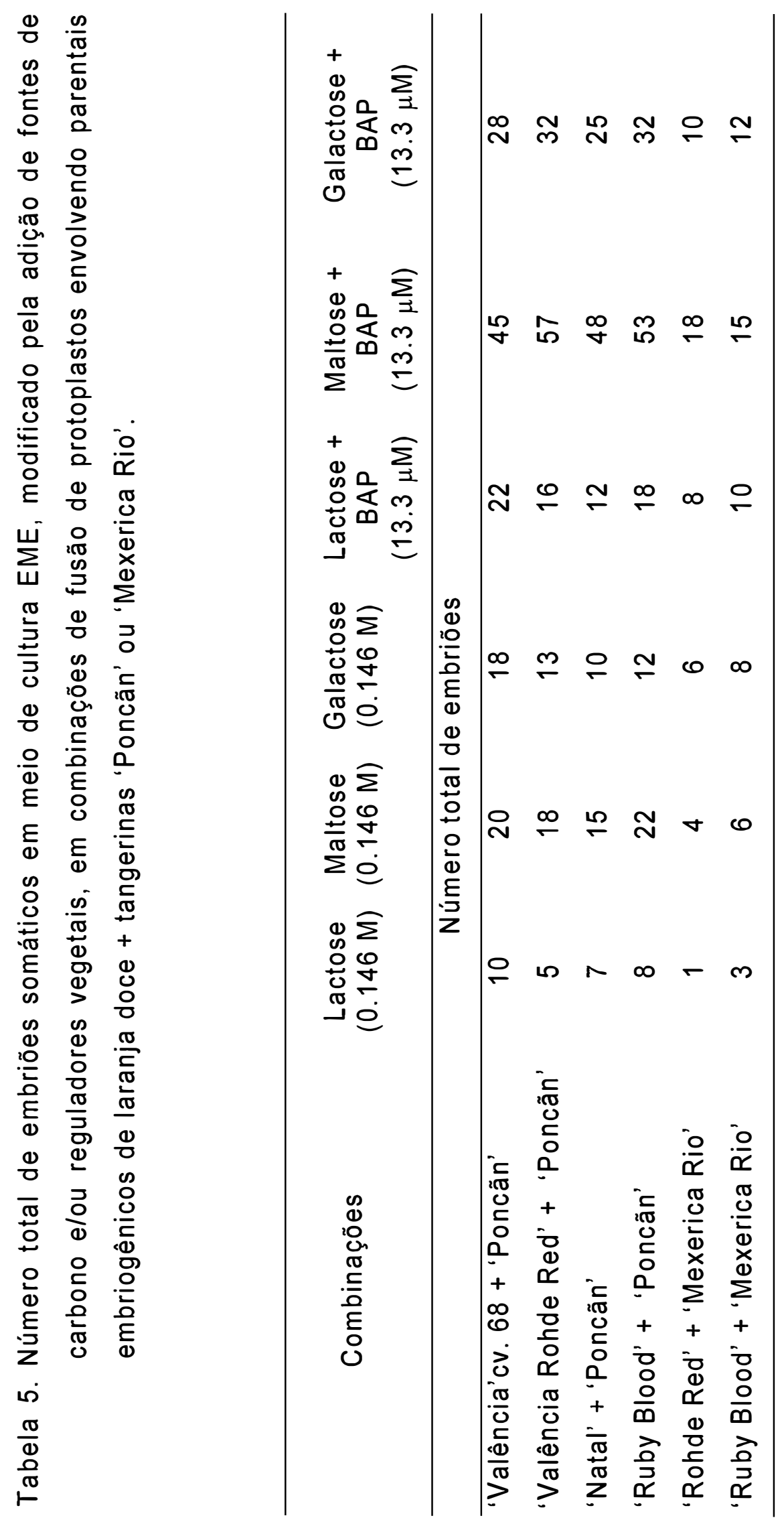




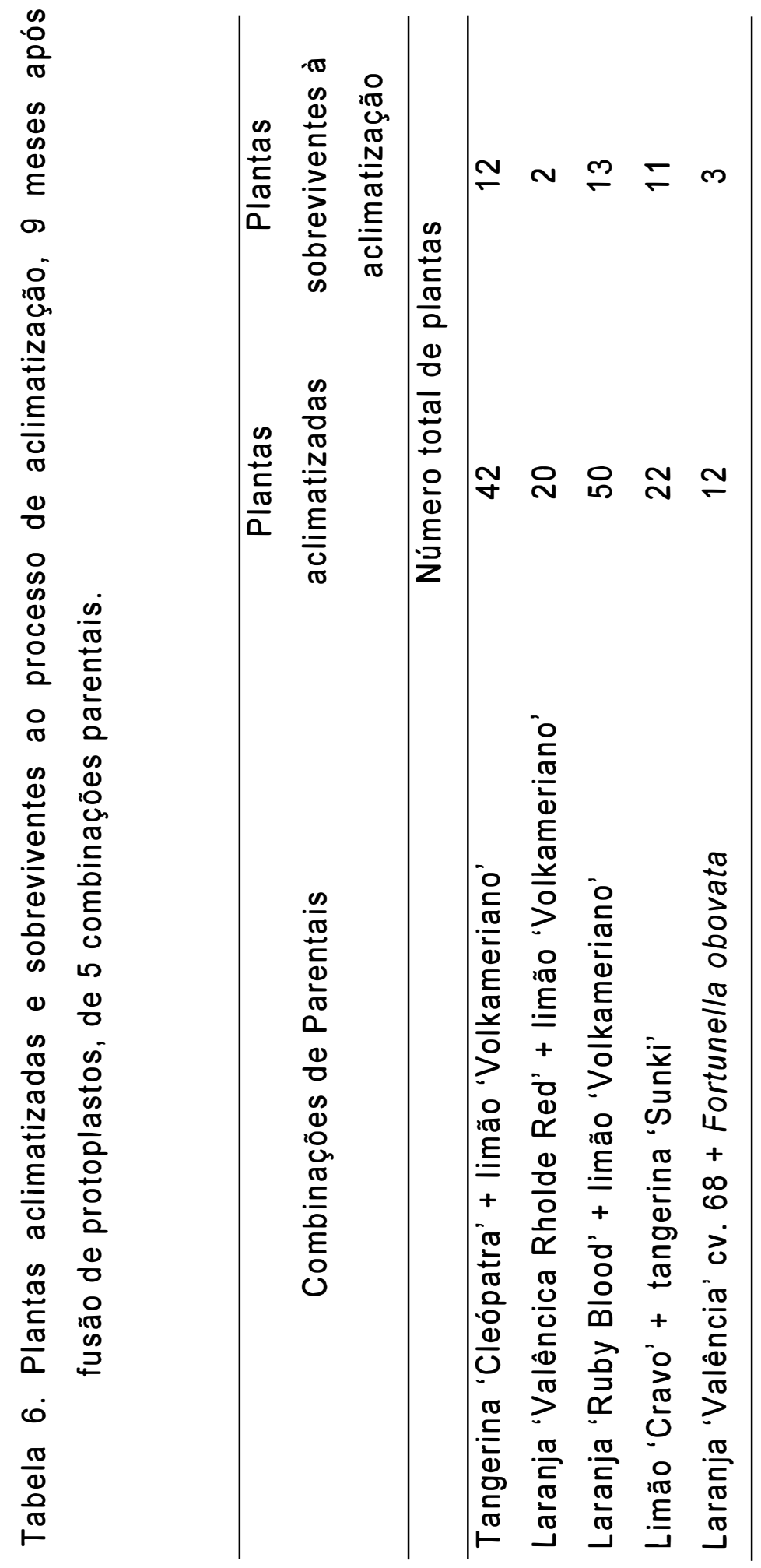




\subsection{Confirmação da hibridação somática}

Todas as plantas que sobreviveram ao processo de aclimatização foram analisadas para caracterização da hibridação somática.

\subsubsection{Efeito da ploidia nas células da epiderme foliar dos produtos de fusão}

Observações da epiderme abaxial das folhas no microscópio eletrônico confirmaram as diferenças no número e tamanho dos estômatos entre os parentais diplóides e respectivos produtos de fusão (Figuras $5,6,7$ ). Os parentais diplóides apresentaram números mais elevados de estômatoslárea e menor tamanho quando comparado ao produto de fusão (Figuras 8 e 9 ).

De acordo com Cutter (1986), o tamanho e a freqüência de estômatos são afetados pelo nivel de ploidia da planta. Em poliplóides, os estômatos são maiores e menos freqüentes, mostrando alta correlação negativa entre estes parâmetros. Resultados semelhantes foram relatados por Suzuki (1981) ao analisar plantas com ploidia diferentes em tabaco e boca de leão, e Barbosa (1998) quando da confirmação do caráter tetraplóide em hibridos somáticos de Passiflora spp. Dornelas (1995) utilizou destes mesmos parâmetros para avaliar plantas de Passiflora spp cultivadas em diferentes fontes de auxinas. O método usado por Barbosa (1998) e Dornelas (1995) requer a remoção da epiderme como parte da preparação de amostra.

A utilização da análise estomática torna-se uma ferramenta importante para identificação precoce de indivíduos poliplóides, pois é uma técnica de fácil execução, constituída da análise de tamanho e/ou número de estômatos por microscopia. Assim, é possivel a realização de uma seleção das plantas regeneradas in vitro, com economia de tempo e 

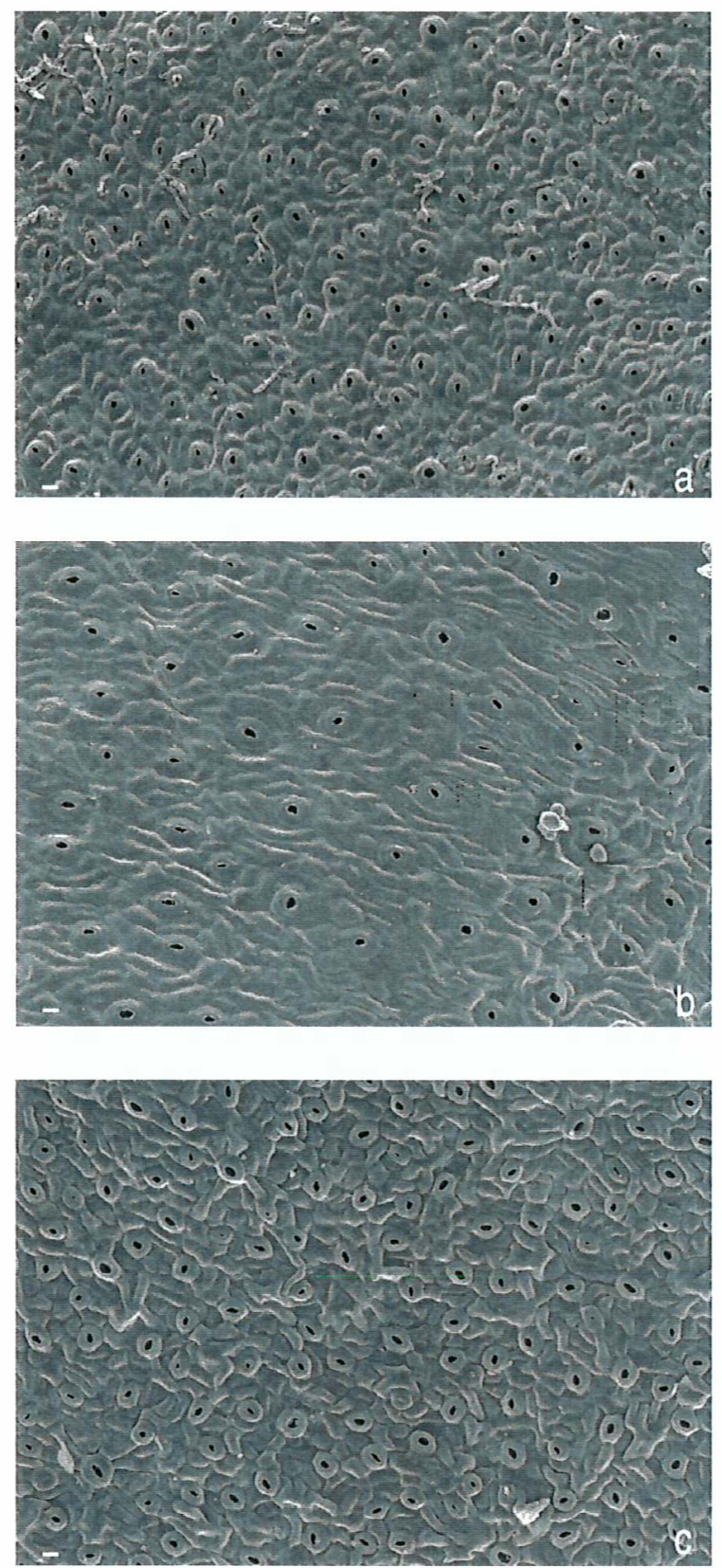

Figura 5. Epidermes foliares abaxiais de plantas diplóides e do respectivo produto de fusão de protoplastos. a) tangerina 'Cleópatra', b) tangerina 'Cleópatra' + limão 'Volkameriano', c) limão 'Volkameriano'. Barra $=10 \mu \mathrm{M}$. 

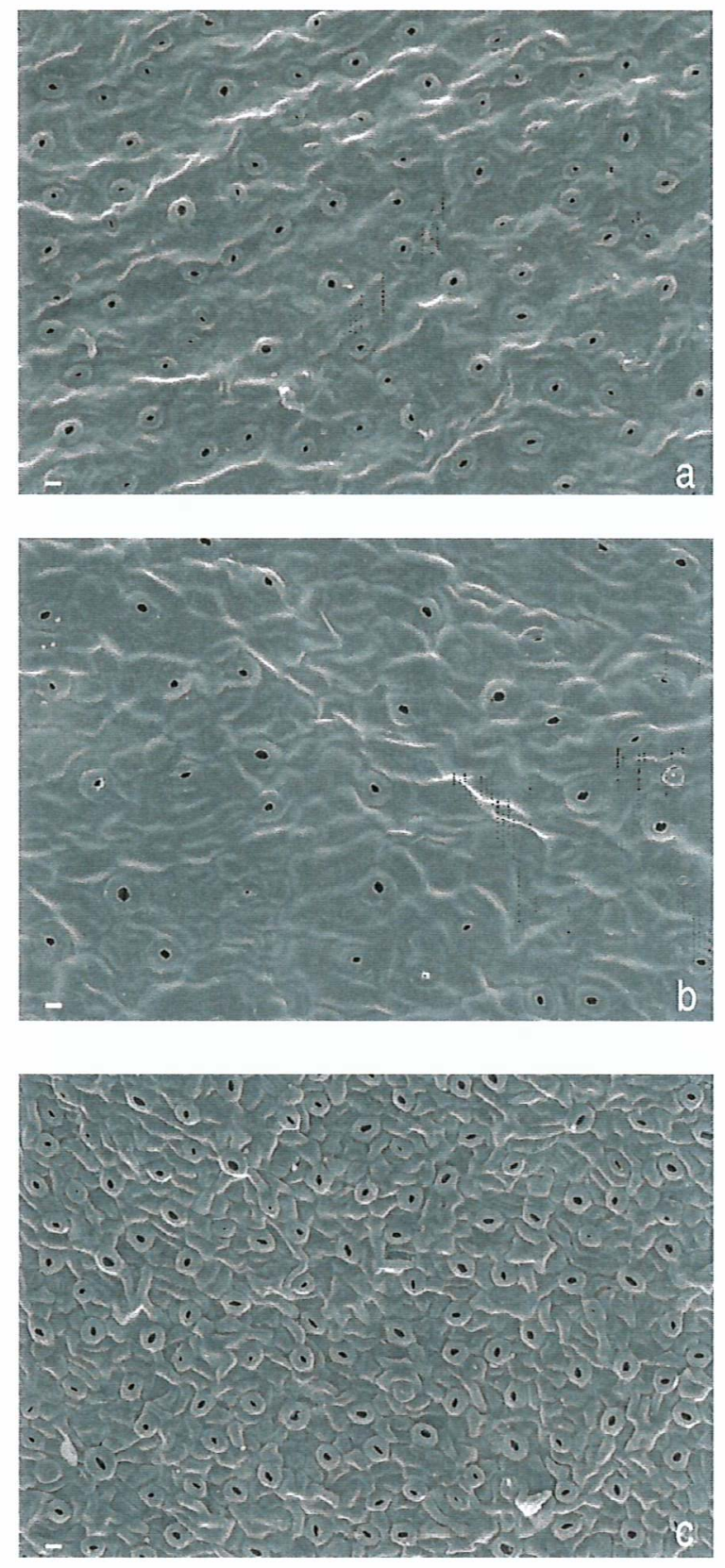

Figura 6 Epidermes foliares abaxiais de plantas diplóides e do respectivo produto de fusão de protoplastos. a) laranja 'Valência Rohde Red', b) laranja 'Valência Rohde Red' + limão 'Volkameriano', c) limão 'Volkameriano'. Barra = $10 \mu \mathrm{M}$. 

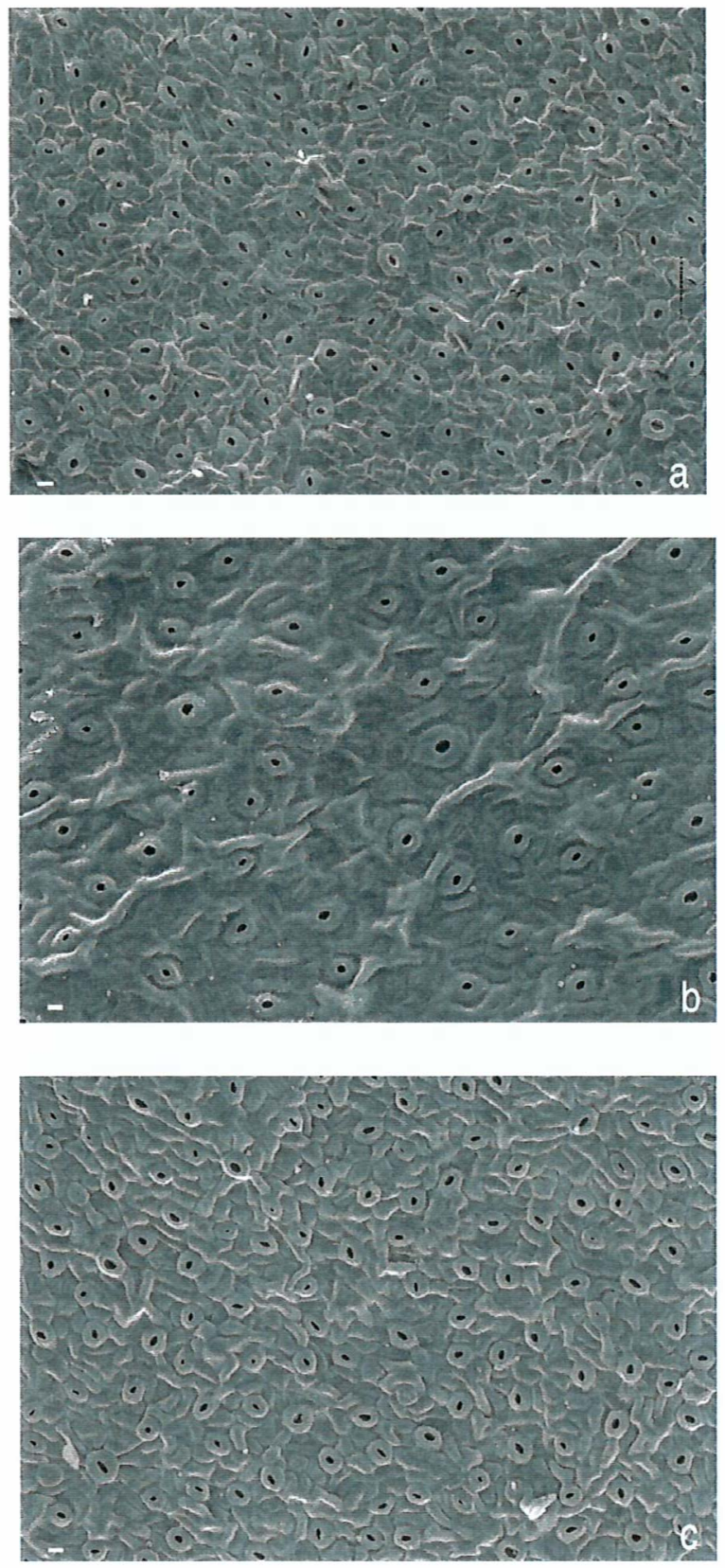

Figura 7 Epidermes foliares abaxiais de plantas diplóides e do respectivo produto de fusão de protoplastos. a) laranja 'Ruby Blood', b) laranja 'Ruby Blood' + limão 'Volkameriano', c) limão 'Volkameriano'. Barra $=10 \mu \mathrm{M}$. 


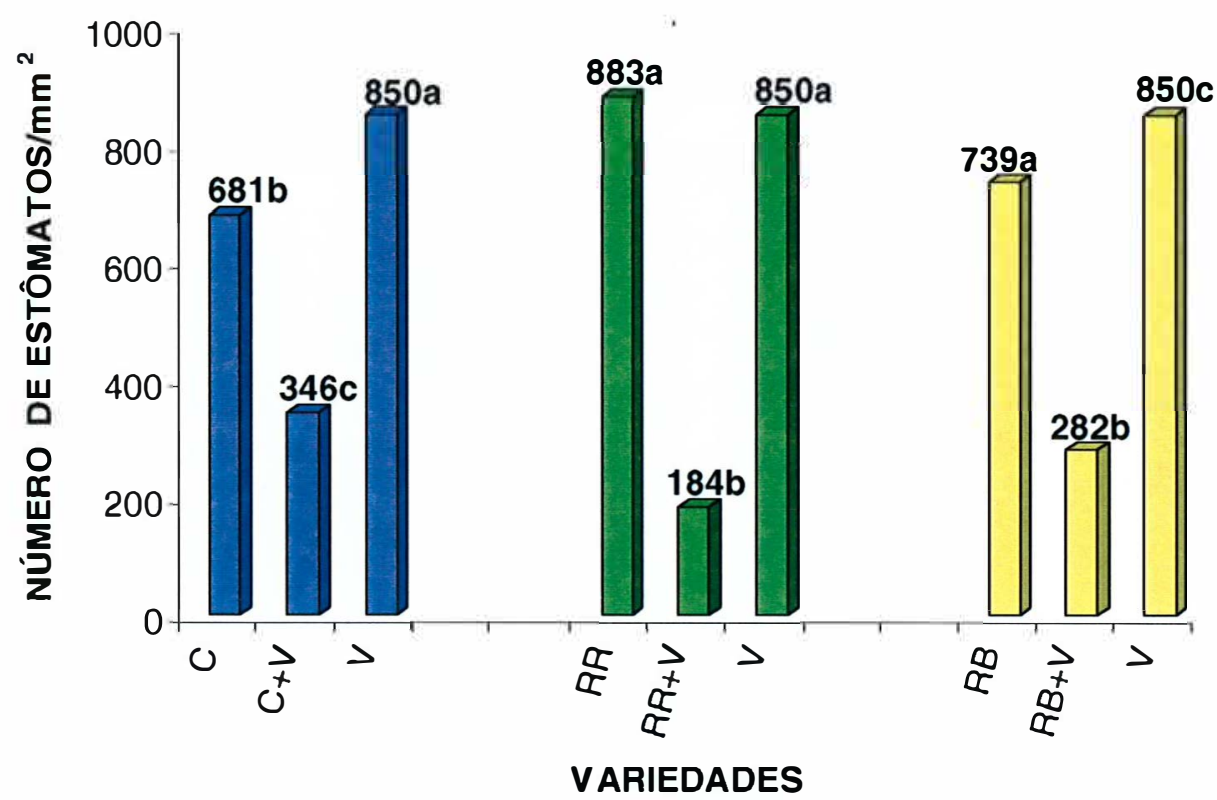

Figura 8. Número médio de estômatos $/ \mathrm{mm}^{2}$ dos parentais diplóides e respectivos produtos de fusão. C (tangerina 'Cleópatra'), C + V (tangerina 'Cleópatra' + limão 'Volkameriano'), V (limão 'Volkameriano'), RR (laranja 'Valência Rohde Red'), RR + V (laranja 'Valência Rohde Red' + limão 'Volkameriano'), RB (Iaranja 'Ruby Blood'), RB + V (Iaranja 'Ruby Blood' + limão 'Volkameriano'). 


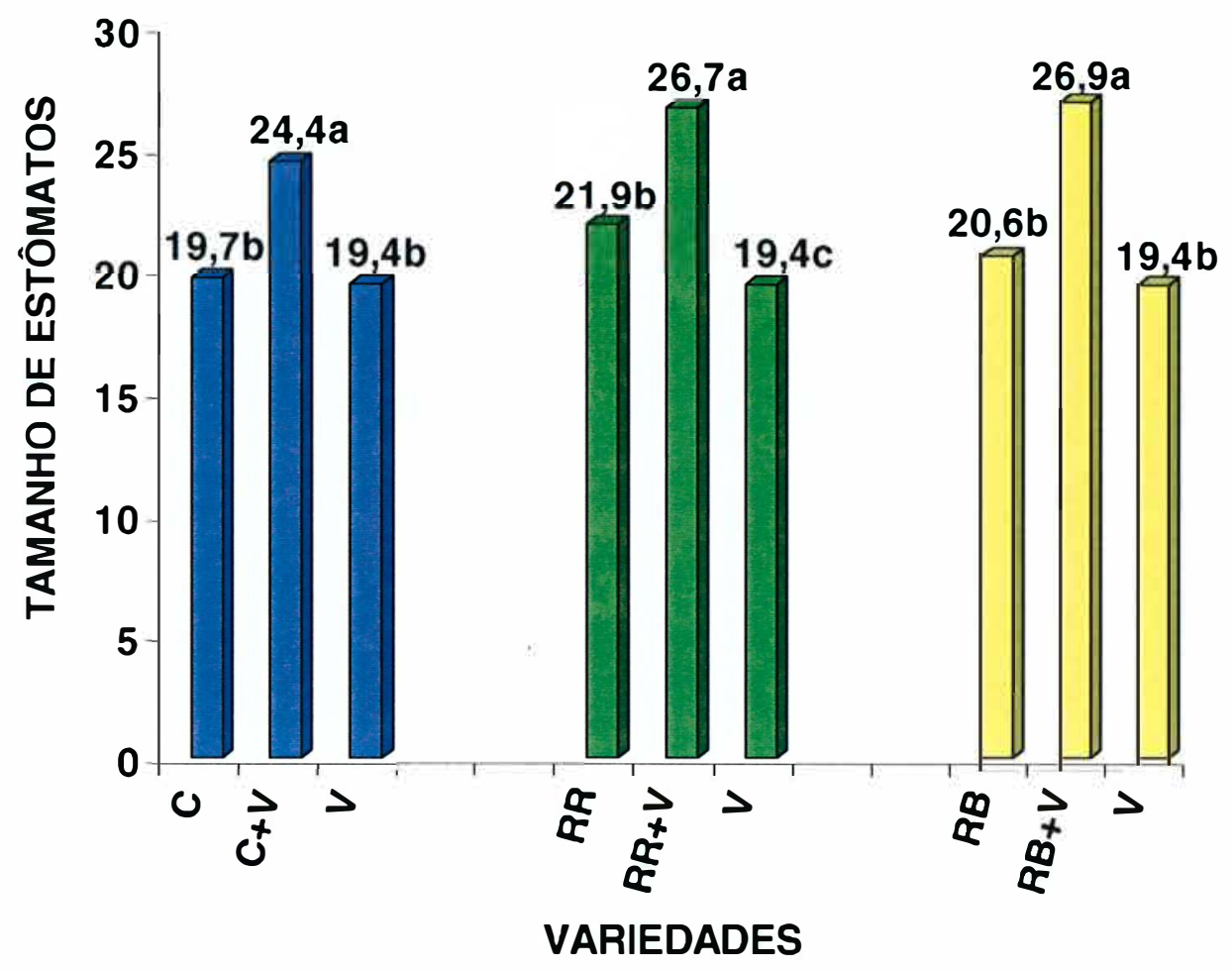

Figura 9. Tamanho médio de estômatos $(\mu \mathrm{m})$ dos parentais diplóides e respectivos produtos de fusão. C (tangerina 'Cleópatra'), $C+V$ (tangerina 'Cleópatra' + limão 'Volkameriano'), V (limão 'Volkameriano'), RR (Iaranja 'Valência Rohde Red'), RR + V (laranja 'Valência Rohde Red' + limão 'Volkameriano'), RB (laranja 'Ruby Blood'), RB + V (laranja 'Ruby Blood' + limão 'Volkameriano'). 
custo, pois apenas individuos poliplóides serão mantidos em condição de cultivo.

\subsubsection{Análise de DNA genômico, por marcadores tipo RAPD, citologia e morfologia foliar dos produtos de fusão}

A técnica de RAPD consiste em uma poderosa ferramenta para identificação de híbridos somáticos. Esta é fundamentada na reação de amplificação de fragmentos de DNA, a partir de "primers" com seqüência arbitrária. Assim, o polimorfismo, é detectado simplesmente através de fragmentos de DNA que foram amplificados em alguns indivíduos e não em outros. De acordo com Cruz et al. (1998), este polimorfismo decorre de diferenças ao nivel do DNA, as quais podem incluir trocas, deleções ou inserções de nucleotídeos nos sítios de anelamento dos "primers" ou entre eles.

Para análise dos híbridos somáticos, uma seleção de "primers" é necessária na identificação de marcadores polimórficos entre os dois parentais envolvidos no processo de fusão. A partir desta análise, novas reações PCR são realizadas envolvendo os parentais e prováveis híbridos.

$\mathrm{Na}$ análise do polimorfismo envolvendo os parentais tangerina 'Cleópatra' e limão 'Volkameriano', foram testados 40 "primers", 20 do Kit $A A$ e 20 do Kit $A B$. Destes apenas 15 "primers" apresentaram polimorfismo (OPAA2; OPAA3; OPAA8; OPAA13; OPAA14; OPAA16; OPAA17; OPAA20; OPAB6; OPAB8; OPAB10; OPAB15; OPAB17; OPAB19 e OPAB20), 22 revelaram bandas monomórficas e 3 não apresentaram amplificações satisfatórias (OPAA1, OPAB5 e OPAA18). Dentre os 15 "primers" que apresentaram polimorfismo, o OPAA8 e OPAA16 
evidenciaram a contribuição de DNA da tangerina 'Cleópatra', o OPAA3 do limão 'Volkameriano' e OPAA2, OPAA13 e OPAA17 expressaram seqüências de DNA de ambos os parentais (Figura 10a).

Os "primers" OPAA14, OPAA20, OPAB6, OPAB8, OPAB10, OPAB15, OPAB17, OPAB19, OPAB20, não apresentaram padrões polimórficos quando analisados conjuntamente com o produto de fusão. Possivelmente este comportamento deve-se a algum rearranjo do material genético durante o processo de fusão.

As análises mitóticas de células somáticas de ponta de raiz confirmaram que se tratam de um tetraplóide, $2 n=4 x=36$ cromossomos. Nota-se que os cromossomos de citros são semelhantes entre si e de tamanho bastante reduzido, mesmo em aumentos de 1250X (Figura, 10b). Estas observações confirmaram a natureza poliplóide dos produtos de fusão, contudo não evidenciam a hibridação somática.

A avaliação morfológica foliar das plantas aclimatizadas revelou que estas apresentaram características intermediárias à dos parentais, com folhas mais espessas, arredondadas, asa do pecíolo mais larga e de intensa coloração. (Figura 10c). Este fato pode ser explicado devido os alotetraplóides, possuírem maior número de cromossomos $\mathrm{e}$, conseqüentemente, maior volume nuclear e celular (Ramalho et al., 1990). Segundo Miranda et al. (1997) estas características são esperadas em plantas poliplóides.

Comportamento semelhante ocorreu nas plantas provenientes das fusões envolvendo laranjas doces e limão 'Volkameriano'. Dos 40 "primers" testados 10 apresentaram polimorfismo para os parentais laranja 'Valência Rohde Red' (OPAA2; OPAA4; OPAA7; OPAA8; OPAA11; OPAA14; OPAA16; OPAA17; OPAB6; OPAB8 e OPAB10) e 13 para laranja 'Ruby Blood' (OPAA2; OPAA3; OPAA7; OPAA8; OPAA13; OPAA14OPAA16; OPAA17; OPAA18; OPAB13; OPAB17; OPAB19 e OPAB20). No restante dos "primers", o padrão de amplificação foi 
Figura 10. Caracterização dos produtos de fusão de protoplastos das variedades tangerina 'Cleópatra' + limão 'Volkameriano'. a) Fragmentos RAPD. Colunas 1 a $3=$ "primer" OPAA2; colunas 4 a $6=$ "primer" OPAA3; colunas 7 a $9=$ "primer" OPAA8; colunas 10 a 12 = "primer" OPAA13; colunas 13 a $15=$ "primers" OPAA16, colunas 16 a $18=$ "primers" OPAA17. Colunas $1,4,7,10,13$ e $16=$ tangerina 'Cleópatra'; colunas $2,5,8,11,14$ e 17 = produto de fusão de protoplastos; colunas $3,6,12,15$ e $18=$ limão 'Volkameriano'. $\mathrm{P}=$ leadder $1 \mathrm{~Kb}$. b) Célula da planta obtida da fusão de protoplastos contendo 36 cromossomos. Barra $=10 \mu \mathrm{m}$. c) Morfologia foliar de tangerina 'Cleópatra' (esquerda), tangerina 'Cleópatra' + limão 'Volkameriano' (centro) e Imão 'Volkameriano' (direita). 

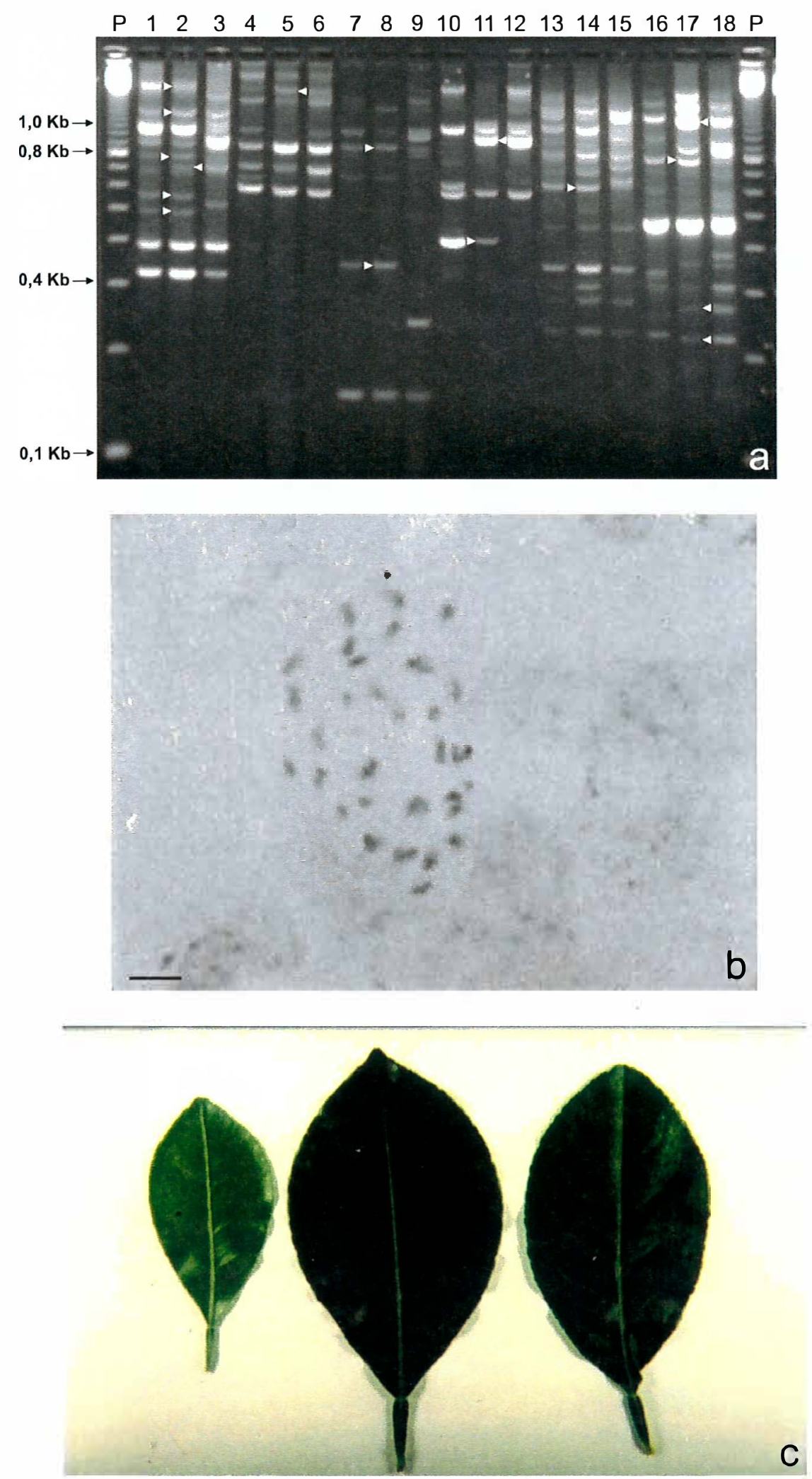
semelhante ou resultava num grande número de fragmentos de pouca intensidade.

Quanto à planta de laranja 'Valência Rohde Red' + limão 'Volkameriano', dos 10 "primers" que apresentaram polimorfismo, o OPAA4, OPAA8 e OPAA17, demonstraram a contribuição de ambos parentais e os "primers" OPAA7 e OPAA8 a contribuição da laranja 'Valência Rohde Red'. (Figura 11a). Apesar dos demais "primers" apresentaram polimorfismo quando avaliados conjuntamente com 0 produto de fusão, os padrões de amplificações revelaram bandas muito fracas. A Figura 11b mostra uma célula com 36 cromossomos, tetraplóide. A análise da morfologia foliar revelou que na combinação de fusão, as folhas são mais arredondadas e com coloração mais intensa comparado aos parentais (Figura 11c).

Para a combinação da laranja 'Ruby Blood' + limão 'Volkameriano' dos 13 "primers" que revelaram polimorfismo, o OPAA2 e OPAA7 evidenciaram a contribuição da laranja, enquanto os fragmentos de DNA amplificados com os "primers" OPAA17, OPAA18 e OPAB13 revelaram a presença do DNA genômico do limão 'Volkameriano', o "primer" OPAA8 demonstrou a contribuição de ambos os parentais (Figura 12a). Quanto aos demais "primers", não foram passíveis de reprodução quando analisadas conjuntamente com o produto de fusão.

De acordo com a análise citológica da planta obtida de fusão de protoplastos, confirmou que se trata de um tetraplóide. (Figura 12b). Quanto a análise morfológica foliar revelou que a folha da planta de fusão de protoplastos apresenta limbo foliar mais largo comparado aos parentais. (Figura 12c),

De um modo geral, o polimorfismo observado entre as combinações interespecíficas foi considerado muito baixo. Uma provável justificativa para esta alta similaridade seria o fato de que a variabilidade 
Figura 11. Caracterização dos produtos de fusão de protoplastos das variedades laranja 'Valência Rohde Red' + limão 'Volkameriano'. a) Fragmentos RAPD. Colunas 1 a $3=$ "primer" OPAA4; colunas 4 a $6=$ "primer" OPAA7; colunas 7 a 9 = "primer" OPAA8; colunas 10 a 12 = "primer" OPAA11; colunas 13 a $15=$ "primers" OPAA17. Colunas $1,4,7,10 \mathrm{e}$ 13 = laranja 'Valência Rohde Red'; colunas $2,5,8,11$ e 14 $=$ produto de fusão de protoplastos; colunas $3,6,12$ e $15=$ limão 'Volkameriano'. $\mathrm{P}=$ leadder $1 \mathrm{~Kb}$. b) Célula da planta obtida da fusão de protoplastos contendo 36 cromossomos. Barra $=10 \mu \mathrm{m}$. c) Morfologia foliar de laranja 'Valência Rohde Red' (esquerda), Iaranja 'Valência Rohde Red' + limão 'Volkameriano' (centro) e Imão 'Volkameriano' (direita). 

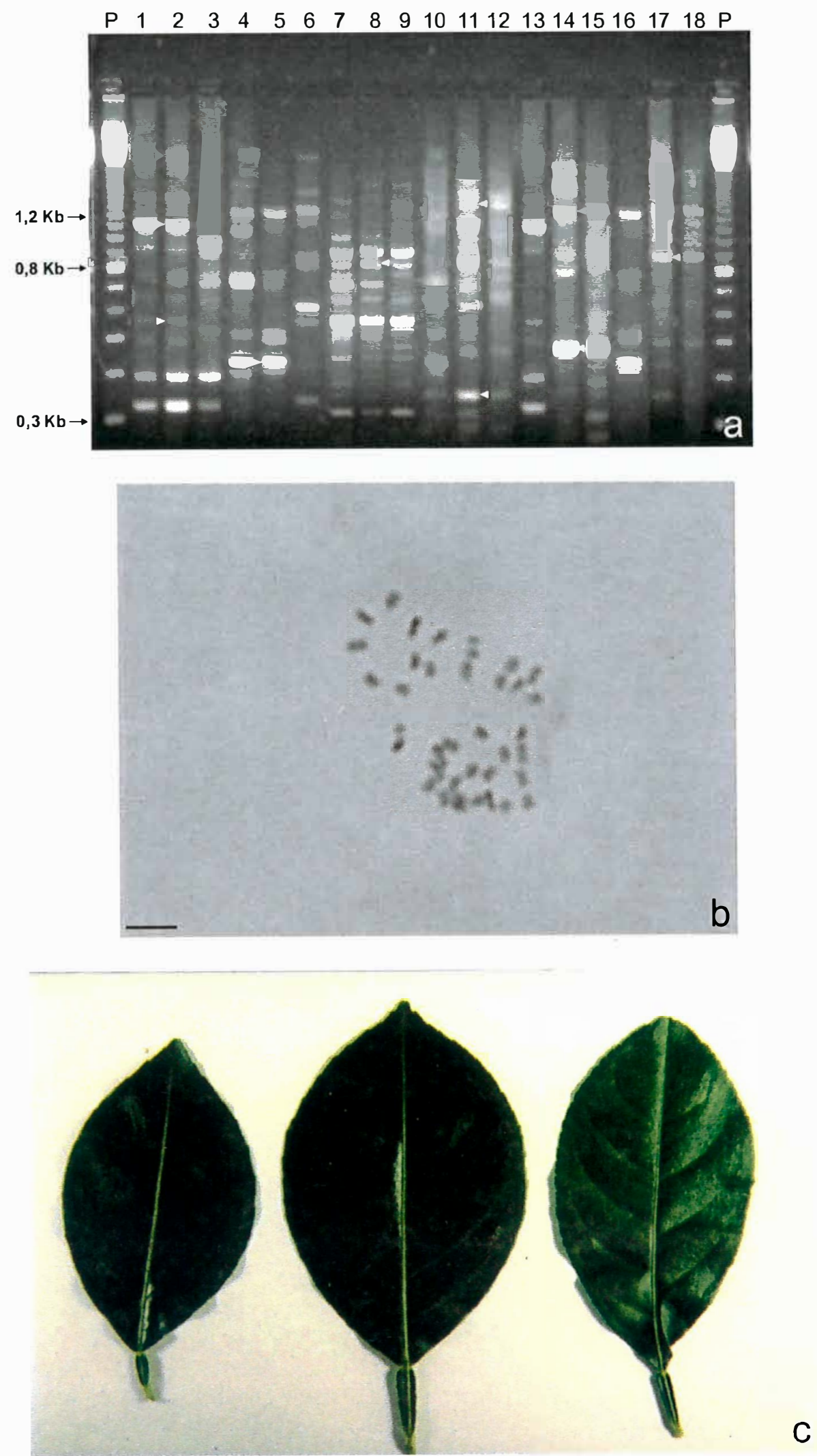
Figura 12. Caracterização dos produtos de fusão de protoplastos das variedades Iaranja 'Ruby Bood' + limão 'Volkameriano'. a) Fragmentos RAPD. Colunas 1 a $3=$ "primer" OPAA2; colunas 4 a $6=$ "primer" OPAA7; colunas 7 a $9=$ "primer" OPAA8; colunas 10 a $12=$ "primer" OPAA17; colunas 13 a $15=$ "primers" OPAA18, colunas 16 a $18=$ "primers" OPAB13. Colunas $1,4,7,10,13$ e 16 = laranja 'Ruby Bood'; colunas 2, 5, 8, 11, 14 e 17 = produto de fusão de protoplastos; colunas $3,6,12,15$ e $18=$ limão 'Volkameriano'. $\mathrm{P}=$ leadder $1 \mathrm{~Kb}$. b) Célula da planta obtida da fusão de protoplastos contendo 36 cromossomos. Barra $=10 \mu \mathrm{m}$. c) Morfologia foliar de laranja 'Ruby Bood' (esquerda), laranja 'Ruby Bood' + limão 'Volkameriano' (centro) e Imão 'Volkameriano' (direita). 

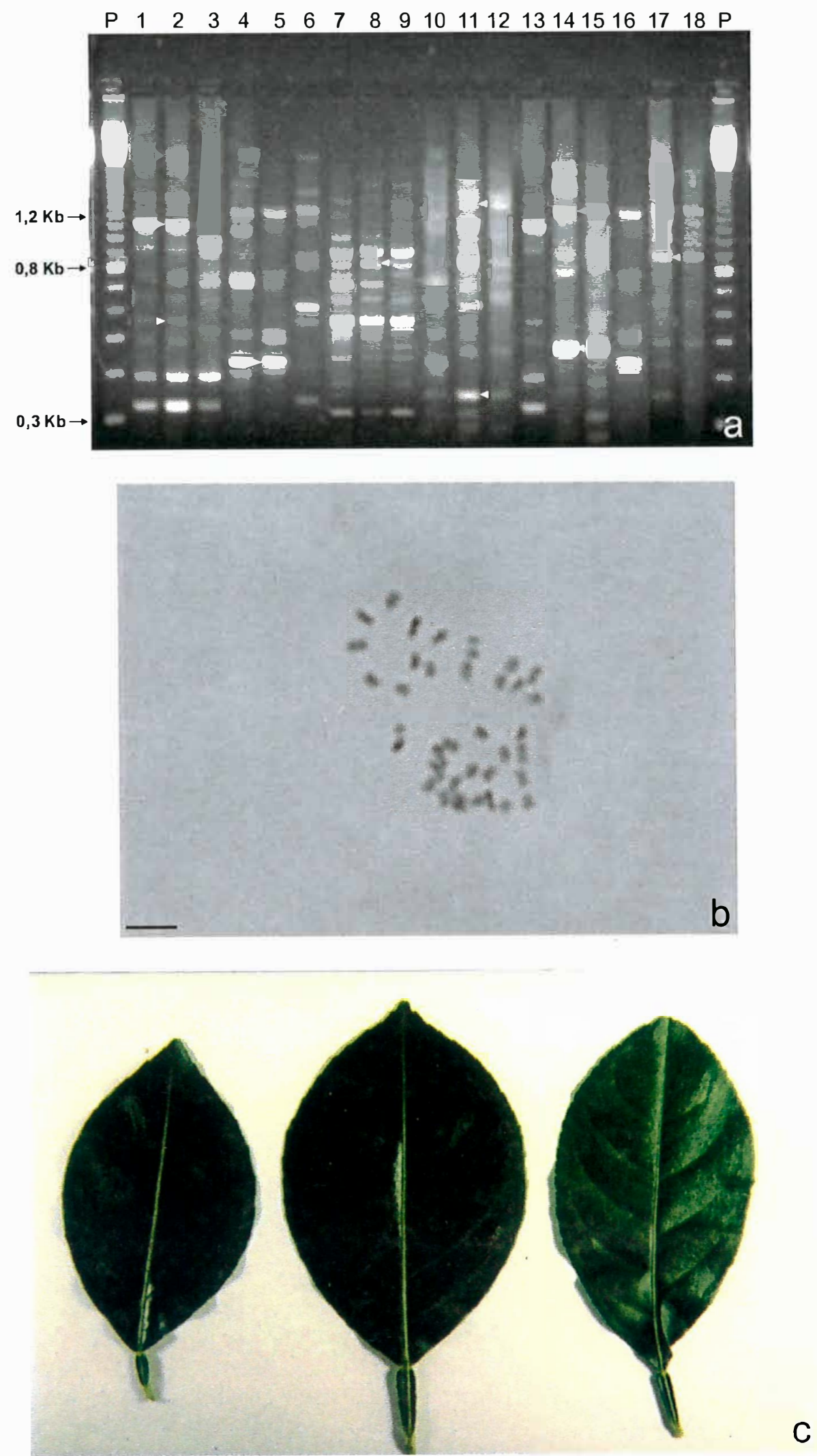
entre estes genótipos seja originária de mutações somáticas de gemas (Domingues et al., 1995). Assim, o polimorfismo entre estes individuos estaria restrito a porções reduzidas do DNA, dificeis de serem identificadas. Segundo Figueiredo (1991), a base genética da citricultura comercial é estreita, apesar da alta diversidade genética existente em citros.

Relações mais estreitas foram verificadas ao analisar os parentais limão 'Cravo' e tangerina 'Sunki'. Os Kits $A A$ e $A B$ revelaram monomorfismo para a maioria das regiões amplificadas e/ou não apresentaram padrões de amplificações. Apenas 6 "primers" do Kit, F revelaram polimorfismo. Destes, os "primers" OPF4, OPF13 e OPF19 indicaram a presença de DNA genômico de limão "Cravo e os "primers"; OPF1, OPF8 e OPF14 a contribuição da tangerina 'Sunki' (Figura 13a). A determinação do número de cromossomos confirmou a natureza tetraplóide das plantas (Figura 13b). De acordo com a análise morfológica dos parentais e da planta obtida de fusão de protoplastos (Figura 13c), observou-se que as folhas provenientes do experimento de fusão são mais espessas, arredondadas, com peciolo alado mais largo comparado aos parentais.

No caso da laranja 'Valência' cv. 63 + Fortunella obovata, como se trata de gêneros relacionados, e conseqüentemente uma maior divergência genética comparado as demais variedades estudadas, realizou-se a seleção de 10 "primers", 5 do Kit AA (OPAA14-18) e 5 do Kit $A B$ (OPAB5 -8 e OPAB14-19). Dos 10 "primers" testados, 7 (OPAA14, OPAA15, OPAA17, OPAB8, OPAB16, OPAB18, OPAB19), revelaram bandas polimórficas, um dos "primes" revelou monomorfismo para todas as regiões amplificadas (OPAA15), enquanto 2 "primers" (OPAB 5-6) não 
Figura 13. Caracterização dos produtos de fusão de protoplastos das variedades limão 'Cravo' + tangerina 'Sunki'. a) Fragmentos RAPD. Colunas 1 a $3=$ "primer" OPF1; colunas 4 a $6=$ "primer" OPF4; colunas 7 a $9=$ "primer" OPF8; colunas 10 a 12 = "primer" OPF13; colunas 13 a $15=$ "primers" OPF14, colunas 16 a $18=$ "primers" OPF19. Colunas $1,4,7,10,13 \mathrm{e}$ 16 = limão 'Cravo'; colunas 2, 5, 8, 11,14 e $17=$ produto de fusão de protoplastos; colunas $3,6,12,15$ e $18=$ tangerina 'Sunki'. $\mathrm{P}=$ leadder $1 \mathrm{~Kb}$. b) Célula da planta obtida da fusão de protoplastos contendo 36 cromossomos. Barra $=10 \mu \mathrm{m}$. C) Morfologia foliar de limão 'Cravo' (esquerda), limão 'Cravo' + tangerina 'Sunki' (centro) e tangerina 'Sunki' (direita). 

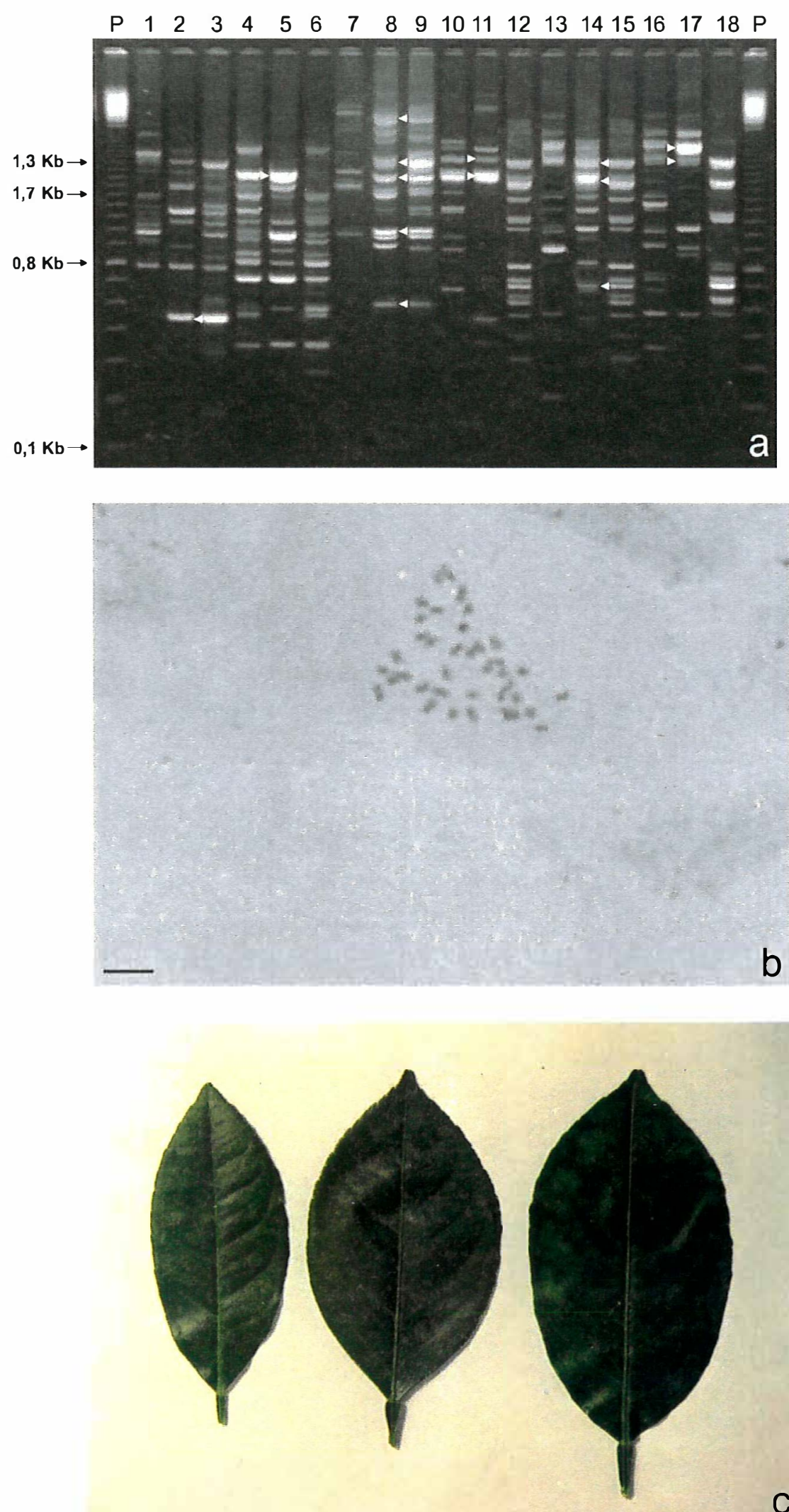

C 
apresentaram padrões de amplificações satisfatório. O primeiro relato de seleção de "primers" para combinações intergenéricas foi mencionada por Mourão Filho (1995), ao analisar os híbridos somáticos resultantes das combinações laranja 'Succari' + Feronia limonia, Atalantia ceylanica e Severinia buxifolia.

O padrão de fragmentos resultantes da amplificação do DNA referente ao híbrido da combinação de laranja 'Valência' cv. 63 + Fortunella obovata, revelou que os fragmentos amplificados com os "primers" OPAB8, OPAA14, OPAB16, OPAA17 e OPAB16, caracterizam a contribuição de ambos parentais, enquanto o "primer" e OPAB18 revelou a presença do material genômico da laranja 'Valência' cv. 63 (Figura 14a). A Figura 14b revelou a natureza tetraplóide das plantas, mostrando célula com 36 cromossomos. De acordo com análise morfológica dos parentais e plantas proveniente dos produtos de fusão de protoplastos (Figura 14c), observou-se que estas apresentaram folhas mais arredondas e de pecíolo alado maior quando comparado aos parentais.

Com base nestes resultados, pôde-se confirmar a obtenção de 5 híbridos somáticos. As combinações de hibridações somáticas entre tangerina 'Cleopátra' + limão 'Volkameriano'; laranja 'Valência Rohde Rede' e 'Ruby Blood' + limão 'Volkameriano'; limão 'Cravo' + tangerina 'Sunki' e laranja 'Valência' cv. 158 + Fortunella obovata, podem produzir porta-enxerto vigorosos com aceitáveis características horticulturais tais como, tolerância ao declínio, nas combinações envolvendo tangerina e laranjas com limões, precocidade de produção e tolerância ao frio, combinação de laranja com Fortunella obovata, além de apresentarem potencial para controlar o tamanho das árvores. 
Figura 14. Caracterização dos produtos de fusão de protoplastos das variedades Iaranja 'Valência' cv. 58 + Fortunela obovata. a) Fragmentos RAPD. Colunas 1 a $3=$ "primer" OPAB8; colunas 4 a 6 = "primer" OPAA14; colunas 7 a $9=$ "primer" OPAA16; colunas 10 a 12 = "primer" OPAA17; colunas 13 a 15 = "primers" OPAB16, colunas 16 a 18 = "primers" OPAB16. Colunas $1,4,7,10,13$ e 16 = Iaranja 'Valência' cv. 58 ; colunas $2,5,8,11,14$ e $17=$ produto de fusão de protoplastos; colunas $3,6,12,15$ e $18=$ Fortunela obovata. $P=$ leadder $1 \mathrm{~Kb}$. b) Célula da planta obtida da fusão de protoplastos contendo 36 cromossomos. Barra $=10 \mu \mathrm{m} . \mathrm{c}$ ) Morfologia foliar de laranja 'Valência' cv. 58 (esquerda), 'Valência' cv. 58 + Fortunela obovata (centro) e Fortunela obovata (direita). 

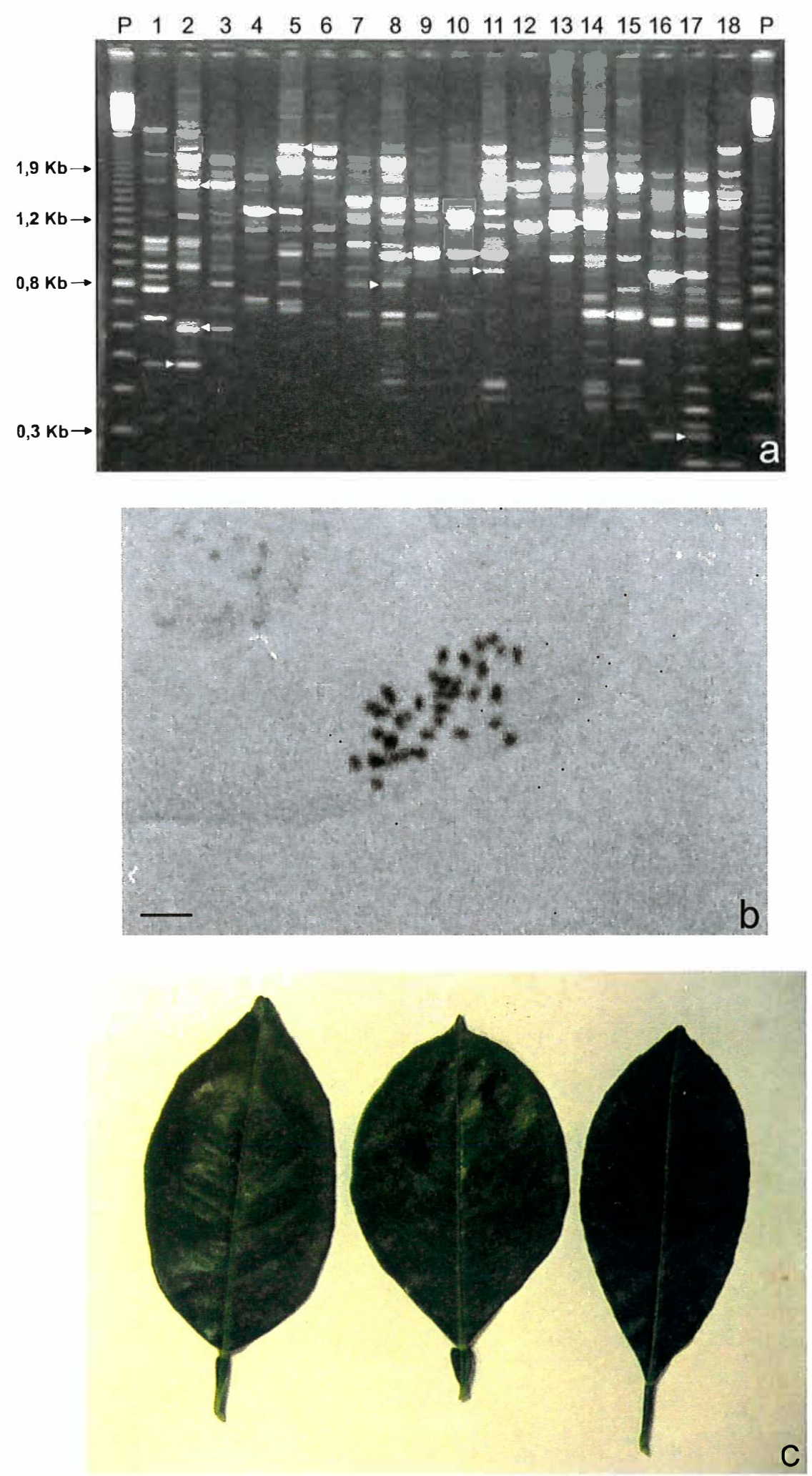


\section{CONCLUSÕES}

Com base nos resultados obtidos neste trabalho, pode-se concluir que:

1. O rendimento de protoplastos é influenciando pela composição da solução enzimática e pelas variedades;

2. A eficiência final de plaqueamento variou em função da densidade de cultivo dos protoplastos e da variedade estudada;

3. As melhores taxas de divisão celular e, consequentemente formação de colônias ocorreram nas densidades de plaqueamento de $10^{5}$ e $2 \times 10^{5}$ protoplastos. $\mathrm{mL}^{-1}$;

4. O desenvolvimento de calos vigorosos limita o desenvolvimento de embriões;

5. Plantas tetraplóides revelaram maior número e tamanho médio de estômatos, quando comparadas com os parentais diplóides; 
6. Os híbridos somáticos de tangerina 'Cleópatra' + limão 'Volkameriano', laranjas doces + limão 'Volkameriano' e limão 'Cravo'+ tangerina 'Sunki', possivelmente, devem apresentar características complementares aos dos parentais, podendo ser incluídos para avaliação em programas de melhoramento referente à porta-enxerto;

7. O híbrido de laranja 'Valência' cv. 63 + Fortunella obovata, Tanaka, possivelmente pode ser incorporado em programas de melhoramento de copa e proporcionar a produção de frutos sem sementes.

8. A histodiferenciação não ocorreu de maneira completa nos produtos de fusão envolvendo laranjas doces e tangerinas. 


\section{REEFRÊNCIAS BIBLIOGRÁFICAS}

ALLARD, R.W. Princípios de melhoramento genético de plantas. Rio de Janeiro: Edgard Bluecher, 1971, 38p.

AMARO, A.A.; ARAÚJO, C.M.; PORTO, O.M.; DORNELLES, C.M.M.; CUNHA SOBRINHO, A.P. da C.; PASSOS, O.S. Panorama da citricultura brasileira. In: RODRIGUEZ, Z.O; VIÉGAS, F.; POMPEU JUNIOR, J.; AMARO, A.S. (Ed.) Citricultura brasileira. Campinas: Fundação Cargil, 1991. v.1, p.22-59.

AMMIRATO, P.V. Induction, maintenance and manipulation of development in embryogenic cell suspension cultures. In: VASIL, I.K. Cell culture and somatic cell genetics of plants. Orlando: Academic Press, 1984. v.1, p.139-151.

AMORIM, E.P.R. Controle biológico de Phytophthora parasitica Dastur e Phytophthora citrophthora (Smith \& Smith) Leonian em plântulas de citros. Botucatu, 1997. 113p. Tese (Doutorado) - Faculdade de Ciências Agrárias, Universidade Estadual Paulista "Júlio de Mesquita Filho". 
ASKER, S. Progress in apomixes research. Hereditas, v.91, p.231-240, 1979.

AVENIDO, R.A.; ZAMOR, A.B.; PATENA, L.F.; BARBA, R.C. Callus induction and plant regeneration in calamansi $x$ Citrofortunella mitis $\mathrm{J}$. Ingram and H.E. Moore). Philippine Agriculturist, v.74, n.2, p.245252, 1991.

BALLVE, R.M.L.; MEDINA-FILHO, H.P.; BORDIGNON, R. Identification of reciprocal hybrids in citrus by the broadness of the leaf petiole wing. Revista Brasileira de Genética, v.20, p.697-703, 1997.

BARBOSA, L.V. Citologia de híbridos somáticos de Passiflora spp. Obtidos por fusão de protoplastos. Piracicaba, 1998. 94p. Tese (Doutorado) - Escola Superior de Agricultura "Luiz de Queiroz", Universidade de São Paulo.

BARRETT, H.C.; RHODES, A.M. A numerical taxonomic study of affinity relationships in cultivated Citrus and its close relatives. Systematic Botany, v.1, p.105-136, 1976.

BENEDITO, V.A. Hibridação somática entre tangerina 'Cleópatra'e laranja 'Azeda' por fusão de protoplastos. Piracicaba, 1999. 62p. Dissertação (Mestrado) - Escola Superior de Agricultura "Luiz de Queiroz", Universidade de São Paulo.

BENEDITO, V.A.; MOURÃO FILHO, F.A.A.; MENDES, B.M.J. Calogênese, embriogênese somática $e$ isolamento de protoplastos em variedades de laranja doce. Scientia Agricola, v.57, p.33-38, 2000. 
BENGOCHEA, T.; DODDS, J.H. A plant protoplast: a biotechnological tool for plant improvement. London: Chapman \& Hall, 1986. 90p.

BEN-HAYYIN, G.; NEUMAN, H. Stimulatory effect of glycerol. Zeitschrift fluer Pflanzenphysiologie, v.110, p.331-337, 1983.

BHAMBOTA, J.R.; KANWAR; J.S. Salinity tolerance of some rootstocks and scions of citrus species. In: INTERNATIONAL CITRUS SYMPOSIUM, 1., Riverside, 1969. Proceedings. Riverside: University of California, 1969. p.1833-1836.

BINDING, G.; BUNNING, D.; GORSCHEN, E.; JORGENSEN, J.; KOLLMANN, R.; KRUMBIEGEL-SCHROEREN, G.; LING, H.Q.; MONZER, J.; MORDHORST, G.; RUDNICK, J.; SAUER, A.; WITT, D.; ZUBA, M. Uniparental, fusant and chimeric plants regenerated from protoplasts after steak plating in agarose gels. Plant Cell, Tissue and Organ Culture, v.12, p.133-137, 1988.

BITTERS, W.P.; MURASHIGE, T.; RANGAN, T.S.; NAVER, E. Investigations on established virus-free citrus plants trough tissue culture. California Citrus Nurserymen's Society, v.9, p.27-30, 1970.

BORDGNOM, R.; MEDINA FILHO, H.P.; BALUÉ, R.M.L. Melhoramento genético de citros no Instituto Agronômico. Laranja, v.11, p.67-176, 1990.

BORGES, F. Tamano y densidad de estomas em clones cultivados y espécies selvagens de Musa. Agronomical Tropical, v.21, p.139-143, 1971. 
BUSQUET, R.N.B.; DONADIO, L.C.; MARTINEZ, J.A.; MALAVOLTA JÚNIOR, V.A. Avaliação de resistência ao cancro citrico de alguns híbridos de citros. In: CONGRESSO BRASILEIRO DE FRUTICULTURA, 3., Florianópolis, 1975. Anais. Florianópolis, 1975 v.1, p.301-319.

BUTTON, J. The effects of some carbohydrates on the growth and organization of Citrus ovular callus. Zeitschrift fluer Pflanzenphysiologie, v.88, p61-68, 1978.

BUTTON, J.; BORNMAN, C.H. Development of nucellar plants from unpollinated and unfertilized ovules of Washington Navel orange in vitro. Journal of South African Botany, v.37, p.127-134, 1971.

BUTTON, J.; KOCHBA, J. Tissue culture in citrus industry. In: REINERT, J.; BAJAJ, Y.P.S., (Ed) Applied and fundamental aspects of plant cell, tissue and organ culture. Berlin: Springer-Verlag, 1977. p.7092.

CABASSON, C.; ALVARD, D.; DAMBIER, D.; OllitRatRAULT, P.; TEISSON, C. Improvement of citrus somatic embryo development by temporary immersion. Plant Cell, Tissue and Organ Culture, v.50, p.33-37, 1997.

CAMERON, J.W.; FROST, H.B. Genetics, breeding and nucellar embryony. In: REUTHER, W.; BATCHELOR, L.D.; WEBBER, H.J. (Ed.) The citrus industry. Berkley: University of California, 1968. v.2, p.325-370. 
CARLBERG, I.; GLIMELINS, K.; ERIKSSON, T. Improved culture ability of potato protoplasts by use of activated charcoal. Plant Cell Reports, v.2, p.223-225, 1983.

CARNEIRO, V.T. de C.; CONROI, T.; BARROS, L.M.G.; MATSUMOTO, K. Protoplastos: cultura e aplicações. In: TORRES, A.C.; CALDAS, L.S.; BUSO, J.A. (Ed.) Cultura de tecidos e transformação genética de plantas. Brasília: EMBRAPA, SPI, CNPH, 1998. v.1, p.413-458.

CID, L.P.B. Suspensão celular. In: Torres, A.C.; CALDAS, L.S.; BUSO, J.A. (Ed.) Cultura de tecidos e transformação genética de plantas. Brasilia: EMBRAPA, SPI, CNPH, 1998. v.1,p.331-353.

COKING, E.C. A method for the isolation of plant protoplasts and vacuoles. Nature, v.187, p.927-929, 1960.

COLIJN-HOOYMANS, C.M.; BOUWER, R.; DONS, J.J.M. Plant regeneration from cucumber protoplasts. Plant Cell Tissue and Organ Culture, v.12, p.147-150, 1988.

CONSTABEL, F.; CUTLER, A.J. Protoplast fusion. In: FOWKE, L.C.; CONSTABEL, F. (Ed.) Plant protoplasts. Boca Raton: CRC Press, 1985. p.53-65.

CRISTOFANI, M. Adaptação de metodologias de cultura de tecidos visando o melhoramento através de indução de mutações em Citrus sinensis (L.) Osbeck cv. Pêra. Piracicaba, 1991. 185p. Dissertação (Mestrado) - Escola Superior de Agricultura "Luiz de Queiroz", Universidade de São Paulo. 
CRUZ, R.P.; MILACH, S.C.K. Análise de RAPD. In: MILACH, S.C.K. (Ed.) Marcadores moleculares em plantas. Porto Alegre: S.C.K. Milach, 1998. p.107-115.

CUTTER, E.G. Anatomia vegetal: Parte 1. Células e tecidos. São Paulo: Roca, 1986. cap.7, p.97-143: Epiderme.

D'ULTRA VAZ, F.B.; SANTOS, A.V.P. dos; MANDERS, G.; COCKING, E.C.; DAVEY, M.R.; POWER, J.B. Plant regeneration from leaf mesophyll protoplasts of the tropical woody plants, passion fruit (Passiflora edulis fv flavicarpa Degener.): the importance of the antibiotic cefatoxime in the culture medium. Plant Cell Reports, v.12, p.220-225, 1993.

DAVIES, F.; ALBRIGO, L. Citrus. Wallingford: CAB International, 1994. cap.2, p.12-51: Taxonomy, cultivars and breeding.

DAVIES, P.J. The role of hormones in plant development. In: HOPKINS, W.G. Introduction to plant physiology. London: University of Western Ontario, 1995. cap.15, p.285-310.

DEIDDA, D. Embrioni nucellari di clementine ottenuti in vitro. Rivista della Ortoflora-Frutticoltura Italiana, v.54, n.4, p.291-296, 1973.

DENG, X.X.; GROSSER, J.W.; GMITTER JUNIOR, F. Intergeneric somatic hybrid plants from protoplast fusion of Fortunella crassifolia cultivar 'Meiwa' with Citrus sinensis cultivar 'Valencia'. Scientia Horticulturae, v.49, p.55-62, 1992. 
DODDS, J.H.; ROBERTS, L.W. Experimental in plant tissue cultures. Cambridge: Cambridge University Press, 1985. 232p.

DOMINGUES, E.T.; TULMANN NETO, A.T.; TEÓFILO SOBRINHO, J. Importância das mutações somáticas no melhoramento das variedades de citros. Laranja, v.16, p.235-250, 1995.

DONADIO, L.C.; TEÓFILO SOBRINHO, J. Estudo comparativo de híbridos e mudas de laranjeira Baianinha. Científica, v.1, p.107-114, 1975.

DONADIO, L.C.; STUCHI, E.S. Selection of Satsuma hybrids. Proceedings of the International Society of Citriculture, v.1, p.7475, 1992.

DONADIO, L.C.; FIGUEIREDO, J.O.; PIO, R.M. Variedades cítricas. Jaboticabal: Fundação Cargill, 1995. 228p.

DONADIO, L.C.; RODRIGUEZ, O.; POMPEU JUNIOR, J.; TEÓFILO SOBRINHO, J. Número de sementes em frutos de plantas citricas obtidas de sementes irradiadas. In: CONGRESSO BRASILEIRO DE FRUTICULTURA, 2., Viçosa, 1973. Anais. Viçosa, 1973. p.297-303.

DORNELAS, M.C. Cultura e fusão de protoplastos de Passiflora spp. Piracicaba, 1995. 182p. Dissertação (Mestrado) - Escola Superior de Agricultura "Luiz de Queiroz", Universidade de São Paulo.

EEPSTEIN, E.; KOCHBA, J.; NEUMANN, H. Metabolism of indolacetic acid by embriogenic and non-embriogenic callus lines of 'Shamouti' orange (Citrus sinensis). Zeitsxhriftfuer Pflanzephysiologie, v.85, p.265-268, 1977. 
ERIKSON, T.R. Protoplast isolation and culture. In: FOWLE, L.C.; CONSTABEL, F. (Ed.) Plant protoplasts. Boca Raton: CRC Press, 1985. p.1-20.

ESAN, E.B. A detailed study of adventive embryogenesis in the rutaceae. Riverside, 1973. 233p. Thesis (Ph.D) - University of California.

EVANS, D.A. Protoplast fusion. In: EVANS, S.A.; SHARP, W.R.; AMMIRATO, P.V.; YAMADA, Y (Ed.) Handbook of plant cell culture. New York: McMillan Press, 1983. cap.7, p.291-32.

EVANS, D.A. Use of protoplast fusion for crop improvement. In: CROCOMO, O.J.; SHARP, W.R.; MELO, M. (Ed.) Biotecnologia para produção vegetal. Piracicaba: CEBITEC; FEALQ, 1991. p.391-429.

EVANS, D.A.; BRAVO, J.E. Protoplast isolation and culture. In: EVANS, D.A.; SHARP, W.R.; AMMIRATO, P.V.; YAMADA, Y. (Ed.) Handbook of plant cell culture. New York: McMillan Press, 1983. v.1, p.124176.

EVANS, D.A.; COCKING, E.C. Isolated plant protoplasts. In: STREET, H.E. (Ed.) Plant tissue and cell culture. Oxford: Blackwell Scientific, 1977. v.11, p.103-135. (Botanical Monographs).

EVANS, P.K.; WILSON, V.M. Plant somatic hybridization. In: COAKER, T.H. (Ed.) Advances in applied biology. Cambridge: Academic Press, 1984. cap.10, p.1-69.

FAO. FAOSTAT - Statistics database. http:llapps.fao.org. (15 agosto 2001). 
FERNANDO, J.A. Estudos Anatômicos da embriogênese somática in vitro em soja (Glycine Max (L.) Merrill). Piracicaba, 1999. 86p. Dissertação (Mestrado) - Escola Superior de Agricultura "Luiz de Queiroz", Universidade de São Paulo.

FERREEIRA, M.E.; GRATTAPAGLIA, D. Introdução ao uso de marcadores moleculares em análise genética. 2.ed. Brasilia: EMBRAPA, CENARGEN, 1995. 220p.

FIGUEIREDO, J.O. de. Variedades copa de valor comercial. In: RODRIGUEZ, O.; VIEGAS, F.; POMPEU JUNIOR, J.; AMARO, A.S. Citricultura brasileira. Campinas: Fundação Cargill, 1991. p.228264.

FNP CONSULTORIA E COMÉRCIO. Agrianual 2000. São Paulo, 2001.

FREARSON, E.M.; POWE, J.B.; COCKING, E.C. The isolation, culture and regeneration of Petúnia leaf protoplasts. Developmental Biology, v.33, p.130-137, 1973.

FUNDECITRUS. http://www. fundecitrus.com.br (05 março 2001).

FUNGARO, M.H.P.; VIEIRA, M.L.C. Protoplastos de plantas: isolamento e regeneração. Ciência e Cultura, v.41, n.12, p.1151-1159, 1989.

GALUN, E.; REVEH, D. In vitro culture of tobacco protoplasts: survival of haploid and diploid protoplasts exposed to $x$-ray radiation at different times after isolation. Radiation Botany, v.15, p.79-82, 1975. 
GINDY, E.F. Plant regeneration from sour orange and Rangpur lime undeveloped ovule cultures. Annals of Agricultural Science, v.28, n.4, p.2407-2417, 1990.

GLEDDIE, S.C. Protoplasts and transformation procedures. In: GAMBORG, O.L.; PHILLIPS, G.C. (Ed) Plant cell tissue and organ culture: fundamental methods. Berlin: Springer-Verlag, 1995. cap.14, p.167-180.

GMITTER JUNIOR, F.G.; MOORE, G.A. Plant regeneration from undeveloped ovules and embryogenic calli of Citrus: embryo production, germination, and plant survival. Plant Cell, Tissue and Organ Culture, v.6, p.139-147, 1986.

GMITTER JUNIOR, F.G.; GROSSER, J.W.; MOORE, G.A. Citrus. In: HAMMERSCHLAG, F.A.; LITZ, R.E. (Ed.) Biotechnology of perennial fruit crops. Cambridge: Cambridge University Press, 1992. cap,14, p.335-369.

GOLDMAN, M.H.S. Cultura de tecidos nucelares, isolamento e radiossensitividade de protoplastos de Citrus sinensis (L.) Osbeck cv Pêra. Piracicaba, 1988. 172p. Dissertação (Mestrado) - Escola Superior de Agricultura "Luiz de Queiroz", Universidade de São Paulo.

GROSSER, J.W.; CHANDLER, J.L. Aseptic isolation of leaf protoplasts from Citrus, Phcirus, Citrus $X$ Poncirus Hybrids and Severinia for use in somatic hybridization experiments. Scientia Horticulturae, v.31, p.253-257, 1987 
GROSSER, J.W.; GMITTER JUNIOR, F.G. Somatic hybridization of Citrus with wild relatives for germoplasm enhancement and cultivar development. HortScience, v.25, n.2, p.147-151, 1990a.

GROSSER, J.W.; GMITTER JUNIOR, F.G. Protoplast fusion and citrus improvement. Plant Breeding Reviews, v.8, p.339-374, $1990 \mathrm{~b}$.

GROSSER, J.W.; GMITTER JUNIOR, F.G.; CHANDLER, J.L. Intergeneric somatic hybrids plants of Citrus sinensis cv. 'Hamlin' and 'Poncirus trifoliata' cv. 'Frying Dragon'. Plant Cell Reports, v.7, p.5-8, 1988a

GROSSER, J.W.; GMITTER JUNIOR, F.G.; CHANDLER, J.L. Intergeneric somatic hybrid from sexually incompatible woody species: Citrus sinensis and Severina discha. Theoretical and Applied Genetics, v.75, p.397-401, 1988b.

GROSSER, J.W.; MOORE, G.A.; GMITTER JUNIOR, F.G. Interspecific somatic hybrid plants from fusions of 'Key' lime (Citrus aurantifolia) with 'Valência' sweet orange (Citrus sinensis) protoplasts. Scientia Horticulturae, v.39, p.23-29, 1989

GROSSER, J.W.; GMITTER JUNIOR, F.G.; CHANDLER, J.L. Somatic hybrid plants from sexually incompatible woody species: Citrus reticulata and Citropsis gilletiana. Plant Cell Reports, v.8, p.656$659,1990$.

GROSSER, J.M.; OLLITRAUT, P.; OLIVARER-FUSTER, O. Imvited reviw: Somati hybridization in Citrus: na effective tool to facilite variety improvement. In vitro Celular Developmental. Biology, v.36, p.434$449,2000$. 
GROSSER, J.W.; LOUZADA, E.S.; GMITTER JUNIOR, F.G.; CHANDLER, H.L. Somatic hybridization of complementary citrus rootstocks: five new hybrids. HortScience, v.29, n.7, p.812-813, 1994

GROSSER, J.W.; GMITTER JUNIOR, F.G.; CASTLE, W.S.; CHANDLER, J.L. Production and evaluation of citrus somatic hybrid rootstocks: progress report. Proceedings of the Florida State Horticultural Society, v.108, p.140-143, 1995

GROSSER, J.W.; GMITTER JUNIOR, F.G.; CASTLE, W.S.; CHANDLER, J.L. Somatic hybridization: a new approach to citrus rootstock improvement. Fruits, v.53, p.331-334, 1998a.

GROSSER, J.W.; GMITTER JUNIOR, F.G.; LOUZADA, E.S.; CHANDLER, J.L. Production of somatic hybrid and autotretaploid breeding parents for seedless citrus development. HortScience, v.27, n.10, p.1125$1127,1992 a$

GROSSER, J.W.; JIANG, J.; LOUZADA, E.S.; CHANDLER, J.L.; GMITTER JUNIOR, F.G. Somatic hybridization, an integral component of citrus cultivar improvement: II. Rootstock improvement. HortScience, v.33, n.6, p.1060-1061, 1998b

GROSSER, J.W.; GMITTER JUNIOR, F.G.; SESTO, F.; DENG, X.X.; CHADLIER, J.L. Six new hybrids somatics and their potential for cultivar improvement. Journal of the American Society for Horticultural Science, v.117, n.1, p.169-173, 1992b. 
GROSSER, J.W.; GMITTER JUNIOR, F.; TUSA, N.; REFORGIATO RECUPERO, G.; CUCINOTTA, P. Futher evidence of a cybridization requeriment for plant regeneration from citrus leaf protoplasts following somatic fusion. Planrt Cell Reports, v.15, p.672-676, 1996a

GROSSER, J.W.; JIANG, J.; MOURÃO FILHO, F.A.A.; LOUZADA, E.S.; CHANDLER, J.L.; GMITTER JUNIOR, F.G. Somatic hybridization, an integral component of citrus cultivar improvement: I. Scion improvement. HortScience, v.33, n.6, p.1057-1059, 1998c.

GROSSER, J.W.; MOURÃO FILHO, F.A.A.; GMITTER JUNIOR, F.G.; LOUZADA, E.S.; JIANG, J.; BAERGEN, K.; QUIROS, A.; CABASSON, C.; SCHELL, J.L.; CHANDLER, J.L. Allotetraploid hybrids between citrus and seven related genera produced \& by somatic hybridization. Theoretical and Applied Genetics, v.92, p.557-582, 1996b.

GUERRA, M.P.; TORRES, A.C.; TEIXEIRA, J.B. Embriogênese somática e sementes sintéticas. In: TORRES, C.T.; CALDAS, L.S.; BUSO, J.A. Cultura de tecidos e transformação genética de plantas. Brasília: Embrapa, 1998. v.2, p.533-568.

GUO, W.W.; DENG, X.X. Somatic hybrid plantlets regeneration between Citrus and its wild relative, Murraya paniculata via protoplast electrofusion. Plant Cell Reports, v.18, p.297-300, 1998.

HANSCHE, P.E. Response to selection. In: MOORE, J.N.; JANICK, J. (Ed.) Methods in fruit breeding. West Lafayette: Purdue University, 1983. p.154-171. 
HIDAKA, T. A 'Shuttle callus system' - application of tissue culture in citrus. Acta Horticulturae, n.392, p.39-48, 1995.

HIDAKA, T.; KAJIURA, I. Plantlet differentiation from callus protoplasts induced from Citrus embryo. Scientia Horticulturae, v.34, p.85-92, 1988.

HIDAKA, T.; OMURA, M. Control of embryogenesis in Citrus cell culture: regeneration from protoplasts and attempts to callus bank. Bulletin of the Fruit Tree Research Station. Série B, n.16, p.1-17, 1989

HIDAKA, T.; TAKAYANAGI, R.; SHINOZAKI, S.; FUJITA, K.; OMURA, M. Somatic hybrids obtained by electrofusion among citrus and its wild relatives. In: OONO, K. (Ed.) Plant tissue culture and gene manipulation for breeding and formation of phytochemicals. 1992. p.225-236

HOISINGTON, D.; KHAIRALLAH, M.; GONZÁLEZ-DE-LEÓN. Laboratory Protocols: CIMMYT Applied Molecular Genetics Laboratory. 2.ed. México: CIMMYT, 1994. 88p.

JIMÉINEZ, V.M. El cultivo de protoplastos en cítricos y su potencial para el mejoramiento genético. Agronomia Costarricense, v.20, n.2, p.187-204, 1996.

JUAREZ, J.; NAVARRO, L.; GUARDIOLA, J.L. Obtention de plants nucellaires de divers cultivars de clémentiniers au moyen della culture de nucelle in vitro. Fruits, v.31, p.751-762, 1976. 
KAO, K.N.; MICHAYLUK, M.R. A method for high-frequency intergeneric fusion of plant protoplasts. Planta, v.126, p.105-110, 1974.

KAO, K.; KELLER, W.A.; MILLER, R.A. Cell division in newly formed cells from protoplasts of soybean. Experimental Cell Research, v.62, p.338-340, 1970.

KOBAYASHI, S.; OHGAWARA, T. Production of somatic hybrid plants through protoplast fusion in citrus. Japan Agricultural Research Quarterly, v.22, n.3, p.181-188, 1988.

KOBAYASHI, S.; UCHIMIYA, H. Expression and integration of a foreign gene in orange (Citrus sinensis Osb.) protoplasts by direct DNA transfer. Japanese Journal of Genetics, v.64, p.91-97, 1989.

KOBAYASHI, S.; IKEDA, I.; NAKATANI, M. Induction of nucellar callus from orange (Citrus.sinensis Osb.) ovules and uniformity of regenerated plants. Bulletin of the Fruit Tree Research Station, n.5, p.43-54, 1984.

KOBAYASHI, S.; UCHIMYA, H.; IKEDA, I. Plant regeneration from 'Trovita' orange protoplasts. Japanese Journal of Breeding, V.33, p.119-122, 1983.

KOBAYASHI, S.; FUJIWARA, K.; OIYAMA, T.; OHGAWARA, T.; ISHII, S. A somatic hybrid plant obtained by protoplast fusion between navel orange (Citrus sinensis) and satsuma mandarin (Citrus. unshiu). Plant Cell, Tissue and Organ Culture, v.14, n.2, p.63-69, 1988b. 
KOBAYASHI, S.; OHGAWARA, T.; SAITO, W.; NAKAMURA, Y.; SHIMIZU, J. Fruit characteristics and pollen fertility of citrus somatic hybrids. Journal of the Japanese Society for Horticultural Science, v.64, n.2, p.283-289, 1995.

KOBAYASHI, S.; OIYAMA, I.; YOSHINAGA, K.; OHGAWARA, T.; ISHII, S. Fertility in an intergeneric somatic hybrid plant of Rutaceae. HortScience, v.26, p.207-210, 1991.

KOBAYASHI, S.; FUJIWARA, K.; OIYAMA, T.; OHGAWARA, T.; ISHII, S. Somatic hybridization between navel orange and 'Murcott' tangor. In: INTERNATIONAL CITRUS CONGRESS, 6., 1988a. Proceedings. 1988a. v.1, p.135-140.

KOCHBA, J.; SPIEGEL-ROY, P. Effect of culture media on embryoid formation from ovular callus of 'Shamouti' orange (Citrus sinensis). Journal of Plant Breeding, v.69, p.156-162, 1973.

KOCHBA, J.; SPIEGEL-ROY; P. The effects of auxins, cytokinins and inibitors on embryogenesis in habituated ovular callus of the 'Shamouti'orange (C. sinensis). Zeitschrift fur Pflanzenphysiolgie, v.81, p.283-288, 1977.

KOCHBA, J.; SPIEGEL-ROY, P.; SAFRAM, H. Adventives plants from ovules and nucelli in Citrus. Planta, v.106, p.237-245, 1972

KOCHBA, J.; SPIEGEL-ROY; P.; NEUMANN, H.; SAAD, S. Stimulation of embryogenesis in citrus ovular callus by $A B A$, ethephon, CCC and Alar and its suppression by GA3. Zeitschrift fur Pflanzenphysiolgie, v.89, p.427-432, 1978. 
KOCHBA, J.; SPIEGEL-ROY, P.; NEUMANN, H.; SAAD, S. Effect of carbohydrates on somatic embryogenesis in subculture nuclear callus of Citrus cultivars. Zeitschrift fluer Pflanzenphysiologie, v.105, p.359-368, 1982.

KOLLER, O.C. Citricultura: laranja, limão e tangerina. Porto Alegre: lligel, 1994. cap.5, p.49-62: Melhoramento e cultivares.

KUNITAKE, H.; MII, M. Somatic embryogenesis in Citrus species. In: BAJAJ, Y.P.S. (Ed.) Somatic embryogenesis and synthetic seed I. Berlin: Springer-Verlag, 1995. p.280-298. (Biotechnology in Agriculture and Forestry, 30).

LATADO, R.R. Hibridação somática entre limão Cravo (Citrus limonia Osbeck) e tangerina Cleópatra (Citrus reshni Hort.). Piracicaba, 1998. 146p. Tese (Doutorado) - Escola Superior de Agricultura "Luiz de Queiroz", Universidade de São Paulo.

LI, W. Avaliação do comportamento de variedades de copas e portaenxertos à clorose variegada dos citros. Jaboticabal, 1997. 103p. Tese (Doutorado) - Faculdade de Ciências Agrárias e Veterinárias, Universidade Estadual Paulista "Julio de Mesquita Filho".

LI, W.B. Estudo de resistência ou tolerância à clorose variegada dos citros. Jaboticabal, 1997. 107p. Tese (Doutorado) - Faculdade de Ciências Agrárias e Veterinárias, Universidade Estadual Paulista "Julio de Mesquita Filho". 
LING, J.; IWAMASA, M. Somatic hybridization between Citrus reticulata and Citropsis gabunensis through electrofusion. Plant Cell Reports, v. 13, p.493-497, 1994.

LING, J.-T.; NITO, N.; IWAMASA, M. Plant regeneration from protoplasts of Calamondin (Citrus mandurensis Lour.). Scientia Horticulturae, v.39, p.325-333, 1989.

LORZ, H.; LARKIN, P.J.; THOMSON, J.; SCOWCROFT, W.R. Improved protoplast culture in agarose media. Plant Cell Tissue and Organ Culture, v.2, p.217-226, 1983.

LOUZADA, E.S.; GROSSER, J.W.; GMITTER JUNIOR, F.G.; NIELSEN, B.; CHANDLER, J.L. Eight new somatic hybrid citrus rootstocks with potential for improved disease resistance. HortScience, v.27, n.9, p.1033-1036, 1992.

MEDEIROS, M.R.; VICHIATO, M.;DAVIDE, L.C.; PASQUAL, M. Estudo citogenético do 'Citravo' [Citrus limonia Osbeck cv. Cravo x Poncirus trifoliata (L.) Raf.] e seus genitores. Revista Brasileira de Fruticultura, v.22, p.20-23, 2000.

MENDES, B.M.J. Cultura de tecidos e hibridação somática em citros. Piracicaba, 1999. 60p. tese (Livre-Docência) - Centro de Energia Nuclear na Agricultura, Universidade de São Paulo.

MENDES-DA-GLÓRIA, F.J. Hibridação somática entre laranja 'Caipira' e limão 'Cravo' através de fusão de protoplastos. Piracicaba, 1998. 78p. Dissertação (Mestrado) - Escola Superior de Agricultura "Luiz de Queiroz", Universidade de São Paulo 
MENDES-DA-GLÓRIA, F.J.; MOURÃO FILHO, F.A.A.; CAMARGO, L.E.A.; MENDES, B.M.J. Caipira sweet orange + Rangpur lime: a somatic hybrid with potential for use as rootstock in the brasilian citrus industry. Genetics and Molecular Biology, n.3, p.661-665, 2000.

MENDES-DA-GLÓRIA, F.J.; MOURÃO FILHO, F.A.A.; DEMÉTRIO,C.B.; MENDES, B.M.J. Embryogenic calli induction from nucellar tissue of Citrus cultivars. Scientia Agricola, v.56, p.1111-1115, 1999.

MIRANDA, M.; MOTOMURA, T.; IKEDA, F.; OHGAWARA, T.; SAITO, W.; ENDO, T.; OMURA, M.; MORIGUCHI, T. Somatic hybrids obtained by fusion between Poncirus trifoliata $(2 \mathrm{x})$ and Fortunella hindsii (4x) protoplasts. Plant Cell Reports, v.16, p.401-405, 1997.

MITRA, G.C.; CHATUVERVEDI, H.C. Embryoids and complete plants from unpollinated ovaries and from ovules of in vitro grown emasculated flower buds of Citrus spp. Bulletin of Torrey Botanical Club, v.99, p.184-189, 1972.

MOORE, G.A. Factors affecting in vitro embryogenesis from undeveloped ovules of mature Citrus fruit. Journal of the American Society for Horticultural Science, v.110, p.66-70, 1985.

MOREIRA, S. Clones nucelares: caminho para uma nova citricultura. Revista de Agricultura, v.37,p.73-82, 1962 
MOREIRA, C.S.; PIO, R.M. Melhoramento de citros. In: RODRIGUEZ, Z. O.; VIÉGAS, F.; POMPEU JUNIOR, J.; AMARO, A.S. (Ed.) Citricultura brasileira. Campinas: Fundação Cargil, 1991. v.1, p.117-152.

MORIGUCHI, T.; HIDAKA, T.; OMURA, M.; MOTOMURA, T.; AKIHAMA, T. Genotype and parental combination influence efficiency of cybrid induction in Citrus by eletrofusion. HorScience, v.31, n.2, p.275-278, 1996.

MORIGUCHI, T.; MOTOMURA, T.; HIDAKA, T.; AKIHAMA, T.; OMURA, M. Analysis of mitocondrial genomes among Citrus plants produced by the interspecific somatic fusion of 'Seminole' tangelo with rough lemon. Plant Cell Reports, v.16, p.397-400, 1997.

MORIKAWA, H.; YAMADA, Y. Protoplast fusion. In: FOWLER, M.W.; WARREN, G.S.; MOO-YOUNG, M. (Ed.) Plant biotechnology: comprehensive biotechnology. Oxford: Pergamon Press, 1992. p.199-222.

MOTOMURA, T.; HIDAKA, T.; MORIGUCHI, T.; AKIHAMA, T.; OMURA, M. Intergeneric somatic hybrids between Citrus and Atalantia or Severina by eletrofusion, and recombination of mitochondrial genomes. Breeding Science, v.45,p.309-314, 1995.

MOURÃO FILHO, F.A.A. Protoplast fusion of citrus for rootstock and scion improvement with emphasis on wide hybridization. Gainesville, 1995. 152p. Tese (Ph.D) - University of Florida 
MOURÃO FILHO, F.A.A.; GROSSER, J.W. Callus induction from Citrus relatives: an alternative source of protoplasts for somatic hybridization experiments. Proceedings of the Florida State Horticultural Society, v.105, p.52-56, 1992.

MOURÃO FILHO, F.A.A.; GMITTER JUNIOR, F.; GROSSER, J.W. New tetraploid breeding parents for triploid seedless citrus cultivar development. Fruit Varieties Journal, v.50, n.2, p.76-80.1996.

MULLER, G.W.; COSTA, A.S. Doenças causadas por vírus, viroses e similares em citros. In: RODRIGUEZ, o; VIÉGAS, F.; POMPEU JUNIOR, J.; AMARO, A.A. Citricultura brasileira. Campinas: Fundação Cargill, 1991. v.2, p.735-762.

MULLER, G.W.; TARGON, M.L.P.N.; MACHADO, M.A. Trinta anos de uso do clone pré-iminizado de 'Pêra IAC' na citricultura paulista. Laranja, v.20, n.2, p.399-408,1999.

MURASHIGE, T.; TUCKER, D.P.H. Growth factor requirements of citrus tissue culture. In: CITRUS SYMPOSIUM, 1., Riverside, 1969. Proceedings. Riverside: University of California, 1969. p.1155-1161.

NAVARRO, L. Citrus tissue culture. In: FAO/NORWAY SYPOSIUM ON PLANT TISSUE CULTURE, TECHNOLOGY AND UTILIZATION, As Norway, 1984. Micropropagation of selected rootcrops, palms, citrus and ornamental species; proceedings. Rome: FAO, 1984. p.113-154. (FAO Plant Production and Protection Paper, 59). 
NAVARRO, L.; JUAREZ, J. Tissue culture techniques used in Spain to recover virus-free citrus plants. Acta Horticulturae, n.78, p.425-435, 1977.

NAVARRO, L.; JUAREZ, J.; BALLESTER, J.F.; PINA, J.A.; ORTEGA, C. Obtención de plantas nucleares livres de virus de diversas variedads de agrios del grupo Navel (Citrus sinensis Osbeck) por cultivos de óvulos in vitro. Anales del Instituto Nacional de Investigaciones Agronomicas, v.12, p.95-113, 1979.

NEVES, E.M. Economia da produção citrícola e efeitos alocativos. Preços Agrícolas, n.162, p.9-12, 2000.

NICKLE, T.C.; YEUNG, E.C. Futher evidence of a role for absciic acid in conversion of somatic embryos of Daucus carota. In Vitro Cell Development Biology, v.30, p.96-103, 1994.

OCHATT, S.J.; POWER, J.B. Plant regeneration from cultured protoplasts of higher plants. In: FOWLER, M.W.; WARREN, G.S.; MOO-YOUNG, M. (Ed.) Plant biotechnology: comprehensive biotechnology. Oxford: Pergamon Press, 1992. p.99-127

OCHATT, S.J.; COCKING, E.C.; POWER, J.B. Isolation, culture and plant regeneration of colt cherry (Prunus avium $x$ pseudocerasus) protoplasts. Plant Science, v.50, p.139-143, 1987.

OHGAWARA, T.; KOBAYASHI, S.; ISHII, S.; YOSHINAGA, K.; OIYAMA, I. Fertile fruit trees obtained by somatic hybridization: Navel orange (Citrus sinensis) and Troyer citrange (C. sinensis $x$ Poncirus trifoliata). Theoretical and Applied Genetics, v.81, p.141-143, 1991. 
OHGAWARA, T.; KOBAYASHI, S.; OHGWARA, E.; UCHIMIYA, H.; ISHII, S. Somatic hybrid plants obtained by protoplast fusion between Citrus sinensis and Poncirus trifoliata. Theoretical and Applied Genetics, v.71, p.1-4, 1985.

OLIVEIRA, R.P. Cultura de calos, células em suspensão e protoplastos de porta-enxertos de citros. Piracicaba, 1993. 117p. Dissertação (Mestrado)- Centro de energia Nuclear na Agricultura, Universidade de São Paulo.

OLIVEIRA, R.P.; MENDES, B.M.J.; TULMANN NETO, A. Obtenção e cultura de calos nucelares de limão Cravo, tangerina Cleópatra e Poncirus trifoliata. Revista Brasileira de Fiosiologia Vegetal, v.6, p.115-119, 1994a.

OLIVEIRA, R.P.; MENDES, B.M.J.; TULMANN NETO, A. Cultura de células em suspensão de dois porta-enxertos de citros. Revista Brasileira de Fiosiologia Vegetal, v.6, p.141-144, 1994b.

OLLITRAUT, P.; LURO, F. Amélioration des agrumes biotecnologie. Fruits, v.50, p.267-279, 1995.

PADMANABHAN, K.; CANTLIFFE, D.J.; HARRELL, R.C. A comparison of shoot-forming and non-shoot-forming somatic embryos of sweet potato [/pomoea batatas (L.) Lam.] using computer vision and histological analyses. Plant Cell Reports, v.17, p.685-692, 1998.

PARROT, W.A.; MERKLE, S.A.; WILLIAMS, E.G. Somatic embryogenesis: potencial for use in propagation and gene transfer systems. In: 
MURRAY, D.R. (Ed.) Advanced methods in plant breeding and biotechnology. Wallingford: CAB International, 1992. p.158-200.

PASQUAL, M. Regeneração de plantas in vitro e radiossensitividade de tecidos nucelares de citros. Piracicaba, 1985. 106p. Tese (Doutorado) - Escola Superior "Luiz de Queiroz", Universidade de São Paulo.

PASQUAL, M.; ANDO, A.; CROCOMO, O.J. Influência de reguladores de crescimento sobre a embriogênese in vitro de nucelos de Citrus sinensis cv. Valência. Pesquisa Agropecuária Brasileira, v.23, p.255-259, 1988.

PASSOS, I.; APPEZZATO-DA-GLÓRIA, B.; VIEIRA, M.L.C. Embryogenic responses of Vitis spp.: effects of genotype and polyvinylpyrolidone. Vitis, v.38, p.47-50, 1999.

PASSOS, O.S.; CUNHA SOBRINHO, A.P. DA; COELHO, Y. DA S. Melhoramento da Iaranja Bahia, Citrus sinensis (L.) Osbeck. In: CONGRESSO BRASILEIRO DE FRUTICULTURA, 2., Viçosa, 1973. Anais. Viçosa, 1973. v.1, p.257-271.

PEÑA, L.; CERVERA, M.; JUÁREZ, J.; NAVARRO, A.; PIÑA, J.A.; NAVARRO, L. Genetic transformation of lime (Citrus aurantifolia Swing.): factors affecting transformation and regeneration. Plant Cell Reports, v.16, p.731-737, 1997.

PEÑA, L.; CERVERA, M.; JUÁREZ, J.; NAVARRO, A.; PIÑA, J.A.; DURÁN-VILA, N.; NAVARRO, L. Agrobacterium-mediated 
transformation sweet orange and regeneration of transgenic plants. Plant Cell Reports, v.14, p.616-619, 1995a.

PEÑA, L.; CERVERA, M.; JUÁREZ, J.; ORTEGA, C.; PIÑA, J.A.; DURÁNVILA, N.; NAVARRO, L. High efficiency Agrobacterium-mediated transformation and regeneration of citrus. Plant Science, v.104, p.183-191, 1995b.

PEREZ, R.M.; GALIANA, A.M.; NAVARRO, L.; DURAN-VILA, $\quad \mathbf{N}$. Embryogenesis in vitro several citrus species and cultivars. Journal of Horticultural Science \& Biotechnology, v.73, n.6, p.796-802, 1998.

POMPEU JUNIOR, J. Porta-enxertos. In: RODRIGUEZ, O.; VIEGAS, F.; POMPEU JUNIOR, J.; AMARO, A.A. Citricultura brasileira. 2.ed. Campinas: Fundação Cargill, 1991. v.1, p.265-280.

POWER, J.B.; CUMMING, S.E.; COCKING, E.C. Fusion of isolated plant protoplasts. Nature,v.225, p.1016-1018, 1970.

RAMALHO, M.; SANTOS, J.B.; PINTO, C.B. Genética na agropecuária. Lavras: Editora Globo, 1990. p.249-273.

RAHMAN, M. M.M; NITO, N. Phylogenetic relationships in the kunkat (Fortunela) as revealed by isozyme analy PEÑA, L.; CERVERA, M.; JUÁREZ, J.; NAVARRO, A.; PIÑA, J.A.; NAVARRO, L. Genetic transformation of lime (Citrus aurantifolia Swing.): factors affecting transformation and regeneration. Plant Cell Reports, v.16, p.731-737, 1997.

sis. Scientis Horticulturae, v.57, p.17-28, 1994. 
RANGA SWAY, N.S. Culture of nucelar tissue of Citrus in vitro. Experientia, v.14, p.111-112, 1958.

RANGA SWAY, N.S. Morphogenetic response of Citrus ovules to growth adjuvants in culture. Nature, v.183, p.735-736, 1959.

RANGAN, T.S.; MURASHIGE, T.; BITTERS, W.P. In vitro initiation of nucellar embryos imonoembryogenesis citrus. HortScience, v.3, p.226-227, 1968.

RANGAN, T.S.; MURASHIGE, T.; BITTERS, W.P. In vitro studies of zygotic and nucellar embryogenesis in citrus. In: INTERNATIONAL CITRUS SYMPOSIUM, 1., Riverside, 1969. Proceedings. Riverside: University of California, 1969. v.1, p.225-229.

RODRIGUEZ, A.P.M.; WETZSTEIN, H.Y. The effect of auxin type and concentration on pecan (Carya illinoinensis) somatic embryo morphlogy and subsequent conversion into plants. Plant Cell Reports, v.13, p.607-611, 1994.

RODRIGUEZ, A.P.M.; WETZSTEIN, H.Y. A morphological and histological comparison of the initiation and development of pecan (Carya illinoinesis) somatic embriogenic cultures induced with naphthaleneacetic acid or 2,4-diclorophenoxyacetic acid. Protoplasma, v 204, p.71-83, 1998.

RODRIGUEZ, O. Clone novo na citricultura. O Agronômico, v.8, p.5-6, 1956. 
ROSSETI, V. Doenças dos citros. In: RODRIGUEZ, Z.O.; VIÉGAS, F.; POMPEU JUNIOR, J.; AMARO, A.S. (Ed.) Citricultura brasileira. 2.ed. Campinas: Fundação Cargil, 1991. v.2, p.668-714.

SAITO, W.; OHGAWSRA, T.; SHIMIZU, J.; ISHII, S. Acid citrus somatic hybrids between sudachi (Citrus sudachi Hort. ex Shirai) and lime ( $C$. aurantifolia Swing.) produced by eletrofusion. Plant Science, v.77, p.125-130, 1991.

SAITO, W.; OHGAWARA, T.; SHIMIZU, J.; ISHII, S.; KOBAYASHI, S. Citrus cybrid regenation following cell fusion between nucellar cells and mesophyll cells. Plant Science, v.88, p.195-201, 1993.

SALIBE, A.A. Citros: Doenças de vírus e similares. Laranja, v.12, n.2, p.365-380, 1991.

SALIBE, A.A.; MOREIRA, C.S.; MOREIRA, S. Production, selection ind commercial use of citrus nucellar clones in Brazil. Proceedings of the International Society of Citriculture, v.1, p.91-96, 1984.

SALISBURY, F.B.; ROSS, C.W. Crecimiento y desarrollo. In: SALISBURY, F.B.; ROSS, C.W. (Ed.) Fisiologia vegetal. México: Grupo Editorial Iberoamericana, 1994. cap.4, p.71-100.

SAS INSTITUTE Inc. SAS/STAT. Uner's guide, Version 6.03. Cary: SAS Institute, 1988.

SCHENK, R.U.; HILDEBRANT, A.C. Role of the cell wall in the ability of tabacco protoplasts to from callus. Planta, v.135, p.177-181, 1977. 
SHAIN, E.A. Totpotency of tomato protoplasts. Theoretical and Applied Genetics, v.69, p.235-240, 1985.

SHARP, W.R. The physiology of in vitro asexual embryogenesis. Horticultural Reviews, v.2, p.268-310, 1980.

SHILLITO, R.D.; PASZKOWSKI, J., POTRYKUS, I. Agarose plating and a bed culture techinique enable and stimulate development of protoplast-derived colonies in a number of plant species. Plant Cell Reports, v.2, p.244-247, 1983.

SHOEMAKER, R.C.; AMBERGER, L.A.; PALMER, R.G.; OBLESBLY, L.; RANCH, J.P. Effect of 2-4-diclorophexyacetic acid concentration on somatic embryogenesis and heritable variation in soybean (Glycine max. (L.) Merr.). In Vitro Celular e Developmental Biology, v.27, p. 84-88, 1991.

SILVEIRA, J.A.M. Resumo informativo da cultura dos citros no estado de SãoPaulo. Piracicaba, 1996. 57p. Monografia (Graduação) - Escola Superior de Agricultura "Luiz de Queiroz", Universidade de São Paulo.

SOBRINHO, J.T. Propagação dos citros. In: RODRIGUEZ, Z.O.; VIÉGAS, F.; POMPEU JUNIOR, J.; AMARO, A.S. (Ed.) Citricultura brasileira. Campinas: Fundação Cargil, 1991. v.1, p.281-301.

SONG, W.S.; CHO, H.M.; PARK, J.H. Plant regeneration in dangyooza (Citrus grandis Osbeck) through somatic embryogenesis. 1- Effect of plant growth regulators on embryogenic callus induction and somatic embryogenesis. Research Reports of the Rural Development Administration, Biotechnology, v.33, n.2, p.14-21, 1991. 
SOOST, R.K.; CAMERON, J.W. Citrus. In: JANICK, J.; MOORE, J.N. (Ed.) Advances in fruit breeding. West Lafayette: Purdue University Press, 1975. p.507-540.

SPIEGEL-ROY, P.; KOCHBA, J. Embryogenesis in Citrus tissue culture. Advances in Biochemical Engineering, v.16, p.27-48, 1980.

SUNDENBERG, E.; GLIMELIUS, K. Effects of parental ploidy level and genetic divergence on chromosome elimination and choroplast segregation in somatic hybrids within Brassicaceae. Theoretical and Applied Genetics, v.83, p.81-88, 1991.

SUTCLIFFE, J.F. Transpiração. In: SUTCLIFFE, J.F. (Ed.) As plantas e a água. São Paulo: Editora da Universidade de São Paulo, 1980. cap.5, p.77-93.

SUZUKI, D.T.; GRFFITHS, A.J.; LEWONTIN, R.C. An introduction to genetic analysis. New York: W.H. Freeman and Company, 1981. $911 p$.

SWINGLE, W.T.; REECE, P.C. The botany of citrus and its wild relatives. In: REUTHER, W.; WEBBER, H.J.; BATCHELOR (Ed.) The citrus industry. Berkeley: University of California Press, 1967. p.190-430.

TEÓFILO SOBRINHO, J.; POMPEU JUNIOR, J.; RODRIGUEZ, O.; FIGUEIREDO, J.O.; BARBIN, D. Melhoramento de clones de laranjeira 'Pêra' no Estado de São Paulo. In: CONGRESSO BRASILEIRO DE FRUTICULTURA, 2., Salvador, 1978. Anais. Salvador, 1978. p.111-116. 
TOMAZ, M.T. Embriogênese somática em Citrus spp. Piracicaba, 2000. 78p. Dissertação (Mestrado) - Escola Superior de Agricultura "Luiz de Queiroz, Universidade de São Paulo.

TULMANN NETO, A.; POMPER JUNIOR, J.; CERAVOLO, L.; ROSSI, A. C.; MENTEN, J.O.M. Avanços no melhoramento de laranja visando resistência ao cancro e outras características através de mutações induzidas. Laranja, v.12, p.435-447, 1991.

TUSA, N.; GROSSER, J.W.; GMITTER JUNIOR F.G. Plant regeneration of 'Valência' sweet orange, 'Femminelo' lemon and the interespecific somatic hybrid following protoplast fusion. Journal of the American Society for Horticultural Science, v.115, n.6, p.1043-1046, 1990.

VARDI, A. Protoplast derived from different citrus species and cultivars. Proceedings of the International Society of Citriculture, v.1, p.149152, 1981.

VARDI, A.; GALUN, E. Recent advances in protoplast culture of horticultural crops: Citrus. Scientia Horticulturae, v.37, p.217-230, 1988.

VARDI, A.; GALUN, E. Isolation and culture of citrus protoplasts. In: BAJAJ, Y.P.S. (Ed.) Plant protoplasts and genetic engeneering I. Berlin: Springer-Verlag, 1989. cap.2, p.147-159. (Biotechnology in Agriculture and Forestry, 8). 
VARDI, A.; SPIEGEL-ROY, P. Plant regeneration from Citrus protoplasts: Variability in methodological requirements among cultivars and species. Theoretical and Applied Genetics, v.62, p.171-176, 1982.

VARDI, A.; BREIMAN, A.; GALUN, E. Citrus cybrids: producrion by donorrecipient protoplast-fusion and verification by mitochondrial-DNA restriction profiles. Theoretical and Applied Genetics, v.75, p.5158, 1987.

VARDI, A.; HUTCHISON, D.J.; GALUN, E. A protoplast-to-tree system in Microcitrus based on protoplasts derived from a sustained embryogenic callus. Plant Cell Reports, v.5, p.412-414, 1986.

VARDI, A.; SPIEGEL-ROY, P.; GALUN, E. Citrus cell culture: isolation of protoplasts, plating densities, effect of mutagens and regeneration of embryos. Plant Science Letters. v.4, p.31-36, 1975.

VARDI, A.; SPIEGEL-ROY, P.; GALUN, E. Plant regeneration from Citrus protoplasts: variability in methodological requirements among cultivars and species. Theoretical and Applied Genetics, v.62, p.171-176, 1982.

VARDI, A.; GONEN, P.A.; SHANI, S.F.; BLEICHMAN, S.; GALUN, E. Protoplast fusion mediated transfer of organelles from Microcitrus into Citrus and regeneration of novel alloplasmic trees. Theoretical and Applied Genetics, v.78, p.741-747, 1989.

VASIL, I.K.; VASIL, V. Isolation and culture of protoplasts. International Review of Cytology, Sup.11B, p.1-9, 1980. 
VIEIRA, M.L.C. Estudo citotaxionômico de espécies brasileiras do gênero Stylozanthes Sw. Piracicaba, 1988. 135p. Tese (Doutorado) Escola Superior de Agricultura "Luiz de Queiroz", Universidade de São Paulo.

VILARINHOS, A.D.; VIANA, C.E.P.; SOARES FILHO, W.S.;NICKEL, O.; OLIVEIRA, R.P. Marcadores RAPD na avaliação da diversidade genética e identificação de híbridos interespecíficos de citros. Revista Brasileira de Fruticultura, v.22, n.1, p.14-19, 2000.

VU, J.C.V.; NIEDZ, R.P.; YELENOSKY, G. Glycerol stimulation of chlorophyll synthesis, embryogenesis, and carboxylation and sucrose metabolism enzymes in nucellar callus of "Hamlin" sweet orange. Plant Cell, Tissue and Organ Culture, v.33, p.75-80, 1993.

WETZSTEIN, H.Y.; BAKER, C.M. The relationship between somatic embryo morphology and conversion in peanut (Arachis hypogae L.). Plant Science, v.92, p.81-89, 1993.

WILLIAMS, E.G.; MAHESWARAN, G.M. Somatic embryogenesis: factors influencing coordinated behaviour of cells as an embryogenic groups. Annals of Botany, v.57, p.443-462, 1986.

ZANOL, G.C.; OLIVEIRA, R.P.; SOARES FILHO, W.S.;SOUZA, G.C. Ajuste de metodologias para a obtenção de calos nucelares embriogênicos e cultivo in vitro de "seedlings" de citros. In: ENCONTRO BRASILEIRO DE BIOTECNOLOGIA VEGETAL, 2., Gramado, 1997. Resumos. Gramado, 1997. p.178. 
ZIMMERMAN, J.L. Somatic embryogenesis: A model for early 'development in higher plants. The Plant Cell, v.5, p.1411-1423, 1993. 


\section{ANEXO}

Composição dos meios de cultura:

1. Soluções estoque de macronutrientes de MT (50X) g. $\begin{array}{ll}\mathrm{NH}_{4} \mathrm{NO}_{3} & 82.5\end{array}$

$\mathrm{KNO}_{3} \quad 95.0$

$\mathrm{MgSO}_{4} * 7 \mathrm{H}_{2} \mathrm{O} \quad 18.5$

$\begin{array}{ll}\mathrm{KH}_{2} \mathrm{PO}_{4} \text { (monobásico) } & 7.5\end{array}$

$\begin{array}{ll}\mathrm{K}_{2} \mathrm{HPO}_{4} \text { (dibásico) } & 1.0\end{array}$

2. Soluções estoque de micronutrientes de MT (100X) g. $\mathrm{L}^{-1}$ $\begin{array}{ll}\mathrm{H}_{3} \mathrm{BO}_{3} & 0.62\end{array}$

$\mathrm{MnSO}_{4} * \mathrm{H}_{2} \mathrm{O} \quad 1.68$

$\mathrm{ZNSO}_{4} * 7 \mathrm{H}_{2} \mathrm{O} \quad 0.86$

$\begin{array}{ll}\mathrm{KI} & 0.025\end{array}$

$\mathrm{Na}_{2} \mathrm{MoO}_{4} * 2 \mathrm{H}_{2} \mathrm{O} \quad 0.0025$

$\mathrm{CuSO}_{4} * 5 \mathrm{H}_{2} \mathrm{O} \quad 0.0025$

$\mathrm{CoCl}_{2} * 6 \mathrm{H}_{2} \mathrm{O}$

3. Soluções estoque de ferro de MT (200X) g.

$\begin{array}{ll}\mathrm{Na}_{2} \text { EDTA } & 7.45\end{array}$

$\mathrm{Fe}_{2} \mathrm{SO}_{4} * 7 \mathrm{H}_{2} \mathrm{O} \quad 5.57$

4. Soluções estoque de vitaminas de MT (100X) g. $\mathrm{L}^{-1}$

$\begin{array}{ll}\text { Inositol } & 10.0\end{array}$

$\begin{array}{ll}\text { Tiamina-HCL } & 1.0\end{array}$

$\begin{array}{ll}\text { Piroxidina } & 1.0\end{array}$

ácido nicotínicoglicina $\quad 0.5$

$\begin{array}{ll}\text { Glicina } & 0.2\end{array}$ 
5. Soluções estoque de cálcio (66X)

g. $\mathrm{L}^{-1}$

$\mathrm{CaCl}_{2} * 2 \mathrm{H}_{2} \mathrm{O}$

6.Soluções estoque de macronutrientes de $\mathrm{BH}_{3}$ (100X)

g. $L^{-1}$

$\mathrm{MgSO}_{4}$

37.0

$\mathrm{KH}_{2} \mathrm{PO}_{4}$

$\mathrm{K}_{2} \mathrm{HPO}_{4}$

2.0

$\mathrm{KCl}$

150.0

7. Solução estoque de A multivitaminas de $\mathrm{BH}_{3}$ (100X)

g. $100 \mathrm{~mL}^{-1}$

Pantotenato

0.05

Ácido ascóbico

0.1

Cloreto de colina

0.05

Ácido p-Aminobenzóico

0.001

Ácido fólico

0.002

Riboflavina

0.01

Biotina

0.001

8. Solução estoque de $\mathrm{B}$ multivitaminas de $\mathrm{BH}_{3}$ (100X)

g. $L^{-1}$

Retinol (vitamina A)

0.001

Cholecalciferol (vitamina $D_{3}$ )

0.001

Vitamina $B_{12}$

0.002

9. Solução estoque de $\mathrm{KI}$ e $\mathrm{BH}_{3}(100 \mathrm{X}$

g. $L^{-1}$

$\mathrm{KI}$

0.075

10. Solução estoque de ácidos orgânicos $\mathrm{BH}_{3}$ (150X)

g. $L^{-1}$

Piruvato de sódio

0.1

Ácido cítrico

0.2

Ácido málico

0.2

Ácido fumárico

0.2 
11. Solução estoque de açúcares $\mathrm{BH}_{3}(100 \mathrm{X})$

g. $L^{-1}$

Frutose

2.5

Ribose

2.5

Xilose

2.5

Manose

2.5

Ramose

2.5

Celobiose

2.5

Galactose

2.5

Manitol

2.5

12. Solução estoque 1 de sais CPW

g. $L^{-1}$

$\mathrm{KH}_{2} \mathrm{PO}_{4}$

0.2720

$\mathrm{KNO}_{3}$

1.0000

$\mathrm{MgSO}_{4}$

2.5000

$\mathrm{KI}$

0.0016

$\mathrm{CuSO}_{4}$

0.00025

13. Solução estoque 2 de sais CPW

g. $L^{-1}$

$\mathrm{CaCl}_{2}$

1.5

\section{Meios de Cultura}

1.EME (0.145M)

Estoque dos macronutrientes de MT (50X)

$20 \mathrm{~mL} \cdot \mathrm{L}^{-1}$

Estoque dos micronutrientes de MT (100X)

$10 \mathrm{~mL} \cdot \mathrm{L}^{-1}$

Estoque de vitaminas de MT (100X)

$10 \mathrm{~mL} \cdot \mathrm{L}^{-1}$

Estoque de cálcio de MT (66X)

$15 \mathrm{~mL} \cdot \mathrm{L}^{-1}$

Estoque de ferro de MT (66X)

$5 \mathrm{~mL} \cdot \mathrm{L}^{-1}$

Sacarose

$50 \mathrm{~g} \cdot \mathrm{L}^{-1}$

Extrato de malte

$0.5 \mathrm{~g} \cdot \mathrm{L}^{-1}$

Ágar

$8.0 \mathrm{~g} . \mathrm{L}^{-1}$

Ajustar o $\mathrm{pH}$ para $5.8 \mathrm{com} \mathrm{KOH}$ 
2. $\mathrm{H}+\mathrm{H}$

Estoque dos macronutrientes de MT (50X)

$10 \mathrm{~mL} \cdot \mathrm{L}^{-1}$

Estoque dos micronutrientes de MT (100X)

$10 \mathrm{~mL} \cdot \mathrm{L}^{-1}$

Estoque de macronutrientes de $\mathrm{BH}^{3}$ (100X)

$5 \mathrm{~mL} \cdot \mathrm{L}^{-1}$

Estoque de vitaminas de MT (100X)

$10 \mathrm{~mL} \cdot \mathrm{L}^{-1}$

Estoque de cálcio de MT (66X)

$15 \mathrm{~mL} . \mathrm{L}^{-1}$

Estoque de ferro de MT (66X)

$5 \mathrm{~g} \cdot \mathrm{L}^{-1}$

Sacarose

$50 \mathrm{~g} \cdot \mathrm{L}^{-1}$

Extrato de malte

$0.5 \mathrm{~g} \cdot \mathrm{L}^{-1}$

Glutamina

$1.55 \mathrm{~g} \cdot \mathrm{L}^{-1}$

Ágar

$8.0 \mathrm{~g} \cdot \mathrm{L}^{-1}$

Ajustar o $\mathrm{pH}$ para $5.8 \mathrm{com} \mathrm{KOH}$

\section{Meio de Cultura CPW}

Adicional $1 \mathrm{~mL}$ de cada estoquel $100 \mathrm{~mL}$ de meio de cultura

Ajustar o $\mathrm{pH}$ para $5.8 \mathrm{com} \mathrm{KOH}$

Para CPW com $13 \%$ de manitol, adicionar $13 \mathrm{~g}$ de manitol $/ 100 \mathrm{~mL}$

Para CPW com $25 \%$ de manitol, adicionar $25 \mathrm{~g}$ de sacarose $/ 100 \mathrm{~mL}$

\section{Solução de PEG}

Polietilenoglicol $(P M=1450)$

$40 \mathrm{~g} \cdot \mathrm{L}^{-1}$

$\mathrm{CaCl}_{2} * 2 \mathrm{H}_{2} \mathrm{O}$

$0.97 \mathrm{~g} . \mathrm{L}^{-1}$

Glucose

$5.41 \mathrm{~g} . \mathrm{L}^{-1}$

Ajustar o pH para $6.0 \mathrm{com} \mathrm{KOH}$

Esterilizar em filtro de $0.2 \mu$ 


\section{RMAN}

Estoque dos macronutrientes de MT (50X)

$10 \mathrm{~mL} \cdot \mathrm{L}^{-1}$

Soluções estoque de micronutrientes de MT (100X)

$5 \mathrm{~mL} \cdot \mathrm{L}^{-1}$

Soluções estoque de vitaminas de MT (100X)

$5 \mathrm{~mL} \cdot \mathrm{L}^{-1}$

Soluções estoque de cálcio de MT (66X)

$15 \mathrm{~mL} \cdot \mathrm{L}^{-1}$

Soluções estoque de ferro de MT (200X)

$5 \mathrm{~mL} \cdot \mathrm{L}^{-1}$

Estoque de ANA (279.3 mg/l)

$72 \mu \mathrm{L} . \mathrm{L}^{-1}$

Carvão ativado

$0.5 \mathrm{~g} \cdot \mathrm{L}^{-1}$

Sacarose

25 g. $\mathrm{L}^{-1}$

Ágar

$8 \mathrm{~g} . \mathrm{L}^{-1}$ 